OPEN ACCESS

Edited by:

Jess Melbourne-Thomas, Oceans and Atmosphere (CSIRO),

Australia

Reviewed by:

Jody Renae Reimer,

The University of Utah, United States

Vivitskaia J. D. Tulloch,

The University of British Columbia,

Canada

*Correspondence:

Sophie Bestley

sophie.bestley@utas.edu.au

†These authors have contributed equally to this work

Specialty section:

This article was submitted to

Conservation and Restoration

Ecology,

a section of the journal

Frontiers in Ecology and Evolution

Received: 29 May 2020 Accepted: 17 September 2020

Published: 04 November 2020

Citation:

Bestley S, Ropert-Coudert Y, Bengtson Nash S, Brooks CM, Cotté C, Dewar M, Friedlaender AS,

Jackson JA, Labrousse $S$,

Lowther AD, McMahon CR,

Phillips RA, Pistorius P, Puskic PS, Reis $A O A$, Reisinger RR, Santos $M$,

Tarszisz E, Tixier $P$, Trathan PN,

Wege $M$ and Wienecke B (2020)

Marine Ecosystem Assessment

for the Southern Ocean: Birds

and Marine Mammals in a Changing Climate. Front. Ecol. Evol. 8:566936.

doi: $10.3389 /$ fevo.2020.566936

\section{Marine Ecosystem Assessment for the Southern Ocean: Birds and Marine Mammals in a Changing Climate}

Sophie Bestley ${ }^{1 * t}$, Yan Ropert-Coudert ${ }^{2 t}$, Susan Bengtson Nash ${ }^{3}$, Cassandra M. Brooks ${ }^{4}$, Cédric Cotté5, Meagan Dewar6,7, Ari S. Friedlaender 8 , Jennifer A. Jackson ${ }^{9}$, Sara Labrousse ${ }^{10}$, Andrew D. Lowther ${ }^{11}$, Clive R. McMahon ${ }^{1,12,}$ Richard A. Phillips ${ }^{9}$, Pierre Pistorius ${ }^{13}$, Peter S. Puskic ${ }^{1,14}$, Ana Olivia de A. Reis ${ }^{15}$, Ryan R. Reisinger ${ }^{8}$, Mercedes Santos ${ }^{16}$, Esther Tarszisz ${ }^{17}$, Paul Tixier ${ }^{18}$, Philip N. Trathan ${ }^{9}$, Mia Wege ${ }^{19,20}$ and Barbara Wienecke ${ }^{21}$

${ }^{1}$ Institute for Marine and Antarctic Studies, University of Tasmania, Hobart, TAS, Australia, ${ }^{2}$ Centre d'Etudes Biologiques de Chizé, UMR 7372 CNRS-La Rochelle Université, Villiers-en-Bois, France, ${ }^{3}$ Environmental Futures Research Institute, Griffith University, Nathan, QLD, Australia, ${ }^{4}$ Environmental Studies Program, University of Colorado Boulder, Boulder, CO, United States, ${ }^{5}$ Sorbonne Université UMR 7159 CNRS-IRD-MNHN, LOCEAN-IPSL, Paris, France, ${ }^{6}$ School of Science, Psychology and Sport, Federation University Australia, Berwick, VIC, Australia, ${ }^{7}$ School of Life and Environmental Sciences, Deakin University, Burwood, VIC, Australia, ${ }^{8}$ Institute of Marine Sciences, University of California, Santa Cruz, Santa Cruz, CA, United States, ${ }^{9}$ British Antarctic Survey, Natural Environment Research Council, Cambridge, United Kingdom, ${ }^{10}$ Woods Hole Oceanographic Institution, Woods Hole, MA, United States, ${ }^{11}$ Norwegian Polar Institute, Tromsø, Norway, ${ }^{12}$ IMOS Animal Tagging, Sydney Institute of Marine Science, Mosman, NSW, Australia, ${ }^{13}$ Institute for Coastal and Marine Research, Department of Zoology, Nelson Mandela University, Port Elizabeth, South Africa, ${ }^{14}$ Centre for Marine Socioecology, University of Tasmania, Hobart, TAS, Australia, ${ }^{15}$ Laboratório de Micropoluentes Orgânicos Jan Japenga, Instituto de Biofísica Carlos Chagas Filho, Universidade Federal do Rio de Janeiro, Rio de Janeiro, Brazil, ${ }^{16}$ Departamento Biología de Predadores Tope, Instituto Antártico Argentino, Buenos Aires, Argentina, ${ }^{17}$ Sydney Institute of Marine Science, Mosman, NSW, Australia, ${ }^{18}$ School of Life and Environmental Sciences, Deakin University, Geelong, VIC, Australia, ${ }^{19}$ Gateway Antarctica, University of Canterbury, Christchurch, New Zealand, ${ }^{20}$ Department of Zoology and Entomology, University of Pretoria, Pretoria, South Africa, ${ }^{21}$ Australian Antarctic Division, Department of Agriculture, Water and the Environment, Kingston, TAS, Australia

The massive number of seabirds (penguins and procellariiformes) and marine mammals (cetaceans and pinnipeds) - referred to here as top predators - is one of the most iconic components of the Antarctic and Southern Ocean. They play an important role as highly mobile consumers, structuring and connecting pelagic marine food webs and are widely studied relative to other taxa. Many birds and mammals establish dense breeding colonies or use haul-out sites, making them relatively easy to study. Cetaceans, however, spend their lives at sea and thus aspects of their life cycle are more complicated to monitor and study. Nevertheless, they all feed at sea and their reproductive success depends on the food availability in the marine environment, hence they are considered useful indicators of the state of the marine resources. In general, top predators have large body sizes that allow for instrumentation with miniature datarecording or transmitting devices to monitor their activities at sea. Development of scientific techniques to study reproduction and foraging of top predators has led to substantial scientific literature on their population trends, key biological parameters, migratory patterns, foraging and feeding ecology, and linkages with atmospheric or oceanographic dynamics, for a number of species and regions. We briefly summarize 
the vast literature on Southern Ocean top predators, focusing on the most recent syntheses. We also provide an overview on the key current and emerging pressures faced by these animals as a result of both natural and human causes. We recognize the overarching impact that environmental changes driven by climate change have on the ecology of these species. We also evaluate direct and indirect interactions between marine predators and other factors such as disease, pollution, land disturbance and the increasing pressure from global fisheries in the Southern Ocean. Where possible we consider the data availability for assessing the status and trends for each of these components, their capacity for resilience or recovery, effectiveness of management responses, risk likelihood of key impacts and future outlook.

Keywords: marine ecosystem assessment, marine predators, climate change, fisheries interactions, conservation management, Antarctic

\section{INTRODUCTION}

The massive number of seabirds and marine mammals hereafter referred to as top predators ${ }^{1}$ - is one of the most conspicuous and iconic components of the Antarctic and Southern Ocean (Figure 1; Ropert-Coudert et al., 2014). Some species solely inhabit the polar region, adapted to survive and thrive year-round in this highly seasonal environment, such as the emperor penguin (Aptenodytes forsteri) famous for breeding on the ice during the austral ${ }^{2}$ winter (Stonehouse, 1952). Others are based on the scattered subantarctic islands, and commute between prey patches at sea and their breeding sites, sometimes covering extraordinary distances to do so, like the wandering albatross (Diomedea exulans). Still other populations, notably baleen whale species such as the humpback whale (Megaptera novaeangliae), undertake mass migrations poleward to capitalize on the high marine productivity during the spring and summer periods. These migratory movements connect the apparently isolated Southern Ocean environment with the temperate and tropical regions (see Murphy et al., to be published in this research topic), and in some cases even pole-to-pole, as in the case of the Arctic tern (Sterna paradisaea) (Egevang et al., 2010).

Rapid climate-related change is already manifesting in the physical environment and biological dynamics of the Southern Ocean (high confidence) (Meredith et al., 2019; Rogers et al., 2020). Within this apparently remote region, seabirds and marine mammals are also increasingly influenced by other human-related impacts (e.g., Erbe et al., 2019; Rodríguez et al., 2019; Ropert-Coudert et al., 2019). While relatively well-studied compared to other ecosystem components, knowledge of marine predators is still biased by accessibility (e.g., land-based versus oceanic or pack-ice breeders, also cryptic deep divers), seasonality (primarily summer studies) and also in relation to age or lifehistory stages (e.g., paucity of knowledge on juvenile, nonbreeding individuals). Key trophic processes supporting oceanic and ice-related food webs are still being unraveled.

\footnotetext{
${ }^{1}$ Not all species covered here are top predators, some refer to these diverse taxa as "meso- and top-predators" but, for simplicity, we will use the term top predators throughout.

${ }^{2}$ Seasons referred to are austral seasons throughout.
}

The first Marine Ecosystem Assessment for the Southern Ocean (MEASO) is an activity of the IMBer-SCAR program Integrating Climate and Ecosystem Dynamics in the Southern Ocean. The primary aim of MEASO is to assess the risks to Southern Ocean marine ecosystems from climate change and related change processes. As a core MEASO contribution, this paper summarizes the vast literature on Southern Ocean seabirds (flying and diving) and marine mammals (fur and true seals, and baleen and toothed cetaceans) to present the current state of knowledge. We provide an overview of the key pressures, arising from natural and human causes, that these animals face at sea and on land, recognizing the overarching effect that environmental changes - driven by global climate change - have on the ecology of these species. We also evaluate direct and indirect interactions between marine predators and other key stressors including the impacts of historical harvesting, the increasing pressure from fisheries in the Southern Ocean, global pollution, disease and stress, and terrestrial disturbances.

Different Southern Ocean marine systems are affected by and respond to change in different ways. Effects on species' ecology, and their status and trends, are species-specific and variable depending on location. Yet all seabirds and marine mammals feed at sea, their fitness, survival and reproductive success depending on the food availability in the marine environment. Their dependency on lower trophic level prey, such as Antarctic krill (Euphausia superba) linked directly to primary productivity, makes them particularly sensitive to bottom-up environmental changes driven by climate change. Therefore, top predators are widely considered useful indicators integrating the state of marine resources (Hazen et al., 2019).

\section{DATA, METHODS AND TOOLS}

Quantitative knowledge of the ecology of Southern Ocean top predators has rapidly increased in recent decades, facilitated by: (1) more researchers visiting more Southern Ocean sites, often for longer periods; (2) new and cheaper methods, technologies and techniques for collecting and analyzing data (Figures 2, 3) recognition of the importance of long-term, longitudinal data sets by researchers and funding organizations. Concurrently, the 


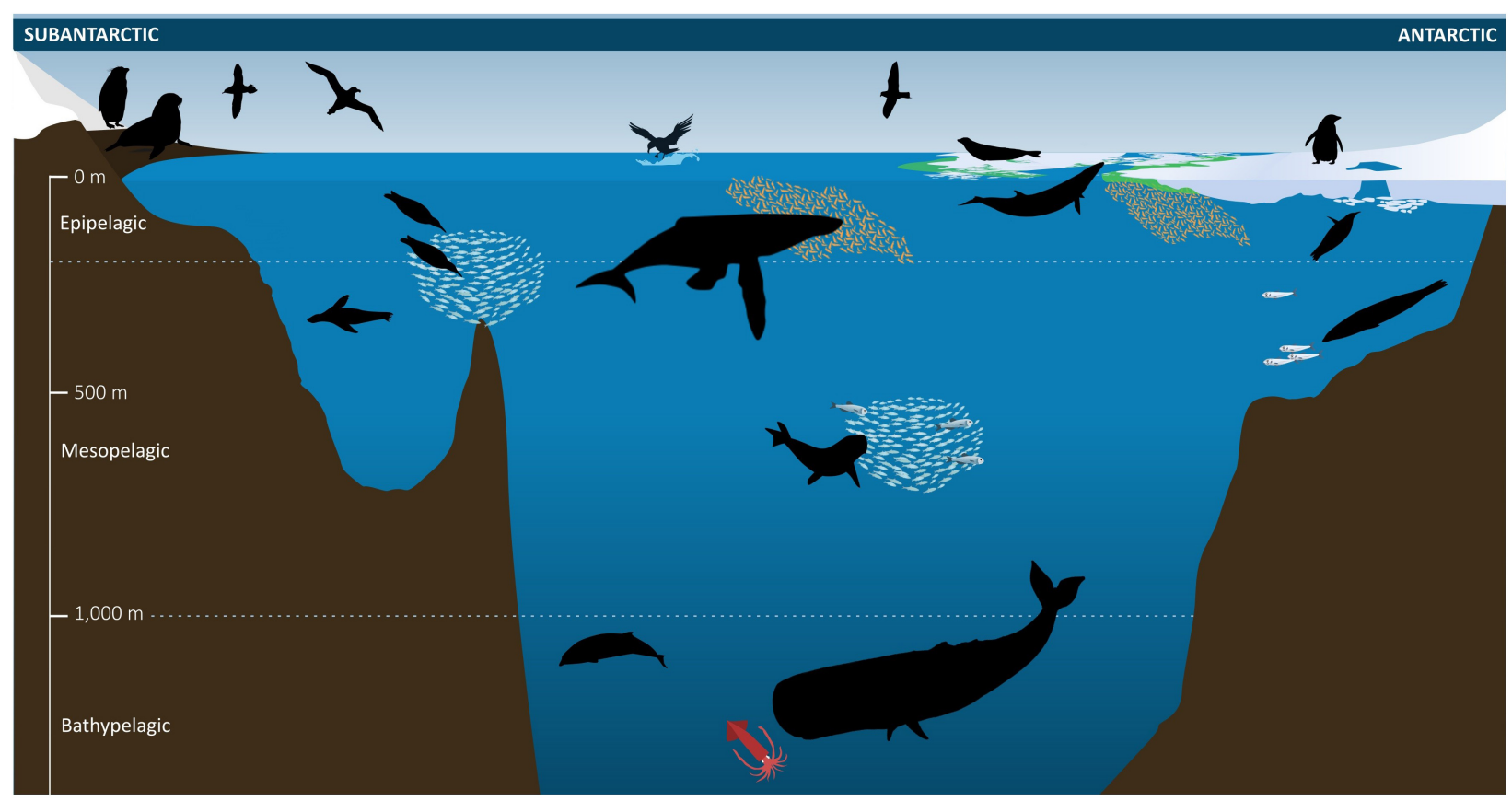

FIGURE 1 | Top predators (black) distribute throughout the Southern Ocean, horizontally, from the continent to the subantarctic islands, as well as vertically, with deep-diving species following their prey down to $>2000 \mathrm{~m}$.

role of freely accessible datasets has become widely recognized because of their contributions to diverse initiatives and because no single research group can obtain sufficient data over the spatial and temporal scales relevant to marine predators.

\section{Methods for Studying Marine Predators Population Monitoring}

At sea, shipboard observations are a traditional way of estimating the presence of given taxa. These observations may be from "platforms of opportunity" (e.g., regular transits to supply Antarctic stations, tourism vessels, commercial fishing vessels) or dedicated surveys. The observations are only available along ship tracks, but once collected in atlases (e.g., De Broyer et al., 2014) they can provide a holistic circumpolar view of the spatial distribution of top predators, albeit that the providence of observed individuals remains unknown. Further, survey data (ships, helicopters, fixed-wing aircrafts) can be used to estimate the abundance of species for a given area (e.g., Southwell et al., 2004; Williams et al., 2014) using density surface modeling methods relating observations to environmental covariates and estimating relative spatial distributions (e.g., Friedlaender et al., 2006).

On land, population counts via direct observation (e.g., Wege et al., 2016a), or aerial photography by aircraft (e.g., Weimerskirch et al., 2018), gliders (e.g., Kahl et al., 2010), drones (e.g., Goebel et al., 2015; Gray et al., 2019; Johnston, 2019) or kites (Delord et al., 2015) have been conducted at key sites for many decades. This yields detailed information on interannual patterns in abundance (e.g., Wege et al., 2016a) or intra-annual behavior, for example, phenology (e.g., Barbraud and Weimerskirch, 2006), but sites where counts are routinely conducted in longitudinal studies are spatially very limited. Remote observation might improve this (e.g., Southwell and Emmerson, 2015; Labrousse et al., 2019) and satellite surveillance can enable remote area assessment, at large scale and much reduced cost (LaRue and Knight, 2014). Counting animals from satellite images manually can be time-consuming and researchers are harnessing Deep Learning (e.g., Gonçalves et al., 2020) and citizen science through crowdsourcing, where online volunteers identify animals in the images (LaRue et al., 2019).

Long-term programs where individuals are marked or tagged enable trends in demographic parameters to be related to natural and anthropogenic environmental variation (e.g., Crawford and Cooper, 2003; Pardo et al., 2017). Increasingly, this information is linked to other aspects of a population or individual's ecology, such as genetic information (e.g., Forcada and Hoffman, 2014) or habitat use (e.g., Hindell et al., 2017).

\section{Animal-Borne Technologies}

Biotelemetry, where positional data are sent to a radio base (radio-telemetry) or relayed by satellite to a land-based platform (satellite telemetry), became widespread in the early 1990s, when it revealed the impressive distances that some species can cover (e.g., Jouventin and Weimerskirch, 1990). Satellite telemetry is now commonly used, especially to track species or life-history stages for which recapture is difficult or impossible, such as fledglings and juveniles (e.g., Orgeret et al., 2016). A key limitation is the quantity of data that can be transmitted to available satellites during the short surface times of diving animals. Nonetheless, thousands of individuals have been tracked 


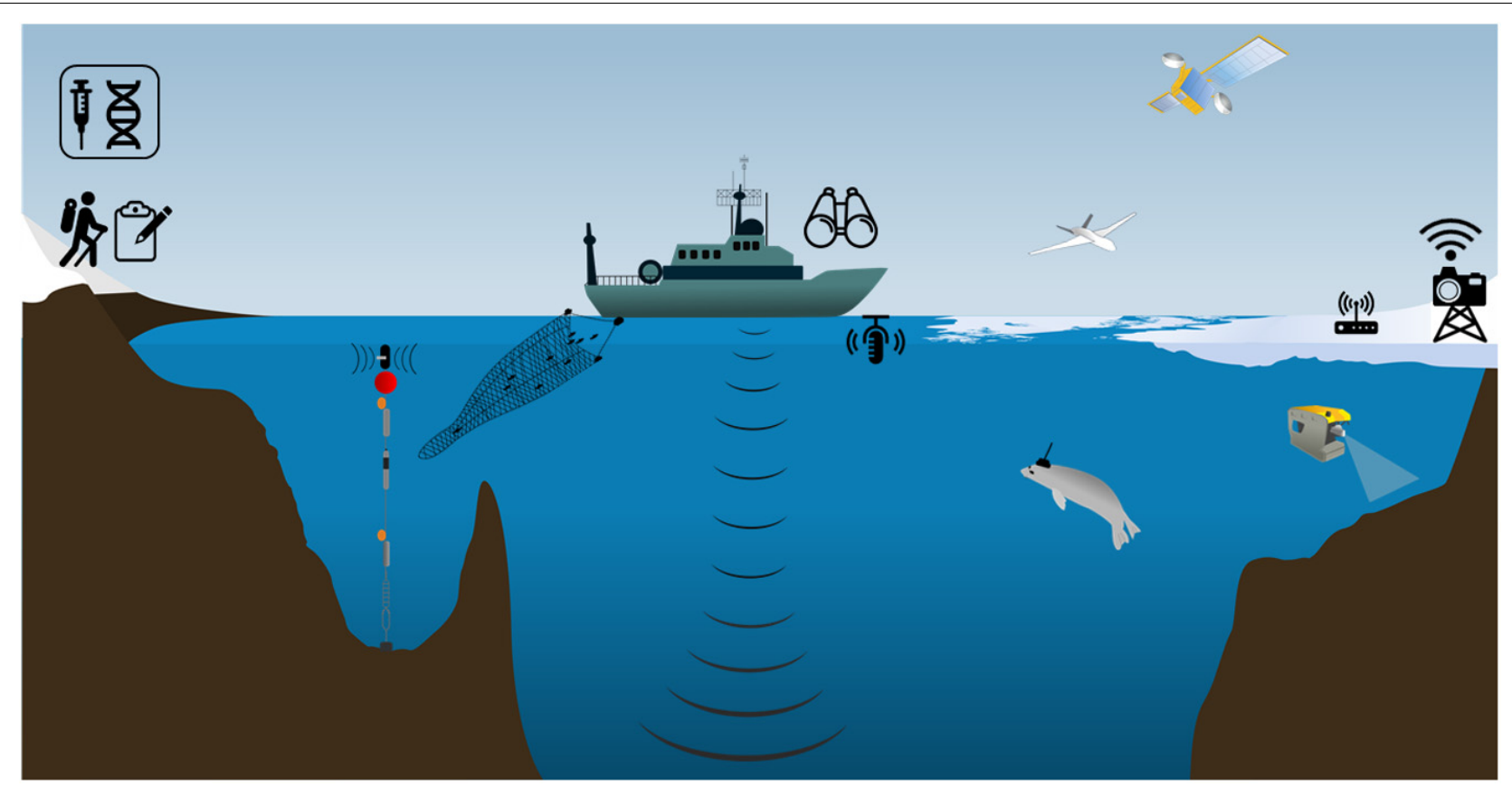

FIGURE 2 | Observational capacity, from traditional direct observations (visual population census, biological sampling) through to (semi-)automated processes (e.g., census counts via aerial photography from drones, satellite-based images and networks of remotely operating cameras). Vertical distribution is an important element constraining observational capacity. Underwater observations can be ship-based from active (e.g., echosounder) and passive (e.g., sonobuoy) acoustics, but are increasingly from technological advances in biotelemetry, automated underwater vehicles and underwater moorings (e.g., the Southern Ocean hydrophone network monitoring trends in whale abundance, distribution, and seasonal presence through use of passive acoustic techniques).

in the Southern Ocean using biotelemetry and bio-logging techniques (Ropert-Coudert et al., 2020), contributing to our understanding of the at-sea distribution and behavior of top predators (e.g., Reisinger et al., 2018; Hindell et al., 2020; Figure 3).

In comparison, archival bio-logging devices (RopertCoudert and Wilson, 2005; Ropert-Coudert et al., 2012) allow high quantities of continuous high-resolution streams of environmental and biological data to be recorded inside/outside animals and stored in onboard memory with ever-growing capacities. The disadvantage is the necessity to recapture individuals to retrieve devices. A new generation of devices combining the advantages of both biotelemetry and biologging (e.g., Heerah et al., 2019) has enabled cross-disciplinary studies, recording not only the georeferenced physiological and behavioral activity of animals, but also enabling measures of in situ physical parameters of the environment directly surrounding the animal. International programs like the Marine Mammals Exploring the Oceans Pole to Pole (MEOP) (Treasure et al., 2017) illustrate this well, as about $70 \%$ of oceanographic profiles measured south of $60^{\circ} \mathrm{S}$ come from bio-loggers (Fedak, 2013).

Regarding foraging ecology, bio-loggers were developed to measure the temperature inside the stomach (Wilson and Culik, 1991) or the esophagus (Ancel et al., 1997) of seabirds to detect prey ingestion and to some extent, size (but see Grémillet and Plös, 1994). Other approaches used beak movements (Wilson et al., 2002a), speed changes (Wilson et al., 2002b), accelerometry
(Yoda et al., 2001), changes in diving profiles (Bost et al., 2007), a combination of these (Ropert-Coudert et al., 2001), or videocameras mounted on animals (e.g., Krause et al., 2015; Thiebot et al., 2017) to infer prey encounter and/or ingestion.

\section{Biomolecular Methods Foraging}

Information on predators' feeding ecology is required to understand how changes in their prey might affect their status, as well as understand the status of their prey. Methods for learning about feeding ecology have evolved from early dietary studies collecting stomachs from dead animals, through using stomach evacuation procedures on live animals (Wilson, 1984), to modern genetic and other techniques for assessing prey composition from feces or tissue samples (McInnes et al., 2017a).

Stable isotope analysis has become popular for investigating predator diet and foraging habitat (e.g., Newsome et al., 2010). Most often, nitrogen $\left(\delta^{15} \mathrm{~N}\right)$ and carbon $\left(\delta^{13} \mathrm{C}\right)$ stable isotope ratios are used to estimate trophic level and foraging habitat, respectively. The latter relies on the strong baseline $\delta^{13} \mathrm{C}$ latitudinal gradient, or "isoscape" in the Southern Ocean (e.g., Jaeger et al., 2010; Brault et al., 2018). Oxygen stable isotope ratios $\left(\delta^{18} \mathrm{O}\right)$ provide additional dietary information in some cases (e.g., Connan et al., 2019). Multiple tracers can be used together in mixing models to estimate predator diet (e.g., Lübcker et al., 2017 ), provided potential prey values are also measured, or to investigate the isotopic niche of different individuals, populations or species (e.g., Connan et al., 2019). The analysis of "archival" 


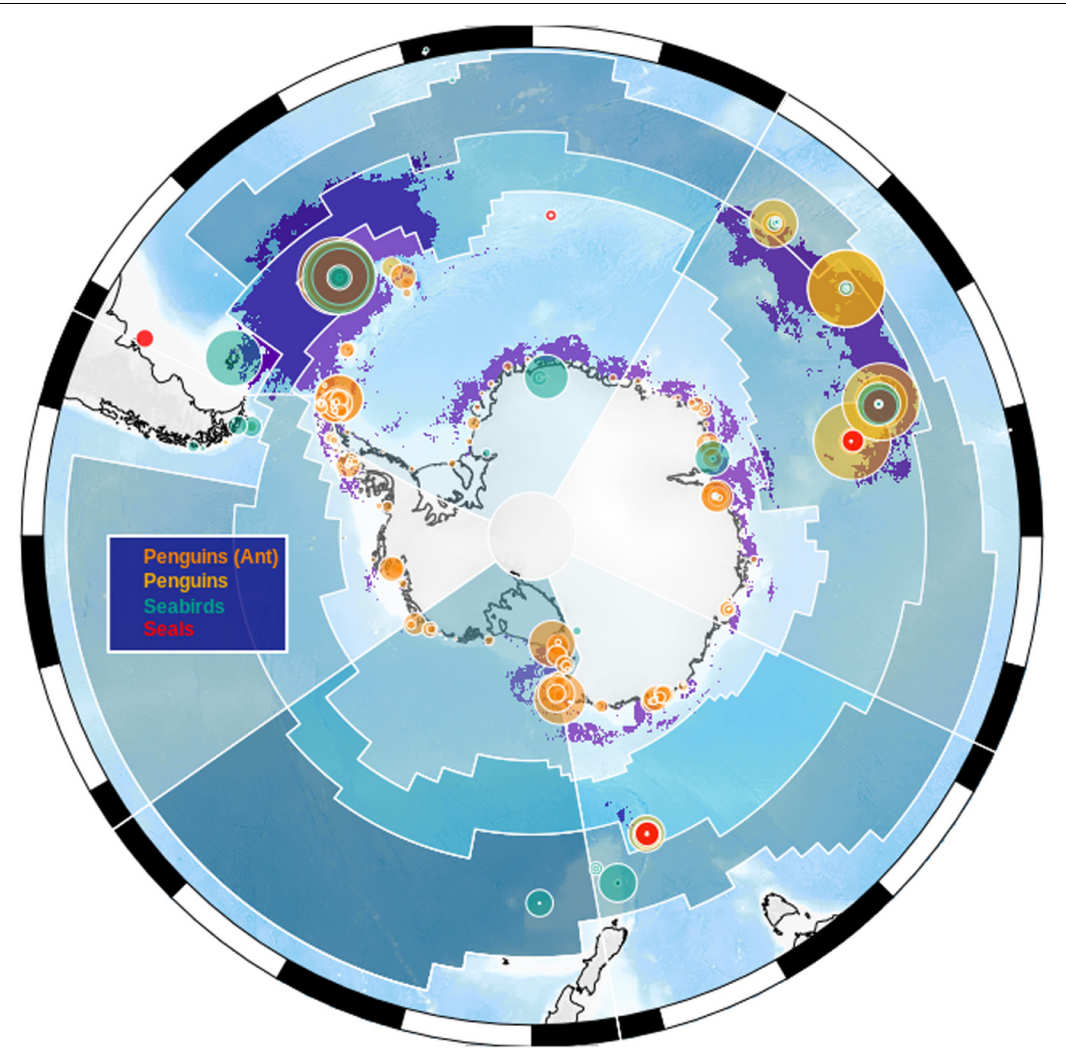

FIGURE 3 | Circumpolar distribution of top predator breeding and foraging sites in relation to the MEASO spatial areas. Purple shading indicates areas of ecological significance for multiple top predators (Hindell et al., 2020). Colored circles are scaled relative to colony size for 14 species (following Hindell et al., 2020; largest count is for macaroni penguins (Eudyptes chrysolophus) at Crozet with > 2 million birds, Crossin et al., 2013). Blue shading demarcates the MEASO spatial areas.

tissues such as whiskers (e.g., Lübcker et al., 2017) or teeth (e.g., Authier et al., 2012) can provide time series of stable isotope ratio values. Commonly, these use bulk analysis but more recently, compound-specific stable isotope analysis has proved to be a powerful tool for enabling more nuanced ecological inference (e.g., Brault et al., 2019).

A less-used biomolecular method for studying marine predator diets is fatty acid analysis of adipose tissues (e.g., Bradshaw et al., 2003) or stomach oils (e.g., Connan et al., 2014). When prey fatty acid signatures are also available, quantitative signature analysis of blubber in marine mammals, or subcutaneous adipose tissue in seabirds allows dietary reconstruction (Iverson et al., 2004).

\section{Genetics}

Molecular genetic markers can estimate the abundance, diversity, connectivity or distribution of populations, species and ecosystems, and track changes in these parameters over time (Schwartz et al., 2007). Genetic analyses have been conducted on a wide variety of Antarctic predators, for example to understand the geographical features that separate populations, monitor population abundance and effective size in colonies, identify species that are not readily recognizable and measure genetic diversity. The commonly used genetic markers have evolved from allozyme analyses to study protein-based differences between individuals (e.g., Smith and McVeagh, 2000), to mitochondrial DNA, useful for understanding maternally inherited patterns (e.g., Christiansen et al., 2018). Rapidly evolving nuclear microsatellite markers enable individuals to be identified, measurement of effective population size (e.g., Hoffman et al., 2011), detecting levels of population differentiation (e.g., Amaral et al., 2016) and monitoring of population changes over management-relevant timescales (e.g., Forcada and Hoffman, 2014). Finally, single nucleotide polymorphism markers (SNPs) can be obtained in their thousands via restriction site-associated (RAD) or whole genome sequencing approaches (e.g., Clucas et al., 2018; Cole et al., 2019).

For cetaceans and seabirds, most genetic studies have focused on population connectivity and diversity across breeding sites or oceanic areas. Levels of diversity and connectivity are important to gauge the level of isolation and vulnerability, particularly of exploited or threatened populations. Baleen whales from geographically distinct wintering grounds often mix within their Southern Ocean feeding grounds, so patterns of spatial genetic structure are usually weak (e.g., Amaral et al., 2016; Attard et al., 2016). Genetic diversity is particularly low for southern right whales (Eubalaena australis); following three centuries of exploitation, populations such as that in the New Zealand Auckland Islands exhibit low mitochondrial DNA diversity (Patenaude et al., 2007), with genetic differentiation between 
calving grounds suggesting demographic independence between populations (Carroll et al., 2015). Multiple markers are required to reliably detect weak structuring. RAD-Seq analyses of four penguin species uncovered weak population structuring across their Southern Ocean range, indicating regular long-distance migratory movements between colonies (Younger et al., 2016; Clucas et al., 2018). In contrast, gentoo penguins (Pygoscelis рариа), with their restricted, coastal distribution, are much more genetically isolated (Levy et al., 2016; Clucas et al., 2018). Hoffman et al. (2011) used SNPs to assess the preexploitation abundance and subsequent population bottleneck of Antarctic fur seals (Arctocephalus gazella) at South Georgia due to sealing, finding robust evidence for a recent population decline consistent with over-exploitation. Genetic monitoring of colonies over time can also be extremely valuable to understand population abundance, survival rates and response to local environmental conditions. Regular genetic monitoring of Weddell seals (Leptonychotes weddellii) on White Island has enabled pedigree reconstruction since 1990, facilitating annual estimation of effective population sizes. Across three reconstructed generations, heterozygosity declined from past to present and is likely to decline further if the current generation of pups continue to interbreed (Gelatt et al., 2010).

\section{Physiological Status}

The physiological status of top predators is now being monitored by measuring various parameters in a range of tissues. In humpback whales steroid hormones are measured in blubber samples to determine pregnancy and obtain demographic rates (Pallin et al., 2018), providing some baseline against which to assess impacts of change. Steroid hormones have recently been measured sequentially in the whiskers of three seal species and this approach can be used to study reproductive cycles in mammals with cryptic life stages, or study links between animal stress and environmental variation (Lübcker et al., 2020). In response to stressors, secretion of glucocorticoid dramatically increases to mediate breeding and foraging decisions (review in Wingfield et al., 1998). The importance of oxidative stress in influencing fitness components and the resolution of life history trade-offs is attracting increasing attention (Monaghan et al., 2009). Adélie penguins (Pygoscelis adeliae) modulate their oxidative status by adopting different foraging behavior (Beaulieu et al., 2010). In humpback whales an adiposity index measured in blubber biopsy samples cycled over 8 years in synchrony with environmental variables (e.g., sea-ice concentration, negative relationship) and climate indices (e.g., ENSO, positive relationship) (Bengtson Nash et al., 2018).

\section{Developing an Integrated Perspective}

The suite of tools developed over the past decades, briefly summarized above, are increasingly used in combination on the same individuals and populations. Advances in micro technologies, lab analyses and field techniques have made this possible practically and ethically. In less than $10 \mathrm{~min}$, an animal can be instrumented, and blood and/or feces sampled with minimally invasive approaches. Data on individual performance/condition can be collected at regular intervals, at least for land-based breeding species, and when paired with demographic parameters at the population level, they turn top predators into "living observatories" (Figure 4), the biological counterpart to the physical sciences observatories.

\section{Biases and Regional Coverage}

Data collected on top predators are commonly biased toward certain groups. Overwhelmingly, the individuals studied are adults but there is a concerted effort to learn more about juveniles (e.g., Orgeret et al., 2016). In seals, studies are biased toward adult females since adult males are relatively large and difficult to restrain physically. Most work has focused on seals and seabirds since they are easier to observe, catch and/or handle when they return to their terrestrial sites - than cetaceans which remain at sea, although technological advances are making it possible to study new aspects of their lives (Nowacek et al., 2016). While commercial whaling provided substantial historical data, this again contains very little information on juveniles due to the target catch of the industry. Three dedicated abundance surveys (Table 1) provided standardized circumpolar data on whale abundance, distribution and trends, however, many cetacean species are rare and remain infrequently observed.

Relative to the MEASO areas, many of the longitudinal datasets come from locations where researchers have access to breeding, resting or molting sites on land and ice, frequently near research infrastructure on Subantarctic islands in the Atlantic, Central Indian and East Indian sectors, at the Antarctic Peninsula, as well as in east Antarctica and the Ross Sea in the Antarctic zone.

\section{Open Data and Computing}

Antarctic scientists are acutely aware of the necessity of making their data publicly available and shareable, following from the requirement of Article III of the Antarctic Treaty. Accordingly, the Scientific Committee on Antarctic Research houses groups that are dedicated to the proper curation and sharing of data and metadata such as the Standing Committee on Antarctic Data Management or the Expert Group on Antarctic Biodiversity Informatics (Van de Putte et al., to be published in this research topic). While there is disparity in practices and data standards among research groups, there are several international efforts promoting free data and/or metadata access of top predator studies (Table 1). Furthermore, a push toward better reproducibility of results accompanied by the growth of open-source computing has meant that many projects and researchers now make their computer code freely available (e.g., the Antarctic/Southern Ocean rOpenSci community; Raymond and Sumner, 2018).

\section{BIOLOGY, DRIVERS AND FUNCTIONAL RELATIONSHIPS}

\section{Marine Predators in a Changing Climate}

A core component of the MEASO work program has been to provide a source of standardized and validated information on 


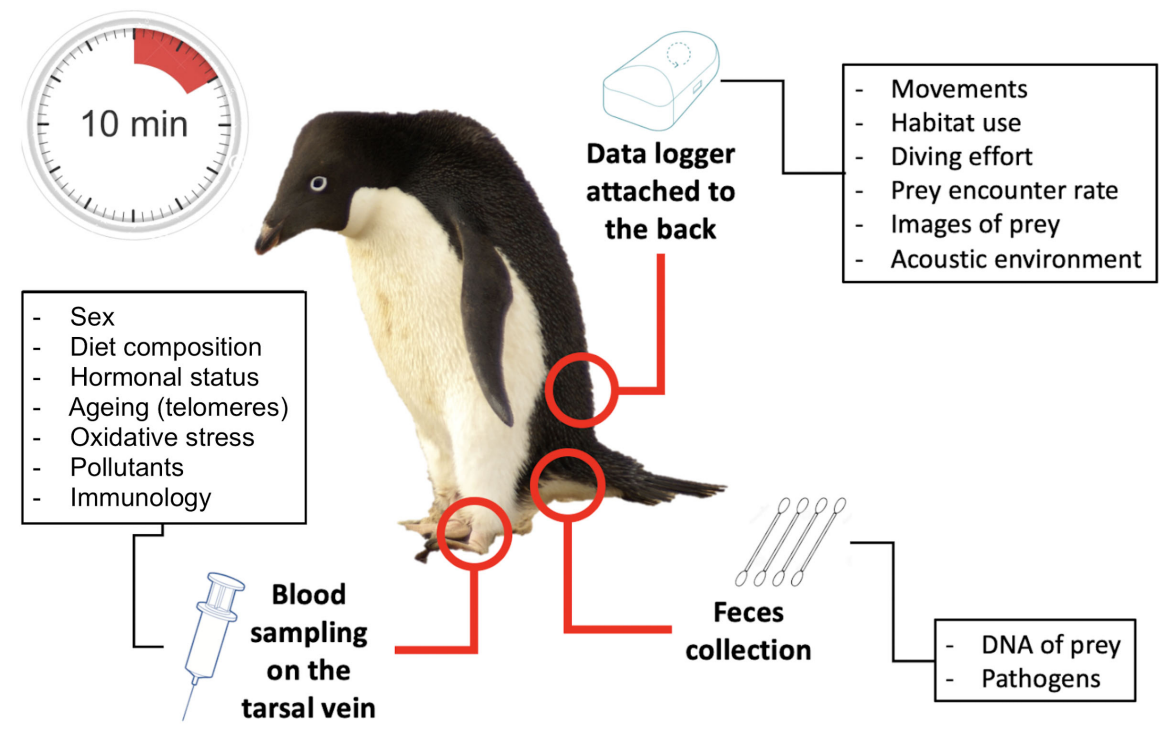

FIGURE 4 | Example of a living observatory, an Adélie penguin, demonstrating the diversity of information that can be obtained from individual-based studies.

TABLE 1 | A non-exhaustive list of existing large-scale initiatives to collate and make openly available data on Southern Ocean marine top predators.

Antarctic and Southern Ocean initiatives

Population trends

Distribution at sea

Abundance and distribution

Oceanographic data from animal-borne devices

Trophic information

Related initiatives

Distribution

Animal distribution and bio-physical data from animal-borne devices

Distribution
Mapping Application for Penguin Populations and Projected Dynamics (MAPPPD)

Biogeographic Atlas of the Southern Ocean (SCAR product)

Retrospective Analysis of Antarctic Tracking Data (RAATD)

International Whaling Commission (IWC) Southern Ocean Whale and Ecosystem Research Programme $($ SOWER)*

Antarctic Pack Ice Seals (APIS) Programme*

Marine Mammals Exploring the Oceans Pole to Pole (MEOP)

The Penguiness Book of dive records

Southern Ocean Dietary Database (an EGABI product)

Movebank for Animal Tracking Data

Integrated Marine Observing System

BirdLife International Seabird Tracking Database http://www.penguinmap.com/

Humphries et al. (2017)

http://atlas.biodiversity.aq/

https://github.com/SCAR/RAATD

https://iwc.int/sower

https://www.seals.scar.org/pdf/ IntAPISSummUpdateRevis.pdf

http://www.meop.net/

http://www.penguiness.net/

https://data.aad.gov.au/trophic/

https://www.movebank.org/cms/ movebank-main

http://imos.org.au/

https://portal.aodn.org.au/

http://www.seabirdtracking.org//
De Broyer et al. (2014)

Hindell et al. (2020); Ropert-Coudert et al. (2020)

E.g., Branch (2011)

Southwell et al. (2012)

Treasure et al. (2017)

Ropert-Coudert et al. (2018a)

Raymond et al. (2011)

Kranstauber et al. (2011)

Harcourt et al. (2019)

E.g., Lascelles et al. (2016)

*Indicates inactive initiatives.

the Southern Ocean Knowledge and Information wiki (SOKI). The SOKI biota pages ${ }^{3}$ summarize basic information for a species or taxonomic group for flying birds, penguins, seals, baleen whales, dolphins and toothed whales, and how the status and ecology of the group may be changing over time. We refer the reader to this resource for detailed species-level information including life history parameters (where available), population estimates and dynamics, movement and distribution, diet and

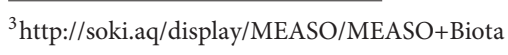

energetics, and species interactions and dependencies. In this section we provide a high-level overview of drivers and functional relationships, from an ice-dependent and oceanic perspective, and highlight the overarching importance of climate change impacts upon Southern Ocean top predators.

\section{Ice-Dependent Predators}

Depending on their affinity for sea ice, marine predators are either directly influenced by sea ice as a platform on which to forage or rest (and other stages of life cycle), or indirectly 
through associated processes such as biological production and prey aggregation (Murphy et al., 2007; Massom and Stammerjohn, 2010; Flores et al., 2012). Antarctic sea ice extent shows interannual variability with marked regional variation (Zwally et al., 2002; Cavalieri and Parkinson, 2012; Hobbs et al., 2016; Parkinson, 2019). Changes in extent and seasonality have important implications for the structure and functioning of Southern Ocean ecosystems (Massom and Stammerjohn, 2010; Morley et al., to be published in this research topic). Predators exhibit differential usage of sea-ice areas with distinct characteristics, from north to south the: (i) marginal ice zone; (ii) pack ice; (iii) coastal zone comprising landfast (fast) ice with recurrent polynyas and flaw leads.

Sea-ice obligate pack-ice seals - crabeater (Lobodon carcinophaga), leopard (Hydrurga leptonyx), Ross (Ommatophoca rossii) and Weddell seals - and the emperor penguin use sea ice as a platform for breeding and molt. Volant seabirds such as snow (Pagodroma nivea) and Antarctic petrels (Thalassoica antarctica) spend long periods sitting on icebergs or large ice floes (Delord et al., 2020). Crabeater, leopard, and Ross seals avoid areas of consolidated pack ice where freeze-ups are frequent and restrictive (Ribic et al., 1991). Crabeater and leopard seals are predominantly southern pack-ice species year-round. In contrast, Ross seals spend $\sim 70 \%$ of their time $500-1000 \mathrm{~km}$ from the ice edge. They haul out in the pack ice mainly during the December-January molt, and in October-November when they breed (Arcalís-Planas et al., 2015).

Although southern elephant seals (Mirounga leonina) mate, breed and molt on subantarctic islands, a significant proportion forage within the Antarctic sea ice region in winter (Hindell et al., 2017). Compared with other marine mammals, whales have limited capacity to make breathing holes through ice (Nicol et al., 2008). Antarctic minke whales (Balaenoptera bonaerensis) are known to overwinter in the Antarctic; although sighted within the winter pack ice the proportion of the population that remains year-round is unknown (Perrin et al., 2018). At least two different ecotypes (B and C) of killer whales (Orcinus orca) are present near or within the Antarctic sea-ice region (Pitman, 2011). "Pack ice killer whales" (B-types) forage mainly among the pack ice around the entire continent. "Ross Sea killer whales" (C-types) live deep in East Antarctic pack ice and use leads (cracks) in the fast ice, often far from open water. Sei whales (Balaenoptera borealis), southern right whales, A-type and D-type killer whales are not, or rarely, seen close to the sea-ice edge.

In the Southern Ocean baleen whale diets are predominantly euphausiid based, reflecting the available biomass of different krill species, but with the super-abundant Antarctic krill being the primary prey for many whales and other species (Box 1) (see also Rogers et al., 2020; Johnston et al., to be published within this research topic; and references therein). The small size of minke whales allows them to enter the pack ice zone and affords access to Antarctic krill there. In addition, their ability to filter large quantities of krill provides an advantage over smaller krill predators that feed on individual prey (Friedlaender et al., 2014). Humpback and fin whales (Balaenoptera physalus) are also krill specialists but are more oceanic-dwelling and less associated with sea-ice habitats or continental shelf areas (see
Nicol et al., 2008). Humpback whales generally arrive in Antarctic waters in December and their numbers increase throughout summer months (e.g., Andrews-Goff et al., 2018; Bestley et al., 2019). Antarctic blue (Balaenoptera musculus intermedia) and fin whales appear to show up comparatively later in the summer (Širović et al., 2009).

Sea-ice predator populations do not respond uniformly to seaice changes around Antarctica (Table 2). Different functional relationships and contrasting population trends reflect regionally specific differences in sea ice change and variability, and in species ecology and life history (Jenouvrier et al., 2005; Massom and Stammerjohn, 2010; Constable et al., 2014; Southwell et al., 2015). Sea ice characteristics affect foraging behavior (e.g., Le Guen et al., 2018) and breeding habitat (Jenouvrier et al., 2017), with consequences on vital rates (reproduction: Jenouvrier et al., 2003; Massom et al., 2009; Stroeve et al., 2016; RopertCoudert et al., 2018a; survival: Barbraud and Weimerskirch, 2001b; Jenouvrier et al., 2005; Kooyman et al., 2007; Fretwell and Trathan, 2019), ultimately affecting population dynamics (Jenouvrier et al., 2003, 2012; Ainley et al., 2010) and species persistence (Jenouvrier et al., 2014).

Predators employ a diversity of foraging strategies within the sea-ice zone (Supplementary Material 1). Knowledge of the present and predicted effects of sea-ice changes on predators around Antarctica is limited for whales compared with other vertebrate predators for which long-term demographic data exist (Table 2). However, extended feeding seasons for humpback and minke whales' habitat use were tightly correlated with presence of sea ice (Friedlaender et al., 2006; Williams et al., 2014).

Predictions about the effect of Antarctic sea ice changes and variability on predators is a complex question, arising from three factors. First, there remain important uncertainties in understanding of sea-ice variability, change, climate model configurations and forecasts. Sea-ice dynamics (timing and duration), sea icescapes (ephemeral and persistent latent heat polynyas, icebergs, and leads) and sea-ice extent are highly variable in time and space. In most ecological studies the scales used are too coarse to accurately or realistically understand the reliance of Antarctic predators upon sea ice (Jenouvrier et al., 2012). New approaches, using drones (Torres et al., 2018), high resolution satellite imagery (LaRue et al., 2019) or animal-borne sonar (Lawson et al., 2015) can investigate fine-scale features relevant to the foraging scale of predators.

Second, diversity in behavior and individual phenotypic plasticity makes predator responses to sea-ice changes highly variable between sites, individuals and across species. The response of predators is governed by their physiological plasticity to tolerate change, adapt to new environmental conditions or migrate to alternative foraging grounds that enable survival.

Third, the complexity of trophic interactions within the sea ice region is poorly understood, limiting the understanding of how sea ice changes would affect predators through changes in the availability of resources. The role of winter sea ice as a main feeding ground for Antarctic krill larvae was recently challenged, as the pack ice zone may be a food-poor habitat for larval development compared with the marginal ice zone (Meyer et al., 2017). Diet indicators suggest that larvae feed on sea-ice 
BOX 1| Food web interactions of Southern Ocean top predators.

Climate-driven changes are influencing the timing, duration and intensity of primary production in the Southern Ocean, with marked regional variability (high confidence) (IPCC, 2019), and through a cascading effect modifications in the lower trophic level planktonic communities transfer up the food web (Constable et al. 2014; Rogers et al., 2020). Many climate-driven changes impacting predators can therefore manifest through changes in the timing and availability of key prey resources (medium confidence), with consequences for aspects of predator's life history, phenologies, migratory schedules, foraging distributions and spatial ranges as detailed in see section "Biology, Drivers and Functional Relationships." One often-cited example of such bottom-up control is through Antarctic krill: this crustacean play a central role in high latitude Southern Ocean food webs, as grazers and prey for baleen whales, seals, penguins and seabirds (Trathan and Hill, 2016), although its abundance and importance does vary between regions (McCormack et al., 2017). The Antarctic krill life cycle is tightly synchronized to take advantage of the seasonal availability of sea-ice habitat and the phenology of Southern Ocean phytoplankton productivity. Bottom-up ecosystem changes have been reviewed extensively, including for primary (Pinkerton et al., to be published in this research topic) and secondary production (zooplankton and krill: Johnston et al.; fish and squid: Caccavo et al., to be published in this research topic). Top-down control can additionally be important in Southern Ocean ecosystems, as an overabundance of predators can lead to local prey depletion thereby releasing the pressure that these prey species exerted on primary producer levels (Ainley et al., 2007). The state of knowledge regarding key regional Southern Ocean food web structures, function and dynamics are reviewed by McCormack et al. (to be published in this research topic), together with prognoses for how the relative importance of trophic pathways will change under climate change.

resources when available but can still persist in the water column when they are not (Walsh et al., 2020).

Extensive research is yet to be done regarding foraging activity by predators below the ice and quantification of key dependencies, particularly during the autumn and winter. Three main questions are: (1) How do oceanographic conditions shape predator distribution at-depth under sea ice? Key associations of interest relate to in situ temperature and salinity gradients, specific water mass properties, topographic structures (creating local upwelling or sub-mesoscale structures) within the different ice zones and latent-heat polynya dynamics. (2) Where and when does primary and secondary production occur within sea ice and latent-heat polynyas during autumn? The sea-ice region is still considered a biological desert in winter although predators forage there successfully throughout the year. Sparse data are due to limited ship access, and non-detection of ice-associated phytoplankton in conventional satellite ocean-color images. (3) How do predators track the zooplankton, ichthyoplankton and macrofauna distribution at the ice-ocean interface down to mesopelagic depths? The suite of complementary data-collection and monitoring tools (see section "Data, Methods, and Tools") can help address these questions.

\section{Oceanic Processes and Marine Predators}

In the Special Report on the Ocean and Cryosphere in a Changing Climate (SROCC; IPCC, 2019), medium confidence was attributed to the identification and location of environmental features that facilitate the aggregation of prey, and in turn influence the spatiotemporal distribution of Antarctic marine mammals and birds (Meredith et al., 2019). However, changes in predators' biology and activity patterns are interpreted with high confidence to be the result of increasing environmental variability and climate change (Meredith et al., 2019).

\section{Circulation (advection) and fronts}

Changes to the ocean circulation and structure are considered by Morley et al. (to be published in this research topic). Circulation can impact biological productivity, prey abundance and distribution, thereby determining foraging hot spots (Hunt et al., 2016; Atkinson et al., 2019). In the subantarctic region of the Antarctic Circumpolar Current (ACC), the advection of biologically enriched waters downstream from major bathymetric features (Cotté et al., 2015), and the transport of zooplankton and micronekton in the lee vicinity of islands, is postulated to supply much of the food necessary for the survival of the land-based predators feeding offshore (Perissinotto and McQuaid, 1992). Subantarctic (Arctocephalus tropicalis) and Antarctic fur seals from the Prince Edward Islands displayed less searching behavior associated with foraging when current speed increased (Wege et al., 2019). The decline of several seal and bird populations at the Prince Edward Islands has been linked to long-term decline in inshore primary productivity driving changes in prey availability, associated with regional scale shifts in ACC circulation (Allan et al., 2013). Recent research has found no long-term trend in the zonally averaged latitude of ACC transport and no evidence of an increase in the ACC transport (Chidichimo et al., 2014).

The ACC fronts are associated with boundaries between the major water masses. These circumpolar features exhibit high biological production due to upwelling or changes in the vertical distribution of resources (Moore and Abbott, 2000). They offer important foraging habitat for top predators (Tynan, 1998; Bost et al., 2009; Arthur et al., 2016). Despite representing relatively predictable foraging grounds, frontal areas are also characterized by a complex pattern of multiple locations corresponding to different jets (Sokolov and Rintoul, 2009). Large-scale climatic anomalies generating interannual variability in the latitudinal location of fronts impacts the foraging trip distances and feeding depths of king penguins (Aptenodytes patagonicus), with consequences for population size (Bost et al., 2015). Potential change in the transport and location of the ACC and its fronts, in response to the increasingly positive Southern Annular Mode, is expected to affect subantarctic foraging top predators (Allan et al., 2013). However, satellite altimetry and temperature time-series show consensus on the lack of poleward frontal displacement over recent decades (Gille and Meredith, 2017; Chapman et al., 2020). Consequently, frontal proxies such as sea surface temperature (SST) are unreliable for projection studies because a decoupling with the location of the fronts (spatial gradients or isopycnal slopes) may occur due to strong surface warming (Cristofari et al., 2018; Meijers et al., 2019). However, temperature is an important parameter for the investigation of predators foraging habitat within frontal areas since it controls prey distribution and availability (Reisinger et al., 2018). 
TABLE 2 | Reviews the existing state of knowledge on effects of sea-ice drivers upon Southern Ocean top predators.

\begin{tabular}{|c|c|c|c|c|c|}
\hline Driver & Effect & Species name & Brief summary of impact & Geographic zone & References \\
\hline \multirow[t]{13}{*}{ Decreased sea-ice extent } & Negative & $\begin{array}{l}\text { Antarctic fur } \\
\text { seal/gentoo and } \\
\text { macaroni } \\
\text { penguins/black browed } \\
\text { albatrosses } \\
\text { (Thalassarche } \\
\text { melanophris) }\end{array}$ & Population number/frequency of years of low reproductive output & South Georgia & Reid and Croxall, 2001 \\
\hline & Negative & Emperor penguins & Decline by $50 \%$ of emperor penguin population & $\begin{array}{l}\text { Terre Adélie, East } \\
\text { Antarctica }\end{array}$ & $\begin{array}{l}\text { Barbraud and } \\
\text { Weimerskirch, 2001b }\end{array}$ \\
\hline & Negative & Adélie penguins & Krill availability, foraging activity & $\begin{array}{l}\text { Western Antarctic } \\
\text { Peninsula }\end{array}$ & $\begin{array}{l}\text { Fraser and Hofmann, } \\
2003\end{array}$ \\
\hline & Negative & 9 seabird species & Later arrival and laying than in early 1950 s & East Antarctica & $\begin{array}{l}\text { Barbraud and } \\
\text { Weimerskirch, } 2006\end{array}$ \\
\hline & Negative & $\begin{array}{l}\text { Snow petrels/emperor } \\
\text { penguins }\end{array}$ & $\begin{array}{l}\text { The emperor penguin population has declined by } 50 \% \text { whereas } \\
\text { snow petrels showed their lowest numbers in 1976, but were able } \\
\text { to skip reproduction }\end{array}$ & $\begin{array}{l}\text { Terre Adélie, East } \\
\text { Antarctica }\end{array}$ & Jenouvrier et al., 2005 \\
\hline & Negative & 3 whale species & $\begin{array}{l}\text { Increased spatial overlap due to shift of fin whales foraging range to } \\
\text { higher latitudes where blue and minke whales used to feed }\end{array}$ & Circumpolar & Nicol et al., 2008* \\
\hline & Negative & $\begin{array}{l}\text { Crabeater/Weddell/elephant } \\
\text { seals }\end{array}$ & Limitation in the available breeding and foraging habitat & $\begin{array}{l}\text { Western Antarctic } \\
\text { Peninsula }\end{array}$ & Costa et al., 2010* \\
\hline & Negative & $\begin{array}{l}\text { Adélie/Chinstrap } \\
\text { (Pygoscelis antarcticus) } \\
\text { penguins }\end{array}$ & Decreased in both populations, change in their main prey & $\begin{array}{l}\text { Western Antarctic } \\
\text { Peninsula }\end{array}$ & Trivelpiece et al., 2011 \\
\hline & Negative & $\begin{array}{l}\text { Crabeater/Weddell/leopard } \\
\text { seals }\end{array}$ & $\begin{array}{l}\text { Reduced food resources for pack-ice seals, predicted loss of seal } \\
\text { habitat (1979/2011) }\end{array}$ & $\begin{array}{l}\text { Western Antarctic } \\
\text { Peninsula/Western } \\
\text { Weddell Sea }\end{array}$ & Forcada et al., 2012 \\
\hline & Negative & Adélie penguins & $\begin{array}{l}\text { Prediction of population going extinct; potential mitigation by local } \\
\text { recruitment }\end{array}$ & $\begin{array}{l}\text { Edmonson Point, Ross } \\
\text { Sea }\end{array}$ & Ballerini et al., 2015 \\
\hline & Negative & Adélie penguins & $\begin{array}{l}\text { Negative influence on population growth rate for conditions } 4 \text { years } \\
\text { prior (1982-2015; may be site dependent) }\end{array}$ & Circumpolar & $\begin{array}{l}\text { Che-Castaldo et al., } \\
2017\end{array}$ \\
\hline & Negative & Antarctic minke whales & $\begin{array}{l}\text { Decreased preferred foraging habitat and shelter from predation } \\
\text { leading to displacement and competition with other krill predators } \\
\text { (e.g., humpback whales) }\end{array}$ & Circumpolar & Risch et al., 2019* \\
\hline & Negative & Arctic terns & Impact on foraging behavior & East Antarctica & $\begin{array}{l}\text { Redfern and Bevan, } \\
2020\end{array}$ \\
\hline \multirow[t]{2}{*}{$\begin{array}{l}\text { Decreased sea-ice extent } \\
\text { and duration }\end{array}$} & Negative & $\begin{array}{l}\text { Adélie/chinstrap } \\
\text { penguins }\end{array}$ & $\begin{array}{l}\text { Replacement of Adélie by chinstrap penguins due to change in } \\
\text { resources }\end{array}$ & $\begin{array}{l}\text { West Antarctic } \\
\text { Peninsula }\end{array}$ & Ducklow et al., 2007 \\
\hline & Negative & Crabeater seals & $\begin{array}{l}\text { Prediction of direct (pupping platform and protection from } \\
\text { predators) and indirect (food supply) influences }\end{array}$ & Circumpolar & Siniff et al., 2008* \\
\hline
\end{tabular}


TABLE 2 | Continued

\begin{tabular}{|c|c|c|c|c|c|}
\hline Driver & Effect & Species name & Brief summary of impact & Geographic zone & References \\
\hline $\begin{array}{l}\text { Decreased sea-ice } \\
\text { concentration }\end{array}$ & Negative & $\begin{array}{l}\text { South polar skuas } \\
\text { (Stercorarius } \\
\text { maccormicki) }\end{array}$ & Population size and number of breeders & $\begin{array}{l}\text { Terre Adélie, East } \\
\text { Antarctica }\end{array}$ & Pacoureau et al., 2019 \\
\hline $\begin{array}{l}\text { Increased/decreased } \\
\text { sea-ice concentration }\end{array}$ & Negative & Emperor penguins & Predicted colony declines (bell shape curve) & Circumpolar & $\begin{array}{l}\text { Jenouvrier et al., 2012, } \\
2014,2019\end{array}$ \\
\hline \multirow[t]{6}{*}{ Increased sea-ice extent } & Negative & Emperor penguins & Fecundity (1952-2000) & $\begin{array}{l}\text { Terre Adélie, East } \\
\text { Antarctica }\end{array}$ & $\begin{array}{l}\text { Barbraud and } \\
\text { Weimerskirch, 2001b }\end{array}$ \\
\hline & Positive & Emperor penguins & Adult survival (1952-2000) & $\begin{array}{l}\text { Terre Adélie, East } \\
\text { Antarctica }\end{array}$ & $\begin{array}{l}\text { Barbraud and } \\
\text { Weimerskirch, 2001b }\end{array}$ \\
\hline & Positive & Snow petrels & $\begin{array}{l}\text { Overall breeding success and fledging body condition the following } \\
\text { year (1973-1999) }\end{array}$ & $\begin{array}{l}\text { Terre Adélie, East } \\
\text { Antarctica }\end{array}$ & $\begin{array}{l}\text { Barbraud and } \\
\text { Weimerskirch, 2001a }\end{array}$ \\
\hline & Negative & Weddell seal & Weaning masses decreased & Erebus Bay, Ross Sea & Proffitt et al., 2007 \\
\hline & Positive & Emperor penguins & $\begin{array}{l}\text { Chick abundances correlated with sea ice extent during } \\
\text { July-September }\end{array}$ & Western Ross sea & $\begin{array}{l}\text { Barber-Meyer et al., } \\
2008\end{array}$ \\
\hline & Negative & Adélie penguins & Foraging trip duration, distance walked, starving time of chicks & $\begin{array}{l}\text { Terre Adélie, East } \\
\text { Antarctica }\end{array}$ & $\begin{array}{l}\text { Ropert-Coudert et al., } \\
2018 b\end{array}$ \\
\hline Increased sea-ice duration & Negative & Elephant seals & $\begin{array}{l}\text { Negative influence on female abundance in breeding colonies with a } \\
\text { 3y lag, likely due to preventing access to profitable prey areas }\end{array}$ & Western Ross sea & $\begin{array}{l}\text { van den Hoff et al., } \\
2014\end{array}$ \\
\hline $\begin{array}{l}\text { Increased sea-ice extent } \\
\text { and duration }\end{array}$ & Positive & Adélie penguins & Food resources & $\begin{array}{l}\text { Palmer, Western } \\
\text { Antarctic Peninsula }\end{array}$ & Saba et al., 2014 \\
\hline \multirow[t]{4}{*}{ Reduced/thinner fast ice } & Negative & Emperor penguins & Population numbers & $\begin{array}{l}\text { Western Pacific/Ross } \\
\text { Sea }\end{array}$ & Ainley et al., 2005 \\
\hline & Negative & Weddell seals & Prediction of changes for pupping and breeding platforms & $\begin{array}{l}\text { McMurdo Sound, Ross } \\
\text { Sea/Antarctic Peninsula }\end{array}$ & Siniff et al., $2008^{*}$ \\
\hline & Positive & Emperor penguins & $\begin{array}{l}\text { Lower-than-average fast ice extent and persistently short distances } \\
\text { to nearest open water (foraging grounds) }\end{array}$ & $\begin{array}{l}\text { Terre Adélie, East } \\
\text { Antarctica }\end{array}$ & Massom et al., 2009 \\
\hline & Negative & Emperor penguins & Prediction of decrease of $\sim 50 \%$ of the colonies for $2025-2052$ & Circumpolar & Ainley et al., 2010 \\
\hline \multirow[t]{2}{*}{$\begin{array}{l}\text { Altered ice floe size and } \\
\text { structure }\end{array}$} & Negative & Crabeater seals & $\begin{array}{l}\text { Prediction of direct (pupping platform and protection from } \\
\text { predators) and indirect (food supply) influences }\end{array}$ & Circumpolar & Siniff et al., $2008^{*}$ \\
\hline & Negative & Ross seals & Prediction of changes for pupping and molting platforms & Circumpolar & Siniff et al., $2008^{*}$ \\
\hline Changed polynya activity & Positive & Adélie penguins & Larger Ross sea polynya/access to food sources & $\begin{array}{l}\text { Western Pacific/Ross } \\
\text { Sea }\end{array}$ & Ainley et al., 2005 \\
\hline \multirow[t]{2}{*}{$\begin{array}{l}\text { Increased } \\
\text { precipitation/snowfall }\end{array}$} & Negative & Adélie penguins & $\begin{array}{l}\text { The change in the icescape following the calving of the Mertz } \\
\text { glacier in 2010, with increase in precipitation and changes in } \\
\text { sea-ice firmness led to } 2 \text { years of massive breeding failure }\end{array}$ & $\begin{array}{l}\text { Terre Adélie, East } \\
\text { Antarctica }\end{array}$ & $\begin{array}{l}\text { Ropert-Coudert et al., } \\
2018 b\end{array}$ \\
\hline & Negative & Adélie penguins & Prediction of decrease of $\sim 75 \%$ of the colonies for $2025-2052$ & Circumpolar & Ainley et al., 2010 \\
\hline Early fast-ice breakup & Negative & Emperor penguins & Substantial loss of chicks & Cape Crozier, Ross Sea & $\begin{array}{l}\text { Schmidt and Ballard, } \\
2020\end{array}$ \\
\hline Increased iceberg mobility & Negative & Emperor penguins & Low chick numbers & Western Ross sea & $\begin{array}{l}\text { Barber-Meyer et al., } \\
2008\end{array}$ \\
\hline
\end{tabular}




\section{Mesoscale eddies and mixed layer dynamics}

The ACC is a turbulent flow with high levels of meandering and eddy energy. These mesoscale features bring nutrient-rich deep water to the surface, consequently locally fueling primary production and sustaining trophic webs (Kahru et al., 2007). The importance of mesoscale eddies has been reported for flying (Nel et al., 2001) and diving birds (Cotté et al., 2007; Scheffer et al., 2016), and seals (Campagna et al., 2006; Bailleul et al., 2010; Massie et al., 2016). Tracking studies have highlighted behavioral adjustments of birds and mammals focusing on distinct mesoscale eddies characterized by their type, level of retention (weeks to months, d'Ovidio et al., 2013), and the history and trajectory of the water parcel (Cotté et al., 2015). Eddies can assist with foraging because of enhanced production, prey aggregation and increased prey accessibility (Della Penna et al., 2015), but not all species, sexes and age-classes interact with eddies in a consistent pattern (see e.g., Dragon et al., 2010; Tosh et al., 2015). Recently, submesoscale features (filaments and small-scale fronts) induced by the interaction between eddies, and characterized by elevated physical and biological activity, were also reported to be favored by southern elephant seals (Cotté et al., 2015; Della Penna et al., 2015; Rivière et al., 2019; Siegelman et al., 2019). Similarly, chinstrap penguins, macaroni penguins, and Antarctic fur seals from Bouvetøya targeted negative sealevel anomalies and sub-mesoscale fronts (Lowther et al., 2014). An increase in eddy energy (McHogg et al., 2015) as a response to the strengthening of westerly winds will affect the mixed layer depth and stratification in the ACC (Hausmann et al., 2017). This will impact the vertical flux of nutrients and limiting elements into the surface layer. Such projected physical change should influence the spatial distribution of production, the role of eddies in structuring the prey field by bottom-up or aggregation processes and the resulting trophic transfer of energy to top predators.

The mixed layer temperature gradient also acts as a barrier for some vertically migrating prey and therefore plays an important role in foraging behavior of deep-diving marine predators (Biuw et al., 2010). Conductivity-temperature-depth data have shown southern elephant seals were less successful foragers when diving in warmer water (McIntyre et al., 2011). Shallow divingpredators, targeting the bottom of the shallow mixed layer depth (e.g., in certain regions or time of the year/day) will be affected by mixed layer depth variations given their physiological inability to dive deep. For example, southern right whales feeding on surface swarming krill, favored areas with a temperature difference of $10-15^{\circ} \mathrm{C}$ in the upper $200 \mathrm{~m}$ of the water column, but also preferred shallower mixed layer depths when foraging (Torres et al., 2013). Increasing temperatures and changes to the mixed layer depth mean that marine predators will have to dive deeper more frequently, i.e., at a greater cost, to obtain the same amount of resources.

\section{Climate Change and Marine Predator Responses}

Temperature increase in some areas of the Southern Ocean has been particularly rapid leading to major oceanographic changes which, in turn, are impacting marine predators (Forcada and Trathan, 2009; Barbraud et al., 2012; Convey and Peck, 2019). Climate change can directly or indirectly impact predator demographics, phenology, distribution, diet and behavior (Sydeman et al., 2015). Separating demographic changes related to climate from other causative mechanisms (e.g., fisheries) is challenging - these are often not independent as impacts may be cumulative - but important to evaluate to develop effective mitigation strategies (Rolland et al., 2010; Trathan et al., 2015). This is especially the case in the Southern Ocean where the recovery of previously exploited species represents a changing influence on community structure and prey dynamics (Ainley et al., 2007).

A number of studies have linked population changes to climate effects. For example, changes in winter SST negatively affected the survival of juvenile black-browed albatrosses and consequently population growth (Jenouvrier et al., 2018). King penguins from Crozet are particularly vulnerable to climate change, partly due to shifting distribution of their major foraging grounds (Péron et al., 2012; Bost et al., 2015; Cristofari et al., 2018). The low adult survival of southern rockhopper penguins (Eudyptes chrysocome) is linked to warmer SST, presumably due to the negative influence on prey (Dehnhard et al., 2013). At Macquarie Island, the long-term population decline $(-1.45 \%$ p.a. over seven decades) of southern elephant seals has been linked to complex changes in ice dynamics along the Victoria Land coast and in the Ross Sea, as increasing ice concentration and extent restricts access of the seals to these foraging areas, forcing them to leave earlier (Hindell et al., 2017). Global climate indices influence southern right whale breeding success by determining variation in food (krill) availability (Seyboth et al., 2016). Coupled climate-biological modeling projected long-term population declines of varying magnitude across five baleen whale species, related primarily to increased competition for reduced prey (copepods/krill) under ocean warming (Tulloch et al., 2019).

The increasing frequency and magnitude of extreme weather events as a result of climate change (high confidence) (IPCC, 2019) also place top predators at risk. Marine predators are philopatric to foraging and/or breeding sites; individuals develop strategies for behavioral specialization and memory effects which can have profound effects on fitness and population persistence (Bradshaw et al., 2004; Grémillet and Boulinier, 2009; Wege et al., 2016b). Philopatric species relying on long-term strategies may be more vulnerable to disruption by increased frequency and intensity of anomalous weather events. Snowstorms, for example, negatively influence breeding success in Antarctic petrels (low confidence) (Descamps et al., 2015). Exceptionally heavy precipitation in East Antarctica disrupted the breeding activity of Adélie penguins on land, while weak katabatic winds preserved the sea ice around the colony, thereby affecting chick provisioning by adults, causing mass mortality of chicks (Ropert-Coudert et al., 2015).

A recent global meta-analysis found only limited shifts in seabirds' reproductive timing over 1952-2015 (Keogan et al., 2018), but changes in breeding or migratory phenology have been reported for several Southern Ocean species. These often represent later rather than earlier onset of breeding, particularly for sea-ice associated species (Barbraud and Weimerskirch, 
2006; Chambers et al., 2014). Nonetheless, Lynch et al. (2012) demonstrated an advancement in clutch initiation with increasing temperatures in three pygoscelis penguin species (Adélie, gentoo and chinstrap). Among humpback whales migrating from Central and South America the arrival time at the Antarctic peninsula has advanced by nearly 30 days in 30 years (Avila et al., 2020). Meanwhile, tracking reveals whales are remaining in ice-free Antarctic Peninsula waters well into winter (Weinstein et al., 2017), leading to longer regional residence times. More detailed investigation may reveal that climate change is differentially affecting population components.

Environmental changes can induce distributional shifts in both the breeding (Forcada and Trathan, 2009) and at-sea foraging distribution of marine predators. Antarctic (Pachyptila desolata; Grecian et al., 2016) and thin-billed (Pachyptila belcheri; Quillfeldt et al., 2010) prions shifted their nonbreeding distribution southward over the past century. The strengthening of westerly winds has resulted in a poleward shift in the foraging distribution of wandering albatrosses but also increased their foraging efficiency and ultimately breeding success (Weimerskirch et al., 2012). Shifts in the latitudinal range of flying seabird species were related to wind and temperature changes during the last decades, depending on the water masses they visited in the Southern Indian Ocean (Péron et al., 2010). Arthur et al. (2018) used species distribution models and satellite-derived ocean data to recreate historical winter (non-breeding) foraging habitats of female Antarctic fur seals from three populations. At Marion and Bird islands, foraging habitat has remained relatively consistent over 20 years, but not at Cape Shirreff; here, reduced sea-ice cover has improved habitat accessibility but also increased the overlap with fisheries. Few studies have used future climate projections to see how predators such as king penguins may shift their movements poleward in response to climate change (medium confidence) (Péron et al., 2012; Cristofari et al., 2018) and how this will impact population abundance. Habitat and climate models applied to tracking data from seven seabird species projected range contractions and poleward shifts (strong likelihood) (Krüger et al., 2018). In the subantarctic region, there is an urgent need for studies that use climate models to create projections of what will happen in the future.

Long-term dietary studies at many Southern Ocean locations have improved understanding of lower trophic level community structure (Ratcliffe and Trathan, 2011), including the trophic roles of krill, myctophids (e.g., Saunders et al., 2019) and other prey resources for specialist (krill or mesopelagic) and more generalist predators (the Southern Ocean Diet and Energetics Database is a key resource, Table 1). Nonetheless, few Southern Ocean studies have associated dietary shifts to climate change (but see Carpenter-Kling et al., 2019, who demonstrated that diet composition of gentoo penguins at Marion Island responds to climate-mediated changes in the position of the subantarctic Front). In the Ross Sea isotopic analyses show that the long-term trophic niche of Weddell seals has not shifted, but the baseline of their food web has, i.e., the primary producer community has changed in this region (Hückstädt et al., 2017).

\section{Interactions With Commercial Fisheries and Resource Extraction Commercial Exploitation Throughout the Southern
Ocean - Past and Present}

In the early 20th century, whalers decimated whale populations sequentially from largest to smallest in the Southern Ocean (Hofman, 2017). In total, $>2$ million whales were taken from the Southern Ocean (Rocha et al., 2014). The International Convention for the Regulation of Whaling (carried out by the International Whaling Commission, or the IWC) came into force in 1946 as an effort to encourage the sustainable harvest for the world's whales. As whale populations continued to decline, the IWC agreed on a whaling moratorium, which came into force in 1985. In 1994, the IWC designated the entire Southern Ocean as a whale sanctuary (Friedheim, 2001). Southern right whales (which were heavily exploited at lower latitudes since the 1600s, de Morais et al., 2016) are now recovering at $\sim 7 \%$ per annum at key sites around the Southern Hemisphere, but are not recovering at others (including Chile-Peru and southeast Australia) (IWC, 2013b; Tulloch et al., 2018). Humpback whale populations are increasing rapidly at $\sim 11 \%$ per annum in many areas (Branch, 2011), and in some cases are close to recovery, such as southwest Atlantic (Zerbini et al., 2019) and east Australia (Noad et al., 2019), while other populations are recovering more slowly (e.g., Oceania; Constantine et al., 2012). In contrast, the Antarctic blue whale was estimated to be at $<1 \%$ of pre-whaling abundance in 1997 (Branch et al., 2004) and is still critically endangered (Thomas et al., 2016). The status of fin and sei whales are less certain due to lack of abundance estimates (Thomas et al., 2016), although see Tulloch et al. (2018) for a model-based assessment of fin whale recovery. Despite the moratorium and sanctuary status, Antarctic minke whales remained subject to low-level whaling as Japan continued to harvest under a national scientific permit until 2019. At the Southern Ocean level, the population is thought to be declining but with low confidence in this trend because of uncertainty in recent abundance estimates and varying trends at a regional level (IWC, 2013a; there is debate whether different abundance estimates are due to minke whale sea-ice usage biasing their availability for survey over time). Currently there is no whaling in the Southern Ocean.

The commercial exploitation of seals began in the late 18th century (Scully, 1978). The sealing trade peaked in the 1820s, with Macquarie Island a key harvesting location for southern elephant seals, Antarctic and subantarctic fur seals. Crabeater and Weddell seals were also hunted but in limited numbers primarily to supply food for sled dogs (Basberg and Headland, 2008). The dramatic surge in fur sealing during the early 19th century saturated the market for seal oil and pelts leading to a gradual decline in prices and imports, and to its cessation in the early 1830s (Basberg and Headland, 2008). With the advent of new sources of lighting, this market slowly faded by the turn of the century (Ling, 1999). While difficult to quantify, given the poor record-keeping, 1.61.7 million fur seals and $>1$ million southern elephant seals 
are believed to have been killed during this era (Basberg and Headland, 2008 and references therein). In 1978, the Convention for the Conservation of Antarctic Seals (CCAS) came into force, setting quotas for all Southern Ocean seal species, with only the Soviet Union conducting exploratory commercial sealing of crabeater seals $(N=4,014)$, leopard seals $(N=649)$, Weddell seals $(N=107)$, Ross seals $(N=30)$ and southern elephant seals $(N=2)$ near the Balleny Islands (Twiss et al., 1985). In contrast, penguins were targeted by commercial sealers and whalers, primarily as a source of food and fuel for fires for those working ashore, though commercial hunting of king penguins for oil was conducted (Trathan and Reid, 2009). Currently there are no sealing operations in the Southern Ocean and while most historically harvested populations have recovered, the status of most seals remains poorly known, especially for pack ice seals (Forcada et al., 2012; Southwell et al., 2012).

\section{Southern Ocean Fisheries Interactions}

Most of the Southern Ocean comprises internationally managed waters apart from maritime Exclusive Economic Zones around several subantarctic islands. The interplay between internationally managed waters, the Antarctic Treaty System (the suite of agreements that govern the Antarctic) and national jurisdiction creates a complex challenge for fisheries management and sustainable use.

The Commission for the Conservation of Antarctic Marine Living Resources (CCAMLR) is the multinational body which governs marine living resources in the Southern Ocean, including responsibility for managing impacts of resource harvesting on dependent and related species. CCAMLR is not a regional fisheries management organization as its primary objective is conservation; however, in the CAMLR Convention "conservation" includes rational use. CCAMLR manages Southern Ocean fisheries (see also Waller et al., to be published in this research topic) including Antarctic krill, toothfish (Dissostichus spp.) and mackerel icefish (Champsocephalus gunnari, Supplementary Material 2). CCAMLR manages for direct operational interactions between fisheries and top predators, implementing a range of strict seabird mitigation measures and other entanglement measures (see section "Operational Interactions - Bycatch"). In line with a precautionary and ecosystem-based management approach $^{4}$ (Kock et al., 2007) CCAMLR also manages for indirect interactions (see section "Food web effects of fishing"), through spatially allocated quotas designed to consider competition with predators, for example through precautionary total allowable catches for Antarctic krill. We return to top predator governance mechanisms more broadly in section "Integrated Conservation Under Uncertainty and Change.”

\section{Operational interactions}

Bycatch. There was a major expansion in the 1970s of demersal fishing in the Southern Ocean, and of pelagic longlining (for

${ }^{4}$ CCAMLR has a clear set of ecological objectives, describing the ecosystem approach as management that: "takes into account all the delicate and complex relationships between organisms (of all sizes) and physical processes (such as currents and sea temperature) that constitute the Antarctic marine ecosystem" (CCAMLR, 2001). tuna and other billfish), demersal longlining and trawling in subtropical and continental shelf waters (Tuck et al., 2003). The associated incidental mortality (bycatch) of seabirds had catastrophic impacts, particularly on albatrosses and large petrels (Phillips et al., 2016; Pardo et al., 2017). Data are sparse on the magnitude of bird bycatch pre-mitigation, but an estimated 6,000 seabirds were killed per year in 1997 in the Patagonian toothfish (Dissostichus eleginoides) fishery around South Georgia (Croxall and Nicol, 2004; Figure 5A), and around 13-14,000 seabirds were killed per year in 2001/03 around Crozet and Kerguelen (Delord et al., 2005; Figure 5B). A suite of mitigation measures were gradually introduced into CCAMLR toothfish fisheries in the late 1990s and early 2000s, including a heavier line-weighting (sinking hooks more rapidly below maximum diving depths), streamer (bird-scaring or Tori) lines behind vessels (discouraging birds from attacking baited hooks), bans on both offal discharge (reducing attraction to vessels) and setting during daylight (when albatrosses are most active). At South Georgia and around Heard Island, a seasonal closure during summer (when most seabirds breed) was implemented as an additional mitigation measure. Together, these measures reduced seabird bycatch to negligible levels (Croxall and Nicol, 2004; Figure 5A). The impact on seabirds of the pelagic trawl fishery for icefish around several subantarctic islands during the period of high fishing effort in the late 1970s and early 1980s is undocumented. However, 50-100 albatrosses and petrels were killed each year in the early 2000s, by which time effort in this fishery was much reduced (Kock, 2007).

While seabird bycatch rates are now very low in fisheries within CCAMLR's jurisdiction, many populations of albatrosses and petrels breeding in the subantarctic still face serious threats from fisheries in subtropical waters. Wandering albatrosses and white-chinned petrels (Procellaria aequinoctialis) are at high risk since their foraging distributions overlap with fisheries without effective bycatch mitigation during both the breeding and non-breeding seasons (Delord et al., 2010; Jiménez et al., 2016). Other species are killed largely during the non-breeding season, when they overlap with tuna fisheries in the High Seas, or demersal longline or trawl fisheries on highly productive continental shelves (Delord et al., 2014; Clay et al., 2019). Although combined mitigation measures can reduce seabird bycatch to negligible levels, regulations beyond CCAMLR waters and some EEZs are not best-practice and monitoring of compliance and bycatch rates is often woeful (Phillips, 2013). Until this is remedied, many populations will remain threatened, despite the efforts of parties to international treaties such as the Agreement on the Conservation of Albatrosses and Petrels (ACAP), and advocacy and education campaigns by dedicated NGOs such as BirdLife International (Phillips et al., 2016).

Antarctic fur seal bycatch occurs in the commercial krill fishery of the South Atlantic sector of the Southern Ocean (CCAMLR Area 48). Although the fishery developed in the 1970s, seal bycatch went unreported to CCAMLR until 2003. In that year, 73 seals were reported by-caught in trawls of one vessel; 26 mortalities and 47 released alive (CCAMLR, 2018c; Figure 6). In 2004, the reported number increased to 292 when monitoring was extended to additional vessels. 


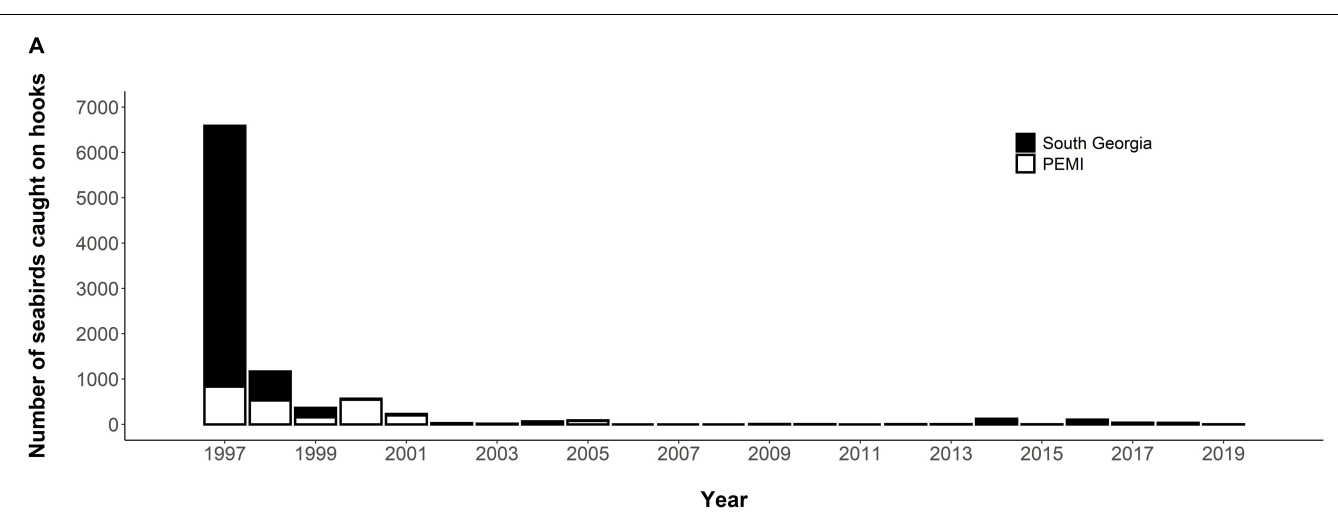

B

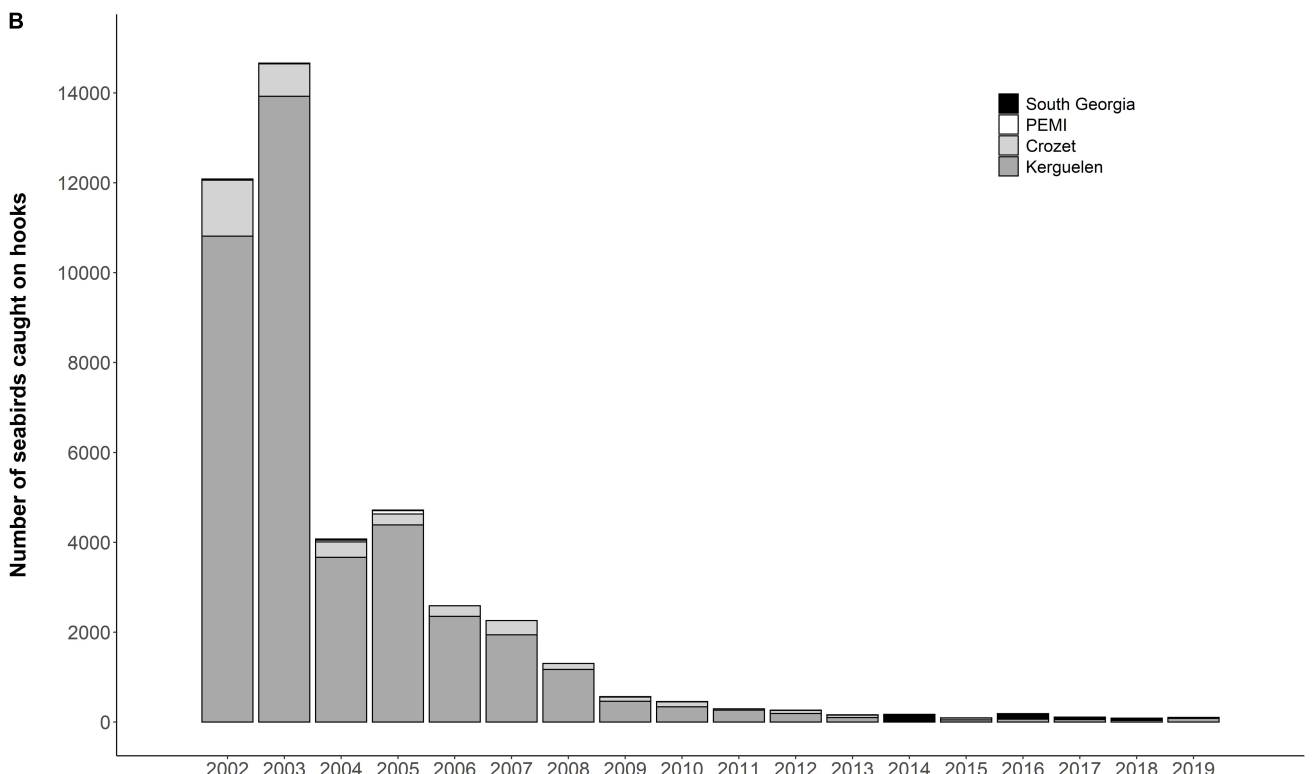

200220032004200520062007200820092010201120122013201420152016201720182019

Year

FIGURE 5 | Bycatch of seabirds in the Patagonian toothfish fisheries of (A) South Georgia and Prince Edward/Marion Islands ("PEMI") from 1997 to 2019; and (B) South Georgia, PEMI, Crozet and Kerguelen from 2002 to 2019 (Source: CCAMLR, 2010, 2019b). Seabird bycatch around Heard Island is excluded as it has amounted to <20 individuals per year since the start of toothfish longlining in 2003 in this region (CCAMLR, 2018c).

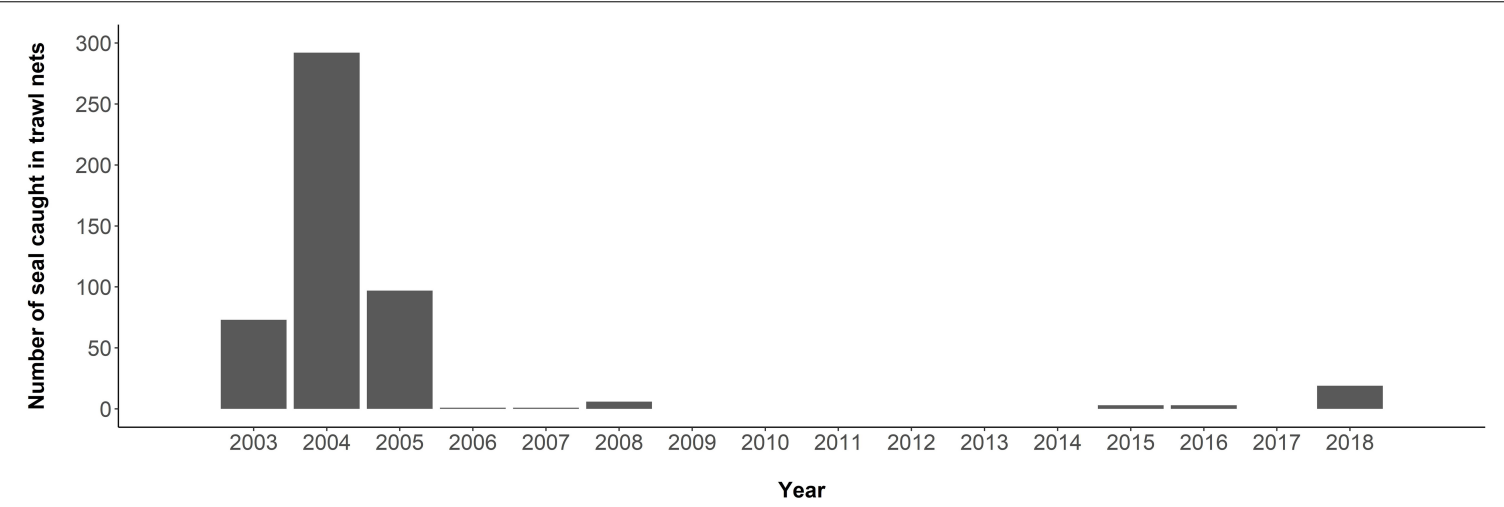

FIGURE 6 | Bycatch of Antarctic fur seals in the krill trawl fishery from 2003 to 2018 in the South Atlantic sector of the Southern Ocean (CCAMLR Area 48). Numbers were not reported between 1973 and 2002 (Source: CCAMLR, 2018a). 
This, and inconsistencies in the data collection and quality, prompted CCAMLR to recommend improved observer coverage and the mandatory use of Marine Mammal Exclusion Devices (MMEDs) by all vessels (Hooper et al., 2005). Trawling systems all require nets fitted with marine predator entanglement mitigation measures to be towed at slow speeds ( $\sim 4$ knots). Fur seal bycatch dropped to $<10$ per year between 2006 and 2017 (CCAMLR, 2018c), but uncertainty around the real extent of these events remains high, as observer coverage is $<100 \%$. In 2018, 19 fur seals were incidentally captured by one krill trawler, which was attributed to a malfunction in the MMED (CCAMLR, 2019b).

Marine mammals are rarely bycaught in toothfish longline fisheries. Antarctic fur seals, southern elephant seals and, to a lesser extent, leopard seals, have been either hooked or entangled in the South Atlantic and South Indian Ocean sectors but these events have remained anecdotal $(<10$ individuals/year across all fishing areas since 2003; CCAMLR, 2018a,b). Sperm whales (Physeter macrocephalus) entanglements in longlines have occurred 8 times since 2007 (5 dead and 3 released alive; CCAMLR, 2009c, 2011, 2012; Richard et al., 2020). Only one killer whale has been recorded hooked and dead on a longline (CCAMLR, 2009a).

Depredation. Depredation, i.e., species feeding on catches directly on the fishing gear, is an operational interaction that has emerged in all Patagonian toothfish longline fisheries over the past 30 years (Kock et al., 2006; Söffker et al., 2015; Tixier et al., 2019a). While Antarctic fur seals and southern elephant seals are involved occasionally (Roche et al., 2007; Söffker et al., 2015; van den Hoff et al., 2017), killer whales and sperm whales most frequently take toothfish from hooks across the Southern Ocean (Kock et al., 2006). Catch depredation by these two species has been reported in all the EEZs of the Southern Ocean (Crespo et al., 1997; Nolan et al., 2000; Hucke-Gaete et al., 2004; Purves and Agnew, 2004; Tixier et al., 2016, 2019a,c; Boonzaier et al., 2012; Janc et al., 2018) and in international waters within the CCAMLR and Southern Indian Ocean Fisheries Agreement areas (Gasco et al., 2019a,b).

Interactions can occur during $>50 \%$ of the fishing operations and result in fish removals equivalent to $>30 \%$ of the total catch (Gasco et al., 2015; Tixier et al., 2020), hence depredation can lead to substantial socio-economic and ecological impacts. While entanglement or bycatch occur sporadically (Kock et al., 2006; Richard et al., 2020), the major threat is the use of firearms or explosives by illegal, unreported and unregulated (IUU) fishing vessels to repel depredating individuals (Guinet et al., 2015). At Crozet, such lethal responses contributed to the $60 \%$ decline of the local killer whale population in the 1990s (Poncelet et al., 2010; Tixier et al., 2017). While IUU fishing activities were greatly reduced after 2003, evidence of a bullet injury on a killer whale at Crozet in 2019 indicates that depredating individuals are still being shot from IUU vessels (C. Guinet, pers. comm.). Depredation may also alter the predatory role of killer and sperm whales in ecosystem functioning through changes in distribution and diet, and artificial provisioning effects on populations (Tixier et al., 2015; Towers et al., 2019).
Discards. Discards (uneaten bait, offal, unwanted non-target fish) from fishing vessels are consumed by many albatrosses and petrels in the Southern Ocean (Cherel et al., 2017; McInnes et al., 2017b), and in more northerly waters during the non-breeding season (Jiménez et al., 2017). In CCAMLR waters, discarding is currently banned in all fisheries south of $60^{\circ} \mathrm{S}$. In toothfish fisheries in the EEZs around subantarctic islands, discarding is prohibited during setting and can only take place during hauling on the opposite side of the vessel. For some species, particularly black-browed albatross, greater consumption of discards has been linked to more extensive overlap with fisheries or higher discard availability around colonies, and also to higher breeding success or breeding frequency among colonies, or across years within the same colony (McInnes et al., 2017b; Pardo et al., 2017).

Fishing gear, and other debris discarded or lost from fishing vessels. Fishing gear (mainly hooks and snoods) lost or deliberately discarded by fishing vessels is ingested in large quantities by albatrosses and large petrels, particularly wandering albatrosses at South Georgia, which frequently scavenge behind vessels especially off South America (Nel and Nel, 1999; Phillips et al., 2010; Cherel et al., 2017). Many hooks fed to chicks are completely digested, but there is no information on possible long-term toxicological effects. A substantial proportion of the non-fishing marine debris (mainly plastics) ingested by wandering albatrosses and southern giant petrels (Macronectes giganteus) at South Georgia also originate from fishing vessels operating outside CCAMLR waters, which has impacts at least at the individual level (Phillips and Waluda, 2020). Discarding is monitored carefully in the toothfish fishery around South Georgia, and marked, vessel-specific hooks are required. Controls are generally weaker elsewhere, and ingestion of anthropogenic items remains a problem for several subantarctic seabirds (Phillips et al., 2010; Phillips and Waluda, 2020).

\section{Food web effects of fishing}

The Antarctic krill fishery currently operates in three distinct locations in the Southern Ocean and is driven primarily by the environmental conditions and local catch limits. During the summer, fishing occurs primarily off the west coast of Coronation Island (South Orkney Islands). Toward the summer's end, the fleet moves into the Bransfield Strait until the catch limit is achieved, and then moves to the waters around South Georgia in winter. The move into the Bransfield Strait coincides with a large influx of male Antarctic fur seals, presumably coming from South Georgia after the summer breeding season, though any potential interactions with the fishery remain unknown (A. Lowther, pers. comm.). In this region, the fishery is extending its activities until the beginning of winter, thus overlapping with the fledging period of three pygoscelid species (during summer, Hinke et al., 2017) as well as with feeding activities of large numbers of humpback whales present in the area until winter (Weinstein et al., 2017).

In areas that experience natural variability in krill abundance, robust evidence exists for an impact on penguin foraging performance (Reid et al., 2005; Waluda et al., 2012, 2017) and baleen whale reproductive success (e.g., Seyboth et al., 2016). Currently catches in the Antarctic krill fishery are $<0.5 \%$ of the estimated regional biomass. However, in recent 
years the fishery has concentrated over specific hotspots where krill dependent predators forage (Santa Cruz et al., 2018). While spatial and temporal overlap has been demonstrated (Santora et al., 2010; Ratcliffe et al., 2015; Hinke et al., 2017; Weinstein et al., 2017) direct evidence that current levels of biomass extraction alter life histories of predators has not been clearly demonstrated. Conversely, Watters et al. (2020) argue there is no evidence that simply having a small catch relative to estimated krill biomass indicates precaution (see section "Integrated Conservation Under Uncertainty and Change"). Only few studies have investigated the overlap between flying seabirds and Antarctic krill fisheries, but one recent study for Antarctic petrels from Dronning Maud Land concluded that competition was negligible (Descamps et al., 2016). CCAMLR has previously recognized that the existing monitoring design would be insufficient for distinguishing between ecosystem changes due to commercial harvesting and changes due to environmental variability (physical or biological; CCAMLR, 2019b,c).

The importance of Antarctic (Dissostichus mawsoni) and Patagonian toothfish in the diet of many predators - and subsequently population-level effects of toothfish biomass removal - remains unclear and understudied. Patagonian toothfish are eaten by both wandering and black-browed albatrosses at Indian Ocean colonies, but only by wandering albatrosses at South Georgia where they overlap with fisheries during the breeding season (Cherel et al., 2000, 2017; Mills et al., 2020); this suggests that toothfish is rarely a natural prey for albatrosses, even if they can be made available by deep-diving seals or cetaceans returning to the surface. Both Patagonian and Antarctic toothfish are natural prey of sperm whales (Yukhov, 1972; Kawakami, 1980), and Patagonian toothfish is important for Crozet killer whales, composing $>30 \%$ of their diet (Tixier et al., 2019b). The extent to which populations of these species were affected by the illegal overexploitation of stocks across the Southern Ocean in the 1990s is not known. In the Ross Sea, Antarctic toothfish is a natural prey of Weddell seals (Ainley and Siniff, 2009) and type-C killer whales (Pitman and Ensor, 2003; Ainley and Ballard, 2012), but spatial and seasonal variation in its importance in diets remain unclear. This uncertainty has generated much debate around the impacts of the toothfish fishery on these species. For example, while overfished toothfish stocks were proposed as responsible for local declines in killer whale sightings (Ainley et al., 2017), to date fine-scale bottom-up effects of fishery extraction on populations have not been evidenced (Pinkerton and Bradford-Grieve, 2014; Pitman et al., 2018).

Large-scale fishing by Soviet fleets from the late 1960s to early 1970s depleted mackerel icefish stocks, as well as marbled (Notothenia rossii) and gray (Lepidonotothen squamifrons) notothenia around subantarctic islands, which had not recovered by the early 2000s (Kock, 2007). These fish were, and mackerel icefish remain, key prey for predators that may have been impacted by the much-reduced stocks of the small notothens after the fisheries collapsed (Waluda et al., 2017). Given the currently low fishing effort for mackerel icefish, and its offshore location, any effects on predators are now very likely to be minor.

\section{Future Threats}

There is growing interest in large mesopelagic organisms (mainly fish and squid) as potentially harvestable resources (e.g., FAO, 2011) and krill fisheries are expanding (Johnston et al., to be published within this research topic) to meet with growing concerns over food security. Lantern fishes (Myctophidae) represent huge resources (estimated between 2 and 19.5 gigatons) available for potential future exploitation for direct human consumption and for aquaculture feed (Hidalgo and Browman, 2019) but their ecology and life histories are little known (St John et al., 2016). As myctophid and krill fisheries use midwater trawl fishing gear (Prellezo and Maravelias, 2019), the threats (direct and indirect interactions) are expected to be expanding in magnitude, as well as extending impact to a different suite of mesopelagic marine predators. However, there is currently no knowledge of how a myctophid fishery would be distributed spatially or temporally, nor what level of biomass extraction would lead to significant food web effects or ecosystem perturbation.

\section{Pollution}

Pollution is broadly defined as the contamination of the environment by substances or compounds that cause harmful health effects. Globally, 1 million new chemicals are formulated annually (Burton et al., 2017), with a proportion of emissions inevitably destined for the polar regions. Despite the remoteness, and the "shielding" nature of oceanic and atmospheric systems surrounding Antarctica (Bengtson Nash et al., 2010, 2017), pollution from lower latitude source regions represents a growing but largely unmonitored threat due to an absence of routine surveillance and measuring systems in Antarctica. In the context of rapidly changing polar climates, pollution is clearly a costressor to wildlife (Fossi and Panti, 2018) with for example, the impacts of poor body condition and pathogens expected to be compounded by accumulated pollutant burdens (Routti et al., 2018). Pollutant categories known to impact Antarctic biota from remote global sources include, but are not limited to synthetic chemicals, heavy metals and macro, micro and nanoplastic debris. Key input pathways of these to the Antarctic region include the atmosphere, ocean currents, in situ usage and biological transport (Bengtson Nash, 2011).

\section{Persistent Organic Pollutants}

Persistent Organic Pollutants (POPs) are a sub-group of organic chemicals that satisfy four criteria: persistence, toxicity, tendency to accumulate in wildlife over time, and magnify between trophic levels; as well as a propensity for longrange transport. While most POPs reach polar regions via the atmosphere, as a function of their persistence and semi-volatility (Wania and Mackay, 1993), perfluoroalkylated substances are proteinophilic (Prevedouros et al., 2006) and hydrophilic, favoring accumulation in surface waters and dispersal via oceanic pathways (Yamashita et al., 2008). In addition, Antarctica supports a number of highly migratory species that can serve as biological "vectors" of chemical transport to the region (Cipro et al., 2018). Finally, increasing human polar activity represents a pollution hazard, with Antarctic research stations identified as 
local emitters of modern POPs (Bengtson Nash et al., 2008; Hale et al., 2008; Wild et al., 2015).

Persistent Organic Pollutants have been identified in Antarctic biota since the 1960s (George and Frear, 1966), including in top predators (Aono et al., 1997; Bustnes et al., 2006, 2007; Waugh et al., 2014; Dorneles et al., 2015; Das et al., 2017). The POP profiles of Antarctic foraging species are typically distinct from northern hemisphere and lower southern latitude counterparts (Bengtson Nash, 2011), reflecting unique, pesticidedominated, hemispheric usage trends, as well as the long-range transport capabilities of individual chemicals (Bengtson Nash et al., 2010). For example whilst ubiquitous in the Southern Ocean, polychlorinated biphenyls (PCBs) do not dominate chemical profiles of predators but Hexachlorobenzene (HCB) and para, para-Dichlorodiphenyldichloroethane (p,p'-DDE) do (Corsolini et al., 2003; Bengtson Nash et al., 2008), with some indication of legacy POP burdens declining in baleen whales over the past three decades (Bengtson Nash, 2018).

As most known POPs accumulate in the lipid reserves of animals, body condition is an important consideration when evaluating POP burden in wildlife, in terms of target tissues, timing for exposure assessment (sampling) and evaluation of toxic effects (Bengtson Nash, 2018). Several studies have investigated potential toxic effects of POP exposure to Antarctic top predators, although this area of research remains challenging due to the uncontrolled nature of testing on larger, freeroaming species. In snow petrels, circulating levels of legacy POPs were positively correlated with levels of the stress hormone corticosterone (Tartu et al., 2015). Similarly, a humpback whale fibroblast cell line has been applied for the in situ investigation of toxicological effect of HCB and p,p'-DDE via immunotoxic, genotoxic and cell integrity endpoints (Burkard et al., 2015, 2019; Maner et al., 2019). Further investment into in vitro approaches is suggested for advancing our understanding of the toxicological sensitivity of Antarctic predators.

\section{Mercury}

Methylation of inorganic mercury Hg (II), mainly by bacteria, produces methylmercury $(\mathrm{MeHg})$, an organic form of mercury that readily biomagnifies in aquatic food webs. $\mathrm{MeHg}$ contributes $50 \%$ of total $\mathrm{Hg}(\mathrm{HgT})$ in Antarctic bottom waters compared to just $5 \%$ of surface waters (Cossa et al., 2011). Accordingly, benthic feeding species (e.g., gentoo penguins) or species consuming benthopelagic species (e.g., wandering albatross) have accumulated some of the highest HgT levels of 21 seabirds from the Kerguelen Islands (2.42 and $4.45 \mu \mathrm{g} / \mathrm{g} \mathrm{dw}$, respectively) (Blevin et al., 2013). Similar findings were made for penguin communities on King George Island (Polito et al., 2016). Further, levels of $\mathrm{HgT}$ varied between 0.004 and $0.8 \mu \mathrm{g} / \mathrm{g} \mathrm{dw}$ in Southern Ocean squid with the pelagic Slosarczykovia circumantarctica and the deep-water species Fillipovia knipovitchi demonstrating the lowest and highest levels, respectively (Seco et al., 2020).

Generally, HgT levels increase with decreasing latitude, with lower levels found in Antarctic phocid species and albatross compared to their temperate or tropical counterparts (Aubail et al., 2011; Cherel et al., 2018). To date Antarctic minke whales are the only Antarctic-foraging cetacean species in which $\mathrm{Hg}$ burdens have been reported, harvested in Japanese commercial whaling operations and Japanese Whale Research Under Special Permit from 1980 to 1999. Considering the bioaccumulative nature of $\mathrm{MeHg}$, the trophic position occupied by cetaceans, and the known $\mathrm{Hg}$ contamination of lower trophic levels (Sontag et al., 2019), this remains a significant research gap. Hg is a known neuro-, immune- and genotoxin (Kershaw and Hall, 2019). Hence, there is significant interest in elucidating the impacts of Hg exposure to Antarctic biota. For instance, heat shock protein transcription in Weddell, Ross and crabeater seals from the Amundsen and Ross Seas negatively correlates with $\mathrm{Hg}$ concentrations in blood (Lehnert et al., 2017). Finally, the endocrine-disrupting and behavioral effects of $\mathrm{Hg}$ were investigated in snow petrels in relation to Hg burdens, with the notable finding that egg-neglect was higher in males with higher Hg burdens (Tartu et al., 2015).

\section{Plastic}

The entanglement of animals in flotsam plastics decreases the survival of individuals by restricting breathing, movement and the ability to successfully feed. Globally, $36 \%$ of seabird species have been documented as entangled by plastic debris (Ryan, 2018). In the Southern Ocean, plastic entanglement has been reported in at least 18 flying seabird (Kühn et al., 2015; Ryan, 2018) and seven penguin species (Ropert-Coudert et al., 2019). Of the world's marine mammal species, $45 \%$ have been documented with cases of entanglement (Gall and Thompson, 2015) highlighting the pollution pressures faced by migratory and resident Antarctic species (e.g., García-Godos et al., 2013).

Plastic debris is ingested by a wide range of marine animals, including top predators (Phillips and Waluda, 2020). There is a lack of data on the exposure to and impacts of plastic ingestion and entanglements on animals in the Southern Ocean (Gall and Thompson, 2015; Provencher et al., 2019). The risks posed by plastics on these species is determined by a variety of life history and environmental drivers such as foraging area or feeding strategy (Fossi et al., 2012; Tavares et al., 2017; Germanov et al., 2018). Seabirds are the vertebrate group for which there is most information on ingestion of marine plastics. For some species, records of plastic ingestion date back almost 30 years (e.g., short-tailed shearwaters Ardenna tenuirostris; Puskic et al., 2020). Albatrosses and petrels present the highest risk (Roman et al., 2019). The high amounts of debris collected by these birds (Phillips and Waluda, 2020) may be linked to their reliance on scent to detect prey that leads them to target bio-fouled plastics (Nevitt et al., 2006; Savoca et al., 2016). Flotsam plastic acts as a matrix that aids in the dispersal of rafting organisms. Biofilms on marine plastics absorb environmentally present chemical pollutants, such as metals and POPs (Johansen et al., 2018; Richard et al., 2019). Additionally, chemical additives used in the manufacturing of plastics can contribute to increased pollutant burden in animals (Lu et al., 2019). For many marine vertebrates, the digestive tract provides a favorable environment for chemical pollutants to leach from ingested plastics (Tanaka et al., 2013, 2015; Coffin et al., 2019). There is growing concern for the combined pressures of plastics and their associated chemical pollutants upon marine wildlife health (Bakir et al., 2016). 


\section{Health and Disease}

Diseases can be introduced to Southern Ocean top predators through human and animal vectors, changing climate, stress and pollutants. On their own, each of these drivers can potentially cause unpredictable effects to predator health; in combination, effects are very likely multiplicative.

Despite much of Antarctica still being considered pristine (Tow and Cowan, 2005; Convey, 2011; Grimaldi et al., 2015), there has been vastly increased human activity in the last two centuries (Frenot et al., 2005; Kerry and Riddle, 2009) including recent exponential increases in Antarctic tourism (see section "On-land Disturbance, Human Impacts and Non-indigenous Species," IAATO, 2019). There is opportunity for disease introduction into relatively naïve populations via anthropogenic introduction of organisms (Lewis et al., 2004; Frenot et al., 2005; Tow and Cowan, 2005; Walton, 2012), in addition to migratory species coming into contact with fauna in more developed regions; a high risk likelihood presents from either (or both) of these threats. It is therefore imperative to address the paucity of data concerning diseases in Antarctic and subAntarctic populations.

Data are lacking on how altered species distributions and interactions due to climate change (Turner et al., 2013) can facilitate the introduction and spread of infectious diseases in the Antarctic. However, the effects of climate and changing species distributions and densities on wildlife disease has already been well-recognized in the Arctic (e.g., Van Hemert et al., 2014; VanWormer et al., 2019) where multiple outbreaks of phocine distemper virus (PDV) were associated with reduction in the extent of sea ice leading to PDV exposure and infection across species of sympatric marine mammals (VanWormer et al., 2019). In Antarctica, extensive research on sea-ice distribution and shifts in top predator movement ecology (e.g., McMahon and Burton, 2005; Massom and Stammerjohn, 2010) now needs to be partnered with investigations into how these changes affect disease prevalence, expression, and transmission.

\section{Introduced Disease and Expanding Range}

Human facilitated movement of pathogens is one of the main contributing causes behind the rise of emerging infectious diseases globally (Voyles et al., 2015). Since the first Antarctic explorations in 1899 birds and mammals have been introduced (see section "On-land Disturbance, Human Impacts and Non-indigenous Species"), as well as human food and body waste products (Kerry and Riddle, 2009) with all the risk for non-indigenous organism introduction this entails (Convey, 2011). While non-native species are no longer wilfully brought to Antarctica, the sub-Antarctic islands are not subject to the environmental protocols of the Antarctic treaty, with quarantine measures and invasive species management enacted by the administering country. This can result in inconsistent and unstandardized management protocols (Jabour, 2009; Walton, 2012).

Current knowledge of diseases in Antarctic species has been largely limited to isolation of viral and bacterial agents in seabirds, at distinct locations and investigations of mass mortality events, rather than any large scale coordinated effort to collect baseline data across multiple spatial scales and species. A review on Antarctic seabirds concluded further research is required to assess pathogen (and parasite) presence, geographical and temporal variation, how this could influence host species and the management required in the event of outbreaks (Barbosa and Palacios, 2009). Two outbreaks of Avian Cholera (Pasteurella multocida) have occurred on the Antarctic peninsula (Leotta et al., 2006), and more recently on subantarctic islands (Gamble et al., 2019). The presence of an evolutionarily distinct lineage of avian influenza virus' (AIVs) in Adélie penguins was discovered in 2013 at the Antarctic Peninsula (Hurt et al., 2014). A new study discovered the presence of 107 viral species in Antarctic penguins; the majority was associated with host diet and ticks (Wille et al., 2020). However, it is unknown whether any of these viruses cause disease in penguins. In 2014, phylogenetic analysis revealed genomic segments of AIVs from both Eurasian and North American lineages in two seabird species (Hurt et al., 2016). These studies demonstrated not only the presence of potentially highly pathogenic agents in just one section of Antarctica, but also a combination of endemic and introduced disease agents. Highlighted by these knowledge "gains" are the unknown consequences that future disease introductions might hold and the huge knowledge gaps remaining to be filled across the continent and its associated islands.

There remain many knowledge gaps on host-parasite relationships in Antarctic faunal assemblages. In seabirds and in marine mammals, ectoparasites and gastrointestinal parasites are the most documented groups (Barbosa and Palacios, 2009; McFarlane et al., 2009). Biting lice, feather mite, flea, tick and helminthes are most frequently recorded among seabirds (Barbosa and Palacios, 2009); amongst mammals, the main organisms are sucking lice, nasal mite, flea and helminths (Murray et al., 1965; Pugh, 1993; McFarlane et al., 2009). The first report of a blood parasite in Antarctica was published recently, when a Babesia sp. was detected in chinstrap penguins (Montero et al., 2016). The only tick species identified in Antarctica, Ixodes uriae, is the probable vector of this Babesia sp., although it has not been confirmed (Montero et al., 2016). Outside Antarctica, I. uriae may also be a potential vector of different protozoans (Peirce and Prince, 1980) and bacteria, as Rickettsia spp. (Chastel et al., 1993). The lack of several blood parasites in Antarctica (e.g., Plasmodium and Haemoproteus) is explained by the absence of appropriate vectors (e.g., mosquitoes, Culicidae) that cannot mature in the region due to the harsh climate conditions (Laird, 1961; Merino et al., 1997). However, environmental changes can modify the context of vectors, parasites and hosts in relation to their development and disease transmission (Patz et al., 2000). A slight temperature increase may be directly related to the augmentation of tick feeding, as found on parasitized penguins at the Antarctic Peninsula in warmer years (limited evidence) (Benoit et al., 2009), and allow the proliferation of potential vectors (Jones et al., 2002) accidentally introduced in the Antarctic ecosystem. 


\section{Animal Stress and Consequences for Health}

Serological evidence of potential disease agents, be they viral, bacterial, protozoal or parasitic, is only one aspect of disease ecology. Human activity, in addition to the potential spread of pathogens (indigenous and translocated), results in increased stress in wildlife populations, which contributes to disease outbreaks (Lafferty and Holt, 2003) and threatens immunocompetence (Tarszisz et al., 2014) via its oftendevastating consequences on the immune system (e.g., Dhabhar, 2009) and can be a significant factor in disease expression. Anthropogenic induced stress occurs through a variety of means, including (but not limited to): physical proximity (tourists and researchers); pollution of the Antarctic environment; nutritional stress; and habitat alteration and fragmentation. Nutritional stress occurs in Antarctic animal populations due to alterations in the abundance and distribution of prey and/or from direct depletion of fish stocks (Grimaldi et al., 2015). Direct anthropogenic-induced stress also occurs from physical proximity to humans (e.g., Engelhard et al., 2001, 2002), which has hastened the rate of non-native microorganism introduction, particularly in ice-free coastal areas where human activities are most prevalent (Tow and Cowan, 2005; Jabour, 2009; Grimaldi et al., 2015). Disease ecology of predator populations, particularly those that fall within the ever-increasing sphere of human activities, requires increasing attention to successfully predict and manage outbreaks.

\section{Migratory Animals as Vectors for Disease Transmission}

Disease and the potential for far-ranging migratory species to act as vectors among different animal populations is a very real risk within MEASO areas. While most Southern Ocean wildlife has evolved in relative seclusion, a number of top predators are migratory species. Seals, cetaceans and albatrosses are wide ranging species (Hindell et al., 2020). The Arctic tern breeds in the Northern hemisphere, but migrates to Antarctica for the austral summer, with the reverse occurring for Wilson's storm petrel (Oceanites oceanicus) (Kerry and Riddle, 2009). Southern elephant seals travel several thousand kilometers during their 10 months at sea (Hindell et al., 2016), and can encounter a range of hosts of common diseases. In several northern phocid species the canine distemper virus (CDV), a morbillivirus with high prevalence throughout the world's dog population (McCarthy et al., 2007), spread throughout populations leading to mass mortalities (Grachev et al., 1989; Kennedy et al., 2000). Serological evidence of CDV has been found in several Antarctic seal species, although no clinical disease has yet presented (Bengtson et al., 1991). Far-ranging migration can therefore increase the risk of disease exposure at distant sites, with the potential for disease transmission to large sections of the population in areas where other species congregate e.g., haul-out sites for southern elephant seals, breeding colonies for seals and birds. Couple these with the ability of diseases to spread more rapidly in marine as opposed to terrestrial populations (McCallum et al., 2003), and the potential for both increased expression of endemic disease and the emergence of new infectious diseases becomes a highly credible threat.

\section{On-Land Disturbance, Human Impacts and Non-indigenous Species}

Species' tolerance to disturbance vary, and disturbance timing and duration are relevant when evaluating impact. For example, disturbance effects can be different during highly sensitive stages in the breeding cycle (e.g., egg laying in seabirds, pre-weaning in marine mammals) making it complex to study. A major challenge is to quantitatively link behavioral and physiological responses to demography and population size. Relying on observations of behavioral changes may be insufficient, as they may not reveal cryptic and long-term effects on populations (Coetzee and Chown, 2016). Here, we broadly discuss land-based impacts and consequences of human-related disturbance mainly on seabirds and seals.

\section{Direct Site Disturbance on Land Including Station Facilities and Tourism}

Disturbance at breeding sites, attacks by natural predators or fights amongst conspecifics are part of life. Human presence, on the other side, is not, and several studies showed a stronger reaction to human disturbance than to natural predators (de Villiers et al., 2005, 2006). For example, repeatedly disturbed penguins experience a reduction in their breeding success (Giese, 1996; Ellenberg, 2017). Also, colonially breeding species are more prone to abandon their nests than solitary breeders. Site disturbance can be transient (e.g., visitations) or physical (destruction of habitat); both can have long-term consequences for populations (Christiansen and Lusseau, 2015). Colonially breeding seabirds and seals are particularly susceptible as they attract attention of both researchers and tourists.

In the Antarctic context, this is particularly important where ice-free, terrestrial habitat suitable for vertebrates is limited and concentrated in coastal regions. It is here where most human activities also occur (Shaw et al., 2014). Across Antarctica, the footprint of all infrastructure and buildings now exceeds $390,000 \mathrm{~m}^{2}$, with an additional disturbance footprint of $>5,200,000 \mathrm{~m}^{2}$ just on ice-free land (Brooks et al., 2019). This footprint is similar in size to the total ice-free area of Antarctica and affects over half of all large coastal ice-free areas, disproportionately concentrating human impacts in some of the most sensitive areas as many species rely on ice-free ground to breed. While the Antarctic Treaty System (ATS) forbids the destruction of colonies, a research station brings with it a variety of disturbance sources ranging from noise of generators, vehicles (terrestrial and marine), aircraft and people to increased visitation of wildlife in the station surrounds. Station personnel and tourists visit concentrations of wildlife near the stations frequently (e.g., Tin et al., 2014) and often throughout the breeding period.

In Antarctica, mainly at the Antarctic Peninsula, visitor numbers (tourists, staff and crew) have been increasing over the last two decades (Liggett et al., 2011; Woehler et al., 2014) to nearly 55,500 people in the 2018/19 summer resulting in over 852,600 individual visits (IAATO, 2019). While not all reported 
visits were to wildlife sites, areas free of human visitation are becoming rarer (Hughes et al., 2011; Liggett et al., 2011), and tourists tend to visit breeding colonies in large groups at a higher frequency than researchers, commonly throughout the breeding season. Although tourists do not always interact with animals directly, both kinds of activities - research and visitation - are types of disturbance but the long-term impact is difficult to measure and is rarely examined (Carey, 2009). A 21-year study of tourist interactions with gentoo penguins has revealed a decline in the Goudier Island population and a reduction in breeding success (Dunn et al., 2019). It also showed a significant link with higher numbers of tourist visitors (from 262 in 1996/1997 to 19,688 in 2016/2017). However, given the complexity of possible drivers, including a significant negative effect of increasing air temperature and shifts in sea ice variables on breeding pairs, the authors recommended both improved management strategies to protect this penguin population, and the initiation of similar studies at other frequently visited penguin sites. Detailed site- and species-specific research can support effective guidelines to develop and implement visitor management; wellmanaged ecotourism can contribute to wildlife conservation (Ellenberg, 2017).

In contrast to tourists, researchers typically work in small teams and may need to capture and handle animals. However, these interactions tend to be time limited and individual animals are typically manipulated once or twice in a season (Wilson and McMahon, 2006; McMahon et al., 2012). Few studies address the consequences of repeated handling, but one investigation of southern elephant seal pups showed no measurable short-term (survivorship) or long-term (fitness) consequences of handling intensity (McMahon et al., 2005). Non-lethal disturbance impacts are often reported as not detrimental with only minor effects, but long-term studies on apparently minor effects of transient disturbance are rare. For example, for eco-physiological studies blood samples are frequently collected, but the long-term effects of this procedure on other aspects of the animals' lives are rarely examined (Angelier et al., 2011). When assessing impacts of researcher disturbance on wildlife, it is important to consider whether previous exposure influences animals' responses. Colonies of some species subjected to long-standing research efforts may over time become less sensitive to human presence than naïve colonies. Cumulative exposure to non-lethal disturbance has been estimated using spatially explicit capturerecapture models (Christiansen et al., 2015) applied to whalewatching boat interactions. Similar approaches could be useful for wildlife populations influenced by the cumulative effects of either a repeated disturbance factor or experiencing several disruptive factors (natural and anthropogenic) simultaneously, as it is important to consider all relevant stress factors that affect animals at the time of study.

\section{Noise Disturbance}

Noise created by human activities occurs both on land and at sea. Fixed wing aircraft and helicopters have increased the range of accessible sites, thereby increasing the human footprint; but few studies have investigated the long-term effects of anthropogenic noise on land. Studies evaluating the immediate impact of helicopters approaching wildlife demonstrated that animals changed behavior, but there was no distinction between visual/acoustic effects (van Polanen Petel et al., 2006 and references therein). The use of wheeled and tracked vehicles on and near stations as well as in the field is widespread but the effects on wildlife are largely unknown. Weddell seals reduced the number of calls they made when over-snow tracked vehicles passed them (van Polanen Petel et al., 2006). While a single event of this nature causes only transient disturbance, the situation is unclear where vehicle operations occur frequently in the same area. The distance between vehicles and wildlife is also important, as is the breeding stage.

Assessment of underwater noise impacts in the Antarctic is an increasingly important issue, primarily related to ship traffic (from tourism, fisheries, and research), but also geophysical research (e.g., seismic surveys) and research station support activities (including construction). A recent review identified marine mammals to be most vulnerable, having the highest auditory sensitivity and using sound for communication, navigation and foraging; reported noise effects included avoidance responses, behavioral changes, disruption of foraging, changes in communication, and death in extreme cases (Erbe et al., 2019 and references therein). Priority research needs to include improved data on marine mammal distribution, hearing sensitivity (e.g., a mysticete audiogram) and assessment of the effectiveness of noise mitigations options. These data can aid refinement of noise exposure criteria for management, assisting the standardization of reasonable noise threshold requirements across countries.

\section{Remote Monitoring via Unmanned Aerial Vehicles}

The use of new technologies such as unmanned aerial vehicles (UAVs) is spreading rapidly and is expected to make wildlife monitoring less disruptive and more cost effective (e.g., Muller et al., 2019; Nowak et al., 2019). However, research on the potential impact of UAVs on wildlife is still preliminary (e.g., Rümmler et al., 2018; Weimerskirch et al., 2018) and potential long-term effects remain poorly understood. UAVs have quickly become a mainstream activity (Šimek et al., 2017). IAATO introduced a moratorium on recreational UAV flights in coastal areas (IAATO, 2015) and recorded the number of flights on IAATO registered vessels. In 2014/15, some 89 UAV flights were reported and in 2018/19 the number had risen to 1984 (IAATO, 2019) of which $95 \%$ were of commercial nature and less than $2 \%$ were for scientific purposes.

Currently, logistical and operational activities benefit from the use of UAVs, but information of UAV use in non-IAATO linked tourism and other commercial or scientific operations is largely absent. Issues near wildlife include the risk of accidents, aircraft flying too low over wildlife concentrations, and the potential number of UAVs flying under no limitations. Therefore, in 2018, comprehensive environmental guidelines for UAV usage in Antarctica were drafted and adopted by the ATS Parties to help avoid and/or reduce disturbance to wildlife while allowing for beneficial use (Harris et al., 2019). To our knowledge there are no equivalent guidelines for operation of unmanned underwater 
vehicles used for observing wildlife (e.g., Clarke and Tyler, 2008) or other purposes.

\section{Non-indigenous (Introduced and Invasive) Species}

Antarctica and the sub-Antarctic islands have no native land mammals; deliberate or accidental introductions occurred when the islands were exploited for their natural resources (Russ, 2007; Convey, 2011). The response of island fauna was complex and variable. While non-native predators caused extinction of some endemic species (e.g., Taylor, 1979; Holdaway et al., 2010), not all introductions increased the mortality of local wildlife populations. For example, at New Island, Falkland Islands, introduced rodents and cats appear to coexist without a major impact on the local seabird populations; the cats (Felis catus) prey mainly on rodents (Quillfeldt et al., 2008).

Most commonly, increased mortality among native vertebrate populations has been caused directly or indirectly by rats (Rattus rattus), mice (Mus musculus), cats and rabbits (Oryctolagus cuniculus). Rodents inflict significant injury and mortality among seabirds, including albatross chicks (Wanless et al., 2007; Jones and Ryan, 2010; Dilley et al., 2016). As the birds evolved without the presence of natural terrestrial predators, they are ill suited to defend themselves (Frenot et al., 2005). For critically endangered species such as the Tristan albatross (Diomedea dabbenena; Wanless et al., 2007, 2009) chick mortalities compound the albatross deaths in longline fisheries and worst-case scenario modeling predicts species extinction in $\sim 30$ years; effective mitigation of both fishery mortality and mouse predation impacts is required (Wanless et al., 2009).

Mice adapted well to local conditions on many sub-Antarctic islands. At Marion Island, they reached densities of $>150$ mice $\mathrm{ha}^{-1}$ (Matthewson et al., 1994). Cats were eradicated here in the 1990s (Jones and Ryan, 2010; Jones et al., 2019). Since 2003, mouse attacks on albatrosses (including fatally) have been noted. Mice also predated incubating adults at Gough Island where mouse densities are $\sim 280$ mice ha $^{-1}$ (Parker et al., 2016; Jones et al., 2019).

At Macquarie Island, rabbits significantly reduced breeding habitat of burrowing seabirds whose populations declined markedly. In 2010-12, rabbits and rodents were eradicated, and many seabird populations improved (Springer, 2018). Similarly, at the Kerguelen Archipelago, seabird populations rebounded post-eradication of rabbits some increasing 4- to 8-fold (Brodier et al., 2011).

Introductions of non-native mammals to the Antarctic continent are currently unlikely as the environmental conditions are unsuitable for most non-native species (Woehler et al., 2014).

\section{INTEGRATED CONSERVATION UNDER UNCERTAINTY AND CHANGE}

Many factors directly or indirectly threaten top predators (Table 3) and substantial gaps in information and governance capacity remain (Box 2 and Table 4). For example, population estimates for many predator species are imprecise, or out of date, in some cases by several decades (e.g., Phillips et al., 2016;
Trathan et al., 2019). Estimates of population trend might exist at some of the better-known breeding sites, but regional or global estimates for many species are insufficient for accurate assessment of change driven by factors threatening predators. To inform management in the face of these threats, a better understanding of the potential causative mechanisms that shape population size, demography, phenology, distribution, diet and behavior is urgently needed along with more comprehensive and integrated management. This section explores the challenges and opportunities that scientists and policymakers face in the implementation of adequate measures for conserving top predators (Table 5).

Governance of Southern Ocean top predators occurs through a wide suite of legal instruments and associated regulatory bodies (Table 4) and through regional fisheries management organizations (RFMOs) adjacent to the CCAMLR area. While the IWC, CCAS and RFMOs primarily take a single-species approach in the management of predators, CCAMLR has a unique ecosystem and precautionary mandate toward conservation (see section "Southern Ocean Fisheries Interactions"). The Madrid Protocol (1991) also establishes an obligation to provide suitable protection to top predators as species-specific or system-wide measures. Other international bodies have a remit that covers the Southern Ocean and may provide opportunities for developing measures to support top predator conservation, such as ACAP.

Climate change related threats to Southern Ocean top predators are global in nature, thus requiring coordination across management bodies (Rintoul et al., 2018; Chown and Brooks, 2019). While the global threats are managed by the United Nations Framework Convention on Climate Change, an opportunity exists for CCAMLR and the Antarctic Treaty Parties to incorporate recommendations coming out of United Nations bodies such as the IPCC. For example, the SROCC (IPCC, 2019) highlights several urgent issues of significance to managing Southern Ocean ecosystems, including changes in sea-ice advance/retreat and related impacts on ice-dependent top predators, as well as potential effects of climate related drivers on food web structure and function, biodiversity and fisheries. Furthermore, the report emphasized that governance arrangements in the polar regions are currently not sufficient to adequately address the projected risks (IPCC, 2019). In light of this report, during the CCAMLR annual meeting in 2019, some members recalled CCAMLR Resolution 30/XXVIII on climate change (CCAMLR, 2009b), noting that it was timely to update the 2009 resolution, yet despite extensive discussions no agreement followed (CCAMLR, 2019a; paras 8.11 to 8.16). Over recent years, some CCAMLR parties have pursued related initiatives, such as a Climate Change Response Work Program that specifies actions to manage the Southern Ocean ecosystem more effectively under climate change. However, despite having a dedicated agenda item toward discussing climate change, these initiatives have been stalled by difficulties in reaching consensus (Rayfuse, 2018). The Committee for Environmental Protection - which provides recommendations to the Antarctic Treaty Parties for carrying forward provisions regarding the Environmental Protocol - has also developed a similar program and is progressing (CEP, 2019), but at a pace much slower than that of climate-related changes. The issues identified here and 


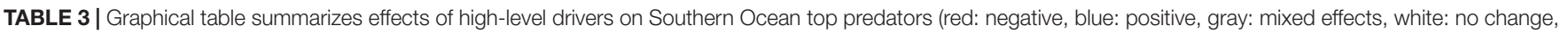
black: data required) with confidence indicated as $\bullet \bullet \bullet$ high, $\bullet$ medium, $\bullet$ low.
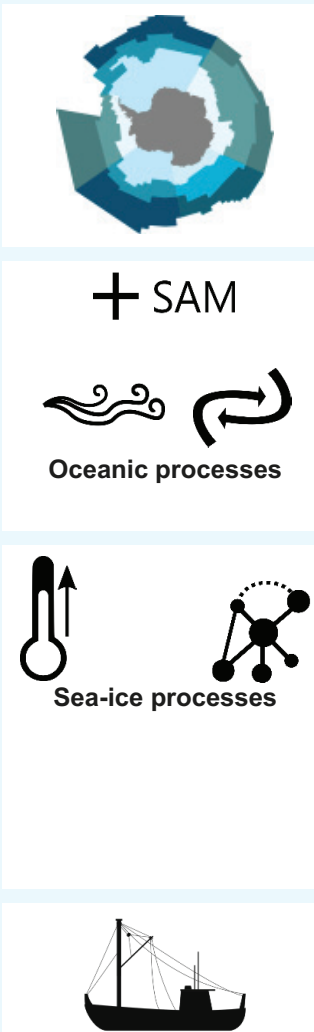

Fisheries interactions

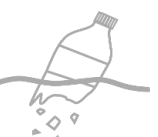

Global pollution

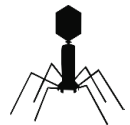

Health and disease

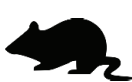

Land-based disturbance

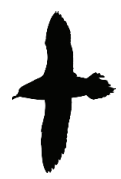

Flying seabirds
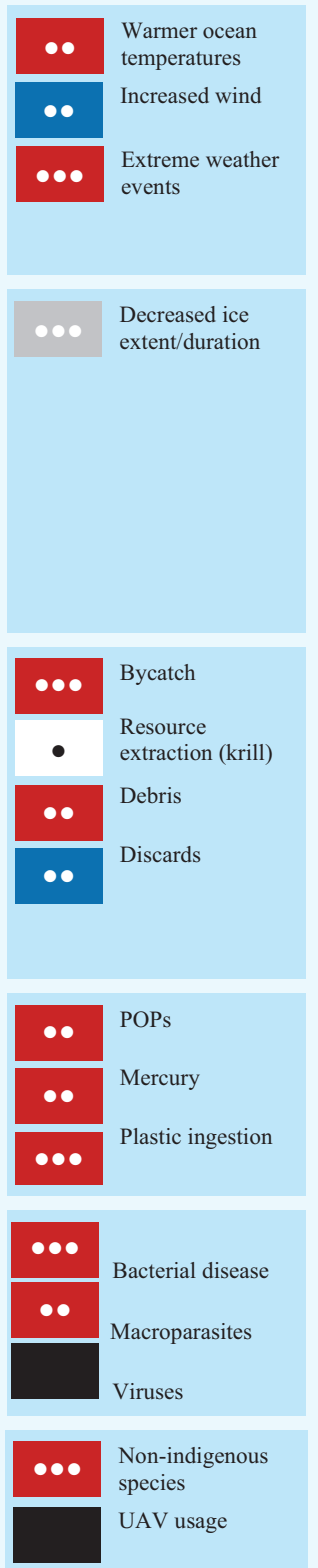

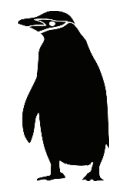

Penguins
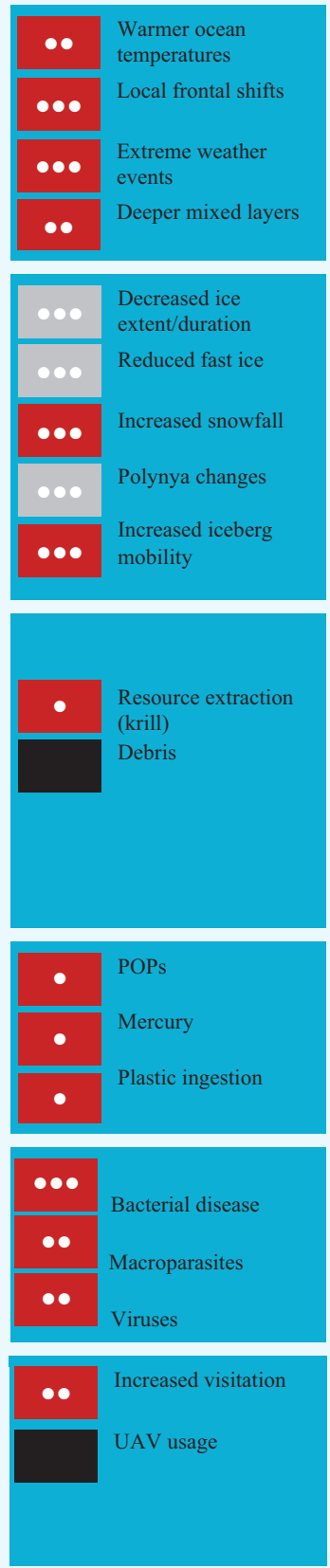
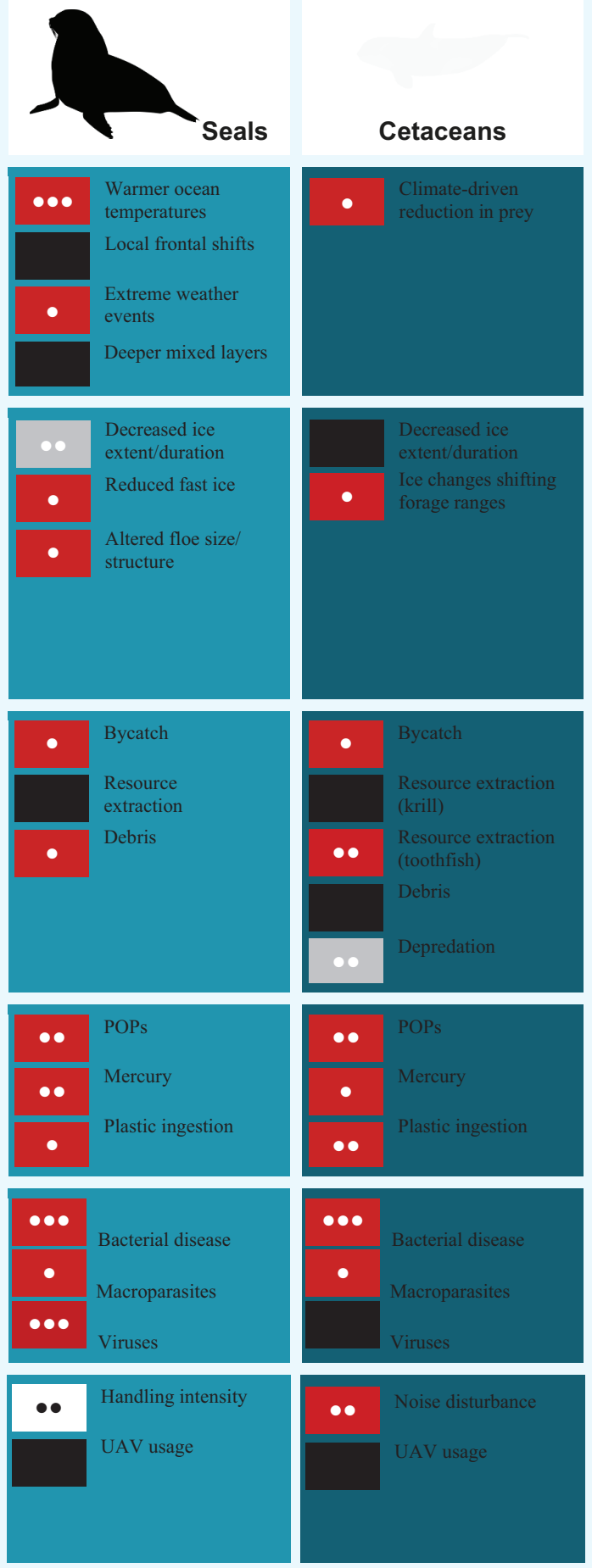

See text for commentary on the capability of current monitoring to be able to detect effects.

throughout this paper need to be urgently factored into CCAMLR and the Antarctic Treaty Consultative Parties precautionary approaches (Hughes et al., 2018).
The management of indirect interaction and effects on top predators is undertaken in two ways: a systems approach and an approach to reduce resource competition. One systems 
BOX 2 | Research gaps and priorities.

\section{Data coverage}

Top predators receive considerable study effort and arguably represent the taxa for which the most ecological information is available. Yet, significant gaps remain at geographic (away from the main study sites and in vast Southern Ocean expanses), species (cryptic cetacean species) or life stage (juveniles) levels. Routine population censuses are spatially very limited, and population estimates for many predator species are imprecise, or out of date. Observational data remain sparse and difficult to collect during winter, especially within the sea-ice, hampering understanding of processes shaping predator-prey interactions in polynyas or under the ice. In oceanic areas, we are improving our understanding of the role of physical oceanic structures (eddies, filaments, fronts) in shaping the prey field distribution and hence predator foraging success. Further work should prioritize quantifying relationships (and their uncertainty) between key biological parameters (population growth rate, mortality, breeding success, migration phenology) and their biophysical drivers, to improve predictive capacity.

Given that top predators integrate signals over various spatiotemporal scales, we can take advantage of this through use of bio-logging and bio-monitoring technologies. Scaling up from such observations to synoptic predictive modeling represents an important strategy to overcoming monitoring limitations.

\section{Projections of future change}

Our understanding of current ocean/climate - prey - predator links and dependencies is inadequate. This is especially important for projecting how environmental changes will affect predator populations, but also for disentangling changes related to climate from changes with other causative mechanisms, such as fisheries. Meso- and fine-scale ocean features and biological coupling are not well-resolved in most earth system models. This limits the realism in modeling and projecting biotic interactions. Notably it is also complex to project socio-economic components.

Over the coming decade, we can expect higher resolution forecasting, and improved coupling (ocean-ice, physics-biology), which can better resolve features influencing predators and their prey. Alongside, we need to improve our characterization of linkages between ocean/climate, prey and predators. While a lot of attention has been given to krill-predator interactions, the importance of other prey, like toothfish or myctophids, deserves increased attention, as these become potential targets for commercial fisheries. Other key habitat requirements, notably fast ice (critical for some species life stages), remain poorly represented within both observational and modeled products.

\section{Identification and management of current and future risks}

While outside the direct scope of MEASO, gaps in understanding the connectivity of the Southern Ocean with the rest of the planet (Murphy et al., to be published in this research topic) pose major threats to our ability to protect it. Management bodies like CCAMLR have made extensive efforts to limit by-catch for example, but these best practices stop at the CCAMLR administrative boundaries, while some species distribute far beyond them. Governance for conservation of top predators requires coordination across management bodies. Also, a renewed commitment to progressing work programs specifying actions to manage the Southern Ocean ecosystem more effectively under climate change, and adequately addressing the projected risks for species and the ecological systems upon which they depend.

Similarly, administrative boundaries are porous to invasive species, introduced pathogens and their possible role in emerging diseases, or pollution. These increasingly influential and multiplicative threats deserve specific attention, as little is known, for instance, on the toxicological sensitivity of Antarctic predators to POPs and mercury, but also the real extent of plastic pollution and its impact. Growing human presence and activities, e.g., through tourism, requires studies to carefully investigate how disturbance, including exposure to a diversified and amplified soundscape, may affect predators long-term.

So, how to address these gaps and challenges? Clearly, additional funding is always a benefit, but this could be targeted toward goals that are often not at the core of funding schemes. Long-term monitoring has proved an invaluable requirement to examine the inter-connected climatic and anthropogenic effects. However, this cannot solely be maintained by limited research resources. To this end, and in parallel to researcher positions, dedicated long-term positions for "monitoring scientists" should be created - a commitment that would also increase work opportunities for many talented early career scientists. With such a task force, long-term monitoring sites could be expanded. The continued improvement in remote technologies (including satellite censusing, drones, underwater moorings, animal-borne environmental samplers), should also form an efficient and core part of continuous monitoring, implemented wherever needed to upgrade monitoring programs. It is also crucial to promote the recent trend in scaling up from individual projects toward multi-site, multi-species synthesis studies, as these are the only possibility to obtain synoptic views and understanding of these ecosystems.

approach to managing for multiple stressors is through the establishment of marine protected areas (MPAs). CCAMLR has established two MPAs to date - one near the South Orkney Islands $\left(\sim 94,000 \mathrm{~km}^{2}\right)$ and one of the world's largest in the Ross Sea $\left(>1.55\right.$ million $\left.\mathrm{km}^{2}\right)$. There are also multiple large MPAs in subantarctic island Exclusive Economic Zones (see Brooks et al., 2020), established partly to provide protection for top predators (see Trathan et al., 2014; Trathan and Grant, 2020). However, Hindell et al. (2020) assessed the locations of predator hot spots in the Southern Ocean and examined how these are expected to change under climate scenarios. They compared these locations to the established and proposed marine protected areas in the region and concluded that further MPAs are needed to provide for the long-term requirements of these predators, including the existing proposals before CCAMLR as well as other areas. The protected areas system remains largely unsystematic and underdeveloped (Hughes and Grant, 2017; Brooks et al., 2020).

Beyond CCAMLR, Annex V of the Environmental Protocol to the Antarctic Treaty enables the Parties to designate Antarctic Specially Protected Areas (ASPAs) to protect environmental values, including areas with important or unusual assemblages of species, like major breeding colonies of seabirds or mammals (Environmental Protocol, 1991). ASPAs are primarily on land; some include a limited at-sea portion, for which CCAMLR is consulted, and comprise all colonies of one or more bird species (Wauchope et al., 2019). Given the threats to top predators, MPAs and ASPAs provide an important tool to help mitigate impacts. A stronger connection between ASPAs (Antarctic Treaty) and MPAs (CCAMLR) is desirable to enhance protection of species that use both domains.

Under Annex II to the Protocol, vulnerable species can be designated as Antarctic Specially Protected Species (SPS) (Environmental Protocol, 1991). Designating species facilitates protection across all life history stages and eventually of all genetically distinct meta-populations (Trathan et al., 2020). Currently, no species has yet been designated an Antarctic SPS; however, designation should in theory mitigate any human activities that might harm candidate species. The relationship between CCAMLR and the Antarctic Treaty would also ensure consistency in the application of such measures by CCAMLR. Work to consider possible designation of emperor penguins 
TABLE 4 | Regulatory bodies with responsibility for conserving Southern Ocean marine predators, particularly with respect to the main threats shown in Table 3, i.e., climate change, fisheries interactions, global pollution, health and disease and land-based disturbance.

\begin{tabular}{|c|c|c|c|c|}
\hline Legal Instrument & Regulatory body & Responsibility & Approach & Information needs and gaps \\
\hline $\begin{array}{l}\text { International Convention on } \\
\text { the Regulation of Whaling }\end{array}$ & $\begin{array}{l}\text { International Whaling } \\
\text { Commission }\end{array}$ & Conservation of whales & $\begin{array}{l}\text { Historical catch quotas; modern } \\
\text { moratorium; Southern Ocean Whale } \\
\text { Sanctuary; population assessments. }\end{array}$ & $\begin{array}{l}\text { Status of Southern Ocean whales (including } \\
\text { abundance, trend and past catches), including } \\
\text { under environmental change (and fisheries indirect } \\
\text { interactions). }\end{array}$ \\
\hline $\begin{array}{l}\text { Antarctic Treaty and the } \\
\text { Protocol on Environmental } \\
\text { Protection to the Antarctic } \\
\text { Treaty }\end{array}$ & $\begin{array}{l}\text { Antarctic Treaty } \\
\text { Consultative Meeting and } \\
\text { Committee for } \\
\text { Environmental Protection }\end{array}$ & $\begin{array}{l}\text { Environmental protection of the } \\
\text { Antarctic continent and the seabed }\end{array}$ & $\begin{array}{l}\text { Antarctic Specially Protected } \\
\text { Areas/Species; Prohibitions of taking or } \\
\text { harming Antarctic species; Prohibitions } \\
\text { of introducing non-native species; } \\
\text { Environmental impact assessments for } \\
\text { science bases. }\end{array}$ & $\begin{array}{l}\text { Population status and trends of many species } \\
\text { unclear; biodiversity assessments needed; } \\
\text { insufficient regulations for managing some threats } \\
\text { (e.g., pollution from global sources, disease and } \\
\text { tourism). }\end{array}$ \\
\hline
\end{tabular}

$\begin{array}{lll}\begin{array}{l}\text { The Convention for the } \\ \text { Conservation of Antarctic } \\ \text { Seals (CCAS) } \\ \begin{array}{l}\text { Agreement on the } \\ \text { Conservation of } \\ \text { Albatrosses and Petrels }\end{array}\end{array} & \begin{array}{l}\text { N/A (currently no } \\ \text { commercial sealing) }\end{array} & \begin{array}{l}\text { Conservation of Antarctic seals } \\ \text { Meeting of the Parties }\end{array} \\ \begin{array}{l}\text { Convention on the } \\ \text { Conservation of Antarctic } \\ \text { Marine Living Resources }\end{array} & \begin{array}{l}\text { Commission for the } \\ \text { Conservation of Antarctic } \\ \text { Marine Living Resources }\end{array} & \begin{array}{l}\text { Conservation of Albatrosses and Petrels } \\ \text { Cosources, including fished species as } \\ \text { rell as the ecosystem more broadly }\end{array}\end{array}$

Catch regulations (and prohibitions), protected species and protected areas.

Population status, including under environmental change.

Coordination of international activities:

Recommendations for seabird

mitigation measures, management and protection of breeding sites.

Catch quotas; Ecosystem approach to management; Mitigation measures to avoid birds and mammals; Protected areas; Climate chang resolutions/measures.

Mitigation measures to avoid birds and

$\begin{array}{lll}\begin{array}{l}\text { Conventions related to Tuna } \\ \text { and other fished species }\end{array} & \begin{array}{l}\text { Regional Fisheries } \\ \text { Management Organizations } \\ \text { (RFMOs) }\end{array} & \begin{array}{l}\text { Conservation of marine living resources } \\ \text { (including ecosystems) adjacent to the } \\ \text { CCAMLR Area }\end{array}\end{array}$

Accurate population status of many species unknown; Effective seabird mitigation lacking in a number of RFMOs leaving Southern Ocean albatross and petrel populations at risk. Lacking adequate knowledge of ecosystem impacts (direct/indirect) from fishing as well as impacts from climate change.

Lacking adequate compliance mechanisms to mitigate seabird bycatch. 
TABLE 5 | Key messages arising from this chapter.

\section{Key Messages}

1. In the Southern Ocean, top predators provide some of the best long-term datasets and, hence, capacity to address issues dealing with climate change.

2. Climate change is an overarching threat that acts independently and/or in combination with other threats, especially fisheries, but disentanglement of effects remains key to defining and evaluating conservation measures.

3. Many subantarctic seabird populations remain threatened despite existing fisheries mitigation measures, requiring improved practices beyond CCAMLR waters (high confidence).

4. Global pollutants increasingly impact Southern Ocean biota, and long-range migrations by top predators can favor transport of pollutants, invasive species and diseases (low confidence).

5. Emerging health and stress indices show promising capacity for top predators to provide monitoring of ecosystem change (medium confidence).

6. As human activities - tourism and research - increase so does the potential for direct disturbance impacts particularly in ice-free coastal regions (high confidence); management mechanisms must continue to evolve to mitigate these.

7. Risk-assessment frameworks that explicitly account for predator consumption, including recovering baleen whale populations, are a critical new tool for allocating spatial (krill) catches.

8. Similar approaches integrating across differing Southern Ocean management responsibilities are necessary to coordinate responses to the accelerated pace of climate-related change.

is underway (Trathan et al., 2020), given its vulnerability to environmental changes and related dire population projections (e.g., Jenouvrier et al., 2019).

One ongoing major threat, especially to flying seabirds, is incidental mortality in industrial fisheries. While CCAMLR has successfully eliminated, or at least reduced to very low levels, the mortality of seabirds in longline fisheries, this issue remains a challenge for longline and trawl fisheries outside of the CCAMLR Convention Area. One solution might be more outreach and coordination from CCAMLR to adjacent RFMOs. This could include sharing strategies on seabird bycatch mitigation measures and encouraging more direct action or coordination with ACAP.

Beyond threats of direct interactions, a challenge in implementing true ecosystem-based management is to reduce the effects of resource competition between a fishery and top predators, particularly for the krill fishery. While a requirement under CCAMLR, fisheries are still managed under a singlespecies stock assessment approach. This approach has thus far only provided for predators in setting the catch limits of krill. It has not yet been able to effectively and directly incorporate spatial impacts on predator and prey and environmental changes. This latter need has been demonstrated by a hierarchical model using 30 + years of penguin monitoring data, which revealed that penguin performance was reduced when local harvest rates exceeded relatively low thresholds (Watters et al., 2020). This effect was similar in magnitude to that of poor environmental conditions, suggesting that even relatively small catch limits may not be precautionary for their predators. Measuring these impacts are a tremendous challenge and wrought with uncertainty. Predators respond to many drivers, including but not limited to environmental conditions and predators' interactions. However, lack of evidence does not mean lack of impact.

The commission for the Conservation of Antarctic Marine Living Resources has made strides in the last year by agreeing to an advanced management strategy for krill that would include not only a stock assessment, but also regular updates of biomass estimates and a risk assessment framework to inform the spatial allocation of catch (CCAMLR, 2019c, para 5.17). The risk assessment framework would include consideration of the spatial foraging needs of predators, including accounting for the ongoing recovery and modeling.

The development of the risk framework, while demonstrating progress in CCAMLR's ecosystem approach, exemplifies the need for integration, in this case between the Scientific Committees of CCAMLR and the IWC. The krill risk assessment framework (SC-CAMLR, 2016, 2019) will necessarily incorporate up-todate whale density and abundance data into models of krill consumption by predators (e.g., Kelly et al., 2018; Trathan et al., 2019; Warwick-Evans et al., 2019a,b). The IWC's Scientific Committee oversees the population assessments of whales, recording data on abundance and trends, validating statistical analyses of whale abundance and recovery, and assessing environmental and anthropogenic threats. Both CCAMLR and IWC Scientific Committees recognize that improved engagement between these intergovernmental organizations could support CCAMLR in achieving ecosystem assessment objectives. Initiatives in planning to assist with this include a Cetacean Subgroup within CCAMLR's Scientific Committee, a joint workshop on Southern Ocean ecosystem modeling (IWC, 2017 p56; SC-CAMLR, 2018 p7.12) and a joint IWC-CCAMLR workshop (IWC, 2018). For populations of conservation concern, the IWC implements Conservation Management Plans, providing a framework to protect and rebuild depleted populations through coordinated collaboration of countries spanning their range. Two such populations (southeast Pacific and southwest Atlantic right whales) can also range into the Southern Ocean (the Bellinghausen/western Antarctic Peninsula region, and Scotia Arc/northern Weddell Sea, respectively). Antarctic blue whales are also classified as Critically Endangered on the IUCN Red List. Explicit consideration of possible impacts on these depleted populations should be considered within CCAMLR's ecosystem management framework.

Efforts to reduce interactions with land-based colonies have been occurring throughout the Antarctic Treaty System. 
For example, SCAR and IAATO are currently leading a systematic conservation planning project, to inform on how to optimally manage biodiversity, science and tourism. Antarctic tourism has increased dramatically in the last two decades. The decline in Goudier Island gentoo penguins (see section "Direct Site Disturbance on Land Including Station Facilities and Tourism") is in contrast to less visited sites elsewhere in the region (Dunn et al., 2019) and to the core objectives of IAATO, i.e., ensuring that tourism has no more than a minor or transitory impact on the Antarctic environment (IAATO, 2019). In 2019, the Netherlands and the United Kingdom convened a workshop on Antarctic tourism, attended by many parties and IAATO, and produced multiple recommendations to the Antarctic Treaty Consultative Meeting (ATCM, 2019) which were agreed. These recommendations included work between Parties, COMNAP, SCAR and IAATO to ensure that current Antarctic visitor guidelines are in line with best practice, levying of an administrative fee which could be used to support environmental monitoring of areas visited by tourists, development of a standard framework for assessing the safety and environmental impact of new tourism activities, and to improve and standardize rules compliance among the parties involved in Antarctic tourism.

Overall, the institutions with responsibility for conserving Southern Ocean top predators must manage for those priority species with a listed status of concern, as well as more broadly for direct and indirect (including food web) effects on predators. However, the paucity of information on the status of many species coupled with ongoing threats poses a significant management challenge. Further, the Southern Ocean lacks institutions that are directly responsible for the control of pollution, disease, tourism and other threats highlighted above. All the above-mentioned tools and approaches, and others (Table 5), need to be used swiftly and in creative ways given the accelerated pace of climaterelated change in the world's oceans (Tittensor et al., 2019).

\section{AUTHOR CONTRIBUTIONS}

SoB and YR-C coordinated the project, and assembled and edited the manuscript. All authors wrote the content, with specific contributions as outlined below, provided review and edits across the manuscript, and approved the final version. YR-C and SoB: sections "Abstract" and "Introduction". RR, YR-C, and JJ:

\section{REFERENCES}

Ainley, D., Ballard, G., Ackley, S., Blight, L. K., Eastman, J. T., Emslie, S. D., et al. (2007). Paradigm lost, or is top-down forcing no longer significant in the Antarctic marine ecosystem? Antarct. Sci. 19, 283-290. doi: 10.1017/ $5095410200700051 X$

Ainley, D., Russell, J., Jenouvrier, S., Woehler, E., Lyver, P. O. B., Fraser, W. R., et al. (2010). Antarctic penguin response to habitat change as Earth's troposphere reaches $2^{\circ} \mathrm{C}$ above preindustrial levels. Ecol. Monogr. 80, 49-66. doi: 10.1890/ 08-2289.1

Ainley, D. G., and Ballard, G. (2012). Trophic interactions and population trends of killer whales (Orcinus orca) in the Southern section "Data, Methods and Tools". PPi, CC, MW, SL, and AF: section "Influence of Climate Change on Marine Predators". AL, PT, and RP: section "Interactions With Commercial Fisheries and Resource Extraction". SuB and PPu: section "Pollution". MD, CM, AR, and ET: section "Health and Disease". BW and SoB: section "On-Land Disturbance, Human Impacts and Nonindigenous Species". CB, PT, JJ, and MS: section "Integrated Conservation Under Uncertainty and Change".

\section{FUNDING}

SoB is supported by Australian Research Council DECRA DE180100828. PT is supported by Australian Research Council LP160100329. We thank the WWF-UK for financial support during the original workshop and to RR and YR-C.

\section{ACKNOWLEDGMENTS}

We thank Monica Muelbert for early input on the project scope and Mark Hindell who provided advice on experts for authoring specific subject sections. We are grateful to Mark Belchier for useful discussion on CCAMLR fisheries. Ben Raymond kindly supplied the colony size data from Hindell et al. (2020) presented in Figure 3, as compiled under the SCAR Retrospective Analysis of Antarctic Tracking Data project. This work is a core contribution to the first Marine Ecosystem Assessment for the Southern Ocean (MEASO) of IMBeR's program ICED. We thank the MEASO Support Group and Steering Committee for assisting with figures, coordination and editing of the text. Andrew Constable provided valuable comments that helped improve an earlier version of this manuscript, particularly section "Integrated Conservation Under Uncertainty and Change". Stacey McCormack provided the graphics support for developing Figures 1, 2 and Table 3. We also thank our reviewers for their constructive and helpful comments.

\section{SUPPLEMENTARY MATERIAL}

The Supplementary Material for this article can be found online at: https://www.frontiersin.org/articles/10.3389/fevo.2020. 566936/full\#supplementary-material

Ross Sea. Aquat. Mamm. 38, 153-160. doi: 10.1578/AM.38.2.20 12.153

Ainley, D. G., Clarke, E. D., Arrigo, K., Fraser, W. R., Kato, A., Barton, K. J., et al. (2005). Decadal-scale changes in the climate and biota of the Pacific sector of the Southern Ocean, 1950s to the 1990s. Antarct. Sci. 17, 171-182. doi: 10.1017/S095410200500 2567

Ainley, D. G., Lindke, K., Ballard, G., Lyver, P. O. B., Jennings, S., Toniolo, V., et al. (2017). Spatio-temporal occurrence patterns of cetaceans near Ross Island, Antarctica, 2002-2015: implications for food web dynamics. Polar Biol. 40, 1761-1775. doi: 10.1007/s00300-017-21 $00-9$ 
Ainley, D. G., and Siniff, D. B. (2009). The importance of Antarctic toothfish as prey of Weddell seals in the Ross Sea. Antarct. Sci. 21, 317-327. doi: 10.1017/ S0954102009001953

Allan, E. L., Froneman, W. P., Durgadoo, J. V., McQuaid, C. D., Ansorge, I. J., and Richoux, N. B. (2013). Critical indirect effects of climate change on subAntarctic ecosystem functioning. Ecol. Evol. 3, 2994-3004. doi: 10.1002/ece3. 678

Amaral, A. R., Loo, J., Jaris, H., Olavarria, C., Thiele, D., Ensor, P., et al. (2016). Population genetic structure among feeding aggregations of humpback whales in the Southern Ocean. Mar. Biol. 163:132. doi: 10.1007/s00227-016-2904-0

Ancel, A., Horning, M., and Kooyman, G. L. (1997). Prey ingestion revealed by oesophagus and stomach temperature recordings in cormorants. J. Exp. Biol. 200, 149-154.

Andrews-Goff, V., Bestley, S., Gales, N. J., Laverick, S. M., Paton, D., Polanowski, A. M., et al. (2018). Humpback whale migrations to Antarctic summer foraging grounds through the southwest Pacific Ocean. Sci. Rep. 8:12333. doi: 10.1038/ s41598-018-30748-4

Angelier, F., Weimerskirch, H., and Chastel, O. (2011). Capture and blood sampling do not affect foraging behaviour, breeding success and return rate of a large seabird: the black-browed albatross. Polar Biol. 34, 353-361. doi: 10.1007/s00300-010-0888-7

Aono, S., Tanabe, S., Fujise, Y., Kato, H., and Tatsukawa, R. (1997). Persistent organochlorines in minke whale (Balaenoptera acutorostrata) and their prey species from the Antarctic and the North Pacific. Environ. Pollut. 98, 81-89. doi: 10.1016/S0269-7491(97)00105-X

Arcalís-Planas, A., Sveegaard, S., Karlsson, O., Harding, K. C., Wåhlin, A., Harkonen, T., et al. (2015). Limited use of sea ice by the Ross seal (Ommatophoca rossii), in Amundsen Sea, Antarctica, using telemetry and remote sensing data. Polar Biol. 38, 445-461. doi: 10.1007/s00300-014-1602-y

Arthur, B., Hindell, M., Bester, M., De Bruyn, P. N., Goebel, M. E., Trathan, P., et al. (2018). Managing for change: using vertebrate at sea habitat use to direct management efforts. Ecol. Indic. 91, 338-349. doi: 10.1016/j.ecolind.2018.04. 019

Arthur, B., Hindell, M. A., Bester, M. N., Oosthuizen, W. C., Wege, M., and Lea, M. A. (2016). South for the winter? Within-dive foraging effort reveals the trade-offs between divergent foraging strategies in a free-ranging predator. Funct. Ecol. 30, 1623-1637. doi: 10.1111/1365-2435.12636

ATCM (2019). Final Report of the Forty-Second Antarctic Treaty Consultative Meeting, Vol. 1. Prague: ATCM.

Atkinson, A., Hill, S. L., Pakhomov, E. A., Siegel, V., Reiss, C. S., Loeb, V. J., et al. (2019). Krill (Euphausia superba) distribution contracts southward during rapid regional warming. Nat. Clim. Change 9, 142-147. doi: 10.1038/s41558-0180370-z

Attard, C. R., Beheregaray, L. B., and Möller, L. M. (2016). Towards populationlevel conservation in the critically endangered Antarctic blue whale: the number and distribution of their populations. Sci. Rep. 6:22291. doi: 10.1038/srep 22291

Aubail, A., Teilmann, J., Dietz, R., Rigét, F., Harkonen, T., Karlsson, O., et al. (2011). Investigation of mercury concentrations in fur of phocid seals using stable isotopes as tracers of trophic levels and geographical regions. Polar Biol. 34, 1411-1420. doi: 10.1007/s00300-011-0996-z

Authier, M., Bentaleb, I., Ponchon, A., Martin, C., and Guinet, C. (2012). Foraging fidelity as a recipe for a long life: foraging strategy and longevity in male southern elephant seals. PLoS One 7:e32026. doi: 10.1371/journal.pone. 0032026

Avila, I. C., Dormann, C. F., García, C., Payán, L. F., and Zorrilla, M. X. (2020). Humpback whales extend their stay in a breeding ground in the Tropical Eastern Pacific. ICES J. Mar. Sci. 77, 109-118. doi: 10.1093/icesjms/fsz2

Bailleul, F., Cotté, C., and Guinet, C. (2010). Mesoscale eddies as foraging area of a deep-diving predator, the southern elephant seal. Mar. Ecol. Prog. Ser. 408, 251-264. doi: 10.3354/meps08560

Bakir, A., O’Connor, I. A., Rowland, S. J., Hendriks, A. J., and Thompson, R. C. (2016). Relative importance of microplastics as a pathway for the transfer of hydrophobic organic chemicals to marine life. Environ. Pollut. 219, 56-65. doi: 10.1016/j.envpol.2016.09.046

Ballerini, T., Tavecchia, G., Pezzo, F., Jenouvrier, S., and Olmastroni, S. (2015). Predicting responses of the Adélie penguin population of Edmonson Point to future sea ice changes in the Ross Sea. Front. Ecol. Evol. 3:8. doi: 10.3389/fevo. 2015.00008

Barber-Meyer, S. M., Kooyman, G. L., and Ponganis, P. J. (2008). Trends in western Ross Sea emperor penguin chick abundances and their relationships to climate. Antarct. Sci. 20, 3-11. doi: 10.1017/S0954102007000673

Barbosa, A., and Palacios, M. J. (2009). Health of Antarctic birds: a review of their parasites, pathogens and diseases. Polar Biol. 32, 1095-1115. doi: 10.1007/ s00300-009-0640-3

Barbraud, C., Rolland, V., Jenouvrier, S., Nevoux, M., Delord, K., and Weimerskirch, H. (2012). Effects of climate change and fisheries bycatch on Southern Ocean seabirds: a review. Mar. Ecol. Prog. Ser. 454, 285-307. doi: 10.3354/meps09616

Barbraud, C., and Weimerskirch, H. (2001a). Contrasting effects of the extent of sea-ice on the breeding performance of an Antarctic top predator, the snow petrel Pagodroma nivea. J. Avian Biol. 32, 297-302. doi: 10.1111/j.0908-8857. 2001.320402.x

Barbraud, C., and Weimerskirch, H. (2001b). Emperor penguins and climate change. Nature 411, 183-186. doi: 10.1038/35075554

Barbraud, C., and Weimerskirch, H. (2006). Antarctic birds breed later in response to climate change. Proc. Natl. Acad. Sci. U.S.A. 103, 6248-6251. doi: 10.1073/ pnas.0510397103

Basberg, B. L., and Headland, R. K. (2008). The 19th Century Antarctic Sealing Industry: Sources, Data and Economic Significance. NHH Department of Economics Discussion Paper No. 21/2008. Amsterdam: Elsevier. doi: 10.2129/ ssrn. 1553751

Beaulieu, M., Ropert-Coudert, Y., Le Maho, Y., Ancel, A., and Criscuolo, F. (2010). Foraging in an oxidative environment: relationship between $\delta 13 \mathrm{C}$ values and oxidative status in Adélie penguins. Proc. R. Soc. B Biol. Sci. 277, 1087-1092. doi: $10.1098 / \mathrm{rspb} .2009 .1881$

Bengtson, J. L., Boveng, P., Franzen, U., Have, P., Heide-Jørgensen, M. P., and Härkönen, T. J. (1991). Antibodies to canine distemper virus in Antarctic seals. Mar. Mamm. Sci. 7, 85-87. doi: 10.1111/j.1748-7692.1991.tb00553.x

Bengtson Nash, S. (2011). Persistent organic pollutants in Antarctica: current and future research priorities. J. Environ. Monitor. 13, 497-504. doi: 10.1039/ COEM00230E

Bengtson Nash, S., Poulsen, A. H., Kawaguchi, S., Vetter, W., and Schlabach, M. (2008). Persistent organohalogen contaminant burdens in Antarctic krill (Euphausia superba) from the eastern Antarctic sector: a baseline study. Sci. Total Environ. 407, 304-314. doi: 10.1016/j.scitotenv.2008.08.034

Bengtson Nash, S., Rintoul, S. R., Kawaguchi, S., Staniland, I., van den Hoff, J., Tierney, M., et al. (2010). Perfluorinated compounds in the Antarctic region: ocean circulation provides prolonged protection from distant sources. Environ. Pollut. 158, 2985-2991. doi: 10.1016/j.envpol.2010.05.024

Bengtson Nash, S. M. (2018). “Toxicological risks and considerations associated with lipophilic contaminant burdens of Southern Ocean mysticetes," in Marine Mammal Ecotoxicology: Impacts of Multiple Stressors on Population Health, 1st Edn, eds C. Fossi and C. Panti (London: Elsevier), 381-340.

Bengtson Nash, S. M., Castrillon, J., Eisenmann, P., Fry, B., Shuker, J. D., Cropp, R. A. et al. (2018). Signals from the south; humpback whales carry messages of Antarctic sea-ice ecosystem variability. Global Change Biol. 24, 1500-1510. doi: $10.1111 /$ gcb.14035

Bengtson Nash, S. M., Wild, S. J., Hawker, D. W., Cropp, R. A., Hung, H., Wania, F., et al. (2017). Persistent organic pollutants in the East Antarctic atmosphere: inter-annual observations from 2010 to 2015 using high-flow-through passive sampling. Environ. Sci. Technol. 51, 13929-13937. doi: 10.1021/acs.est.7b04224

Benoit, J. B., Lopez-Martinez, G., Elnitsky, M. A., Lee, R. E., and Denlinger, D. L. (2009). Increase in feeding by the tick, Ixodes uriae, on Adélie penguins during a prolonged summer. Antarct. Sci. 21, 151-152. doi: 10.1017/ S0954102008001685

Bestley, S., Andrews-Goff, V., van Wijk, E., Rintoul, S. R., Double, M. C., and How, J. (2019). New insights into prime Southern Ocean forage grounds for thriving Western Australian humpback whales. Sci. Rep. 9:13988. doi: 10.1038/s41598019-50497-2

Biuw, M., Nøst, O. A., Stien, A., Zhou, Q., Lydersen, C., and Kovacs, K. M. (2010). Effects of hydrographic variability on the spatial, seasonal and diel diving patterns of southern elephant seals in the Eastern Weddell Sea. PLoS One 5:e13816. doi: 10.1371/journal.pone.0013816 
Blevin, P., Carravieri, A., Jaeger, A., Chastel, O., Bustamante, P., and Cherel, Y. (2013). Wide range of mercury contamination in chicks of Southern Ocean seabirds. PLoS One 8:e54508. doi: 10.1371/journal.pone.0054508

Boonzaier, L., Harper, S., Zeller, D., and Pauly, D. (2012). "A brief history of fishing in the Prince Edward Islands, South Africa, 1950-2010," in Fisheries Catch Reconstructions: Islands, Part III, Fisheries Centre Research Reports No. 5, Vol. 20, eds S. Harper, K. Zylich, L. Boonzaier, F. Le Manach, D. Pauly, and D. Zeller (Vancouver: University of British Columbia), 95-101.

Bost, C. A., Cotté, C., Bailleul, F., Cherel, Y., Charrassin, J. B., Guinet, C., et al. (2009). The importance of oceanographic fronts to marine birds and mammals of the southern oceans. J. Mar. Syst. 78, 363-376. doi: 10.1016/j.jmarsys.2008. 11.022

Bost, C. A., Cotté, C., Terray, P., Barbraud, C., Bon, C., Delord, K., et al. (2015). Large-scale climatic anomalies affect marine predator foraging behaviour and demography. Nat. Commun. 6:8220. doi: 10.1038/ncomms 9220

Bost, C. A., Handrich, Y., Butler, P. J., Fahlman, A., Halsey, L. G., Woakes, A. J., et al. (2007). Changes in dive profiles as an indicator of feeding success in king and Adélie penguins. Deep Sea Res. II Top. Stud. Oceanogr. 54, 248-255. doi: 10.1016/j.dsr2.2006.11.007

Bradshaw, C. J., Hindell, M. A., Best, N. J., Phillips, K. L., Wilson, G., and Nichols, P. D. (2003). You are what you eat: describing the foraging ecology of southern elephant seals (Mirounga leonina) using blubber fatty acids. Proc. R. Soc. Lond. B Biol. Sci. 270, 1283-1292.

Bradshaw, C. J. A., Hindell, M. A., Sumner, M. D., and Michael, K. J. (2004). Loyalty pays: potential life history consequences of fidelity to marine foraging regions by southern elephant seals. Anim. Behav. 68, 1349-1360. doi: 10.1016/j.anbehav. 2003.12.013

Branch, T. A. (2011). Humpback whale abundance south of $60^{\circ} \mathrm{S}$ from three complete circumpolar sets of surveys. J. Cetacean Res. Manag. 3, 53-69.

Branch, T. A., Matsuoka, K., and Miyashita, T. (2004). Evidence for increases in Antarctic blue whales based on Bayesian modelling. Mar. Mamm. Sci. 20, 726-754. doi: 10.1111/j.1748-7692.2004.tb01190.x

Brault, E. K., Koch, P. L., Costa, D. P., McCarthy, M. D., Hückstädt, L. A., Goetz, K. T., et al. (2019). Trophic position and foraging ecology of Ross, Weddell, and crabeater seals revealed by compound-specific isotope analysis. Mar. Ecol. Prog. Ser. 611, 1-18. doi: 10.3354/meps12856

Brault, E. K., Koch, P. L., McMahon, K. W., Broach, K. H., Rosenfield, A. P., Sauthoff, W., et al. (2018). Carbon and nitrogen zooplankton isoscapes in West Antarctica reflect oceanographic transitions. Mar. Ecol. Prog. Ser. 593, 29-45. doi: 10.3354/meps12524

Brodier, S., Pisanu, B., Villers, A., Pettex, E., Lioret, M., Chapuis, J. L., et al. (2011). Responses of seabirds to the rabbit eradication on Ile Verte, sub-Antarctic Kerguelen Archipelago. Anim. Conserv. 14, 459-465. doi: 10.1111/j.1469-1795. 2011.00455.x

Brooks, C. M., Chown, S. L., Douglass, L., Raymond, B., Shaw, J., Sylvester, Z., et al. (2020). Progress towards a representative network of Southern Ocean protected areas. PLoS One 15:e0231361. doi: 10.1371/journal.pone.023 1361

Brooks, S. T., Jabour, J., van den Hoff, J., and Bergstrom, D. M. (2019). Our footprint on Antarctica competes with nature for rare ice-free land. Nat. Sustain. 2, 185-190. doi: 10.1038/s41893-019-0237-y

Burkard, M., Bengtson Nash, S., Gambaro, G., Whitworth, D., and Schirmer, K. (2019). Lifetime extension of humpback whale skin fibroblasts and their response to lipopolysaccharide (LPS) and a mixture of polychlorinated biphenyls (Aroclor). Cell Biol. Toxicol. 35, 387-398. doi: 10.1007/s10565-01809457-1

Burkard, M., Whitworth, D., Schirmer, K., and Bengtson Nash, S. (2015). Establishment of the first humpback whale fibroblast cell lines and their application in chemical risk assessment. Aquat. Toxicol. 167, 240-247. doi: 10.1016/j.aquatox.2015.08.005

Burton Jr, G. A., Di Giulio, R., Costello, D., and Rohr, J. R. (2017). Slipping through the cracks: why is the US Environmental Protection Agency not funding extramural research on chemicals in our environment? Environ. Sci. Technol. 51, 755-756. doi: 10.1021/acs.est.6b05877

Bustnes, J. O., Tveraa, T., Henden, J. A., Varpe, Ø., Janssen, K., and Skaare, J. U. (2006). Organochlorines in Antarctic and Arctic avian top predators: a comparison between the south polar skua and two species of northern hemisphere gulls. Environ. Sci. Technol. 40, 2826-2831.
Bustnes, J. O., Tveraa, T., Varpe, Ø., Henden, J. A., and Skaare, J. U. (2007). Reproductive performance and organochlorine pollutants in an Antarctic marine top predator: the south polar skua. Environ. Int. 33, 911-918.

Campagna, C., Piola, A. R., Marin, M. R., Lewis, M., and Fernández, T. (2006). Southern elephant seal trajectories, fronts and eddies in the Brazil/Malvinas Confluence. Deep Sea Res. I Oceanogr. Res. Pap. 53, 1907-1924. doi: 10.1016/ j.dsr.2006.08.015

Carey, M. J. (2009). The effects of investigator disturbance on procellariiform seabirds: a review. N. Z. J. Zool. 36, 367-377. doi: 10.1080/0301422090950161

Carpenter-Kling, T., Handley, J. M., Connan, M., Crawford, R. J. M., Makhado, A. B., Dyer, B. M., et al. (2019). Gentoo penguins as sentinels of climate change at the sub-Antarctic Prince Edward Archipelago, Southern Ocean. Ecol. Indic. 101, 163-172. doi: 10.1016/j.ecolind.2019.01.008

Carroll, E. L., Baker, C. S., Watson, M., Alderman, R., Bannister, J., Gaggiotti, O. E., et al. (2015). Migratory traditions shape the genetic structure of southern right whales around Australia and New Zealand. Sci. Rep. 5:16182. doi: 10.1038/ srep 16182

Cavalieri, D. J. C. L., and Parkinson. (2012). Antarctic sea ice variability and trends, 1979-2010. Cryosphere 6, 881-889. doi: 10.5194/tc-6-881-2012

CCAMLR (2001). CCAMLRs Management of the Antarctic 2001. Hobart: CCAMLR.

CCAMLR (2009a). Report of the Working Group on Incidental Mortality Associated with Fishing (IMAF). Hobart: CCAMLR.

CCAMLR (2009b). Resolution 30/XXVIII Climate Change. Hobart: CCAMLR.

CCAMLR (2009c). Resolution 31/XXVIII, Best Available Science. Hobart: CCAMLR.

CCAMLR (2010). Report of the Working Group on Fish Stock Assessment. Available online at: https://www.ccamlr.org/en/system/files/e-sc-xxix-a8.pdf (accessed October 22, 2010).

CCAMLR (2011). Report of the Working Group on Incidental Mortality Associated with Fishing (IMAF). Available online at: https://www.ccamlr.org/en/system/ files/e-sc-xxx-a08.pdf (accessed October 12, 2011).

CCAMLR (2012). Fishery Report Dissostichus eleginoides (TOP) South Georgia (Subarea 48.3). Available online at: https://www.ccamlr.org/en/document/ publications/fishery-report-dissostichus-eleginoides-top-south-georgiasubarea-48-3 (accessed April 5, 2013).

CCAMLR (2018a). Fishery Report 2018 Dissostichus eleginoides Heard Island Australian EZZ (Division 58.5.2). Available online at: https://www.ccamlr. org/en/document/publications/fishery-report-2018-dissostichus-eleginoidesheard-island-australian-eez (accessed April 5, 2019).

CCAMLR (2018b). Fishery Report 2018 Dissostichus eleginoides South Georgia (Subarea 48.3). Available online at: https://www.ccamlr.org/en/document/ publications/fishery-report-2018-dissostichus-eleginoides-south-georgiasubarea-48-3 (accessed April 3, 2019).

CCAMLR (2018c). Krill Fishery Report 2018. Available online at: https://www. ccamlr.org/en/publications/fishery-reports (accessed August 12, 2020).

CCAMLR (2019a). Scientific Committee Report 2019 SC-CAMLR-38. Available online at: https:/www.asoc.org/storage/documents/Meetings/CCAMLR/38/ asoc-paper-22-2019.pdf (accessed September 21, 2019).

CCAMLR (2019b). Summary of Incidental Mortality Associated with Fishing Activities Collected in Scientific Observer and Vessel Data During the 2019 Season. CCAMLR WG-FSA-2019/16 Rev. 2. Available online at: https://www. ccamlr.org/en/wg-fsa-2019/16-rev-2 (accessed November 26, 2019).

CCAMLR (2019c). Report of the Thirty-Eighth Meeting of the Commission. Available online at: https://www.ccamlr.org/en/ccamlr-38/32 (accessed October 28, 2019).

CEP (2019). Report of the Twenty-Second Meeting of the Committee for Environmental Protection (CEP XXII). Available online at: https://documents. ats.aq/ATCM42/cr/ATCM42_cr001_e.pdf (accessed July 5, 2019).

Chambers, L. E., Dann, P., Cannell, B., and Woehler, E. J. (2014). Climate as a driver of phenological change in southern seabirds. Int. J. Biometeorol. 58, 603-612. doi: 10.1007/s00484-013-0711-6

Chapman, C. C., Lea, M. A., Meyer, A., Sallée, J. B., and Hindell, M. (2020). Defining Southern Ocean fronts and their influence on biological and physical processes in a changing climate. Nat. Clim. Change 10, 209-219. doi: 10.1038/ s41558-020-0705-4

Chastel, C., Demazure, M., Chastel, O., Genevois, F., Legrand, M. C., Grulet, O., et al. (1993). A rickettsia-like organism from Ixodes uriae ticks collected 
on the Kerguelen Islands (French Subantarctic Territories). Acta Virol. 37, $11-20$.

Che-Castaldo, C., Jenouvrier, S., Youngflesh, C., Shoemaker, K. T., Humphries, G., McDowall, P., et al. (2017). Pan-Antarctic analysis aggregating spatial estimates of Adélie penguin abundance reveals robust dynamics despite stochastic noise. Nat. Commun. 8:832. doi: 10.1038/s41467-01700890-0

Cherel, Y., Barbraud, C., Lahournat, M., Jaeger, A., Jaquemet, S., Wanless, et al. (2018). Accumulate or eliminate? Seasonal mercury dynamics in albatrosses, the most contaminated family of birds. Environ. Pollut. 241, 124-135. doi: 10.1016/j.envpol.2018.05.048

Cherel, Y., Weimerskirch, H., and Trouvé, C. (2000). Food and feeding ecology of the neritic-slope forager black-browed albatross and its relationships with commercial fisheries in Kerguelen waters. Mar. Ecol. Prog. Ser. 207, 183-199. doi: 10.3354/meps207183

Cherel, Y., Xavier, J. C., de Grissac, S., Trouvé, C., and Weimerskirch, H. (2017). Feeding ecology, isotopic niche, and ingestion of fishery-related items of the wandering albatross Diomedea exulans at Kerguelen and Crozet Islands. Mar. Ecol. Prog. Ser. 565, 197-215. doi: 10.3354/meps11994

Chidichimo, M. P., Donohue, K. A., Watts, D. R., and Tracey, K. L. (2014). Baroclinic transport time series of the Antarctic Circumpolar Current measured in Drake Passage. J. Phys. Oceanogr. 44, 1829-1853. doi: 10.1175/JPO-D-13071.1

Chown, S. L., and Brooks, C. M. (2019). The state and future of Antarctic environments in a global context. Annu. Rev. Environ. Resour. 44, 1-30. doi: 10.1146/annurev-environ-101718-033236

Christiansen, F., Bertulli, C. G., Rasmussen, M. H., and Lusseau, D. (2015). Estimating cumulative exposure of wildlife to non-lethal disturbance using spatially explicit capture-recapture models. J. Wildl. Manag. 79, 311-324. doi: 10.1002/jwmg.836

Christiansen, F., and Lusseau, D. (2015). Linking behavior to vital rates to measure the effects of non-lethal disturbance on wildlife. Conserv. Lett. 8, 424-431. doi: $10.1111 /$ conl.12166

Christiansen, H., Dettai, A., Heindler, F. M., Collins, M. A., Duhamel, G., Hautecoeur, M., et al. (2018). Diversity of mesopelagic fishes in the Southern Ocean 3/4 a phylogeographic perspective using DNA barcoding. Front. Ecol. Evol. 6:120. doi: 10.3389/fevo.2018.00120

Cipro, C. V. Z., Bustamante, P., Petry, M. V., and Montone, R. C. (2018). Seabird colonies as relevant sources of pollutants in Antarctic ecosystems: part 1-Trace elements. Chemosphere 204, 535-547. doi: 10.1016/j.chemosphere.2018.02.048

Clarke, A., and Tyler, P. A. (2008). Adult Antarctic krill feeding at abyssal depths. Curr. Biol. 18, 282-285. doi: 10.1016/j.cub.2008.01.059

Clay, T. A., Small, C., Tuck, G. N., Pardo, D., Carneiro, A. P., Wood, A. G., et al. (2019). A comprehensive large-scale assessment of fisheries bycatch risk to threatened seabird populations. J. Appl. Ecol. 56, 1882-1893. doi: 10.1111/ 1365-2664.13407

Clucas, G. V., Younger, J. L., Kao, D., Emmerson, L., Southwell, C., Wienecke, B., et al. (2018). Comparative population genomics reveals key barriers to dispersal in Southern Ocean penguins. Mol. Ecol. 27, 4680-4697. doi: 10.1111/mec.14896

Coetzee, B. W., and Chown, S. L. (2016). A meta-analysis of human disturbance impacts on Antarctic wildlife. Biol. Rev. 91, 578-596. doi: 10.1111/brv.12184

Coffin, S., Huang, G. Y., Lee, I., and Schlenk, D. (2019). Fish and seabird gut conditions enhance desorption of estrogenic chemicals from commonlyingested plastic items. Environ. Sci. Technol. 53, 4588-4599. doi: 10.1021/acs. est.8b07140

Cole, T. L., Dutoit, L., Dussex, N., Hart, T., Alexander, A., Younger, J. L., et al. (2019). Receding ice drove parallel expansions in Southern Ocean penguins. Proc. Natl. Acad. Sci. U.S.A. 116, 26690-26696. doi: 10.1073/pnas. 1904048116

Connan, M., Dilley, B. J., Whitehead, T. O., Davies, D., McQuaid, C. D., and Ryan, P. G. (2019). Multidimensional stable isotope analysis illuminates resource partitioning in a sub-Antarctic island bird community. Ecography 42, 19481959. doi: $10.1111 /$ ecog. 04560

Connan, M., McQuaid, C. D., Bonnevie, B. T., Smale, M. J., and Cherel, Y. (2014). Combined stomach content, lipid and stable isotope analyses reveal spatial and trophic partitioning among three sympatric albatrosses from the Southern Ocean. Mar. Ecol. Prog. Ser. 497, 259-272. doi: 10.3354/meps 10606

Constable, A. J., Melbourne-Thomas, J., Corney, S. P., Arrigo, K. R., Barbraud, C., Barnes, D. K., et al. (2014). Climate change and Southern Ocean ecosystems I: how changes in physical habitats directly affect marine biota. Glob. Change Biol. 20, 3004-3025. doi: 10.1111/gcb.12623

Constantine, R., Jackson, J. A., Steel, D., Baker, C. S., Brooks, L., Burns, D., et al. (2012). Abundance of humpback whales in Oceania using photo-identification and microsatellite genotyping. Mar. Ecol. Prog. Ser. 453, 249-261. doi: 10.3354/ meps09613

Convey, P. (2011). Antarctic terrestrial biodiversity in a changing world. Polar Biol. 34:1629. doi: 10.1007/s00300-011-1068-0

Convey, P., and Peck, L. S. (2019). Antarctic environmental change and biological responses. Sci. Adv. 5:eaaz0888. doi: 10.1126/sciadv.aaz0888

Corsolini, S., Ademollo, N., Romeo, T., Olmastroni, S., and Focardi, S. (2003). Persistent organic pollutants in some species of a Ross Sea pelagic trophic web. Antarct. Sci. 15, 95-104.

Cossa, D., Heimbürger, L. E., Lannuzel, D., Rintoul, S. R., Butler, E. C., Bowie, A. R., et al. (2011). Mercury in the Southern Ocean. Geochim. Cosmochim. Acta 75, 4037-4052. doi: 10.1016/j.gca.2011.05.001

Costa, D. P., Huckstadt, L. A., Crocker, D. E., McDonald, B. I., Goebel, M. E., and Fedak, M. A. (2010). Approaches to studying climatic change and its role on the habitat selection of Antarctic pinnipeds. Integr. Comp. Biol. 50, 1018-1030. doi: $10.1093 /$ icb/icq054

Cotté, C., d’Ovidio, F., Dragon, A. C., Guinet, C., and Lévy, M. (2015). Flexible preference of southern elephant seals for distinct mesoscale features within the Antarctic Circumpolar Current. Prog. Oceanogr. 131, 46-58. doi: 10.1016/j. pocean.2014.11.011

Cotté, C., Park, Y. H., Guinet, C., and Bost, C. A. (2007). Movements of foraging king penguins through marine mesoscale eddies. Proc. R. Soc. B Biol. Sci. 274, 2385-2391. doi: 10.1098/rspb.2007.0775

Crawford, R. J. M., and Cooper, J. (2003). Conserving surface-nesting seabirds at the Prince Edward Islands: the roles of research, monitoring and legislation. Afr. J. Mar. Sci. 25, 415-426. doi: 10.2989/18142320309504031

Crespo, E. A., Pedraza, S. N., Dans, S. L., Alonso, M. K., Reyes, L. M., García, N. A., et al. (1997). Direct and indirect effects of the highseas fisheries on the marine mammal populations in the northern and central Patagonian coast. J. Northwest Atl. Fish. Sci. 22, 189-207.

Cristofari, R., Liu, X., Bonadonna, F., Cherel, Y., Pistorius, P., Le Maho, Y., et al. (2018). Climate-driven range shifts of the king penguin in a fragmented ecosystem. Nat. Clim. Change 8, 245-251. doi: 10.1038/s41558-0180084-2

Crossin, G. T., Trathan, P. N., and Crawford, R. J. M. (2013). "Macaroni penguin (Eudyptes chrysolophus) Royal penguin (Eudyptes schlegeli)," in Penguins: Natural History and Conservation, eds P. G. Borboroglu and P. D. Boersma (Seattle, WA: University of Washington Press), 185-208.

Croxall, J. P., and Nicol, S. (2004). Management of Southern Ocean fisheries: global forces and future sustainability. Antarct. Sci. 16, 569-584. doi: 10.1017/ S0954102004002330

Das, K., Malarvannan, G., Dirtu, A., Dulau, V., Dumont, M., Lepoint, G., et al. (2017). Linking pollutant exposure of humpback whales breeding in the Indian Ocean to their feeding habits and feeding areas off Antarctica. Environ. Pollut. 220, 1090-1099. doi: 10.1016/j.envpol.2016.11.032

De Broyer, C., Koubbi, P., Griffiths, H., Raymond, B., d'Udekem d'Acoz, C., van de Putte, A., et al. (2014). Biogeographic Atlas of the Southern Ocean. Cambridge: Scientific Committee on Antarctic Research.

de Morais, I. O. B., Danilewicz, D., Zerbini, A. N., Edmundson, W., Hart, I. B., and Bortolotto, G. A. (2016). From the southern right whale hunting decline to the humpback whaling expansion: a review of whale catch records in the tropical western South Atlantic Ocean. Mammal Rev. 47, 11-23. doi: 10.1111/ mam.12073

de Villiers, M., Bause, M., Giese, M., and Fourie, A. (2006). Hardly hard-hearted: heart rate responses of incubating northern giant petrels (Macronectes halli) to human disturbance on sub-Antarctic Marion Island. Polar Biol. 29, 717-720. doi: 10.1007/s00300-006-0137-2

de Villiers, M. S., Cooper, J., and Ryan, P. G. (2005). Individual variability of behavioural responses by wandering albatrosses (Diomedea exulans) to human disturbance. Polar Biol. 28, 255-260. doi: 10.1007/s00300-004-0682-5

Dehnhard, N., Poisbleau, M., Demongin, L., Ludynia, K., Lecoq, M., Masello, J. F., et al. (2013). Survival of rockhopper penguins in times of global climate change. Aquat. Conserv. 23, 777-789. doi: 10.1002/aqc.2331 
Della Penna, A., De Monte, S., Kestenare, E., Guinet, C., and d'Ovidio, F. (2015). Quasi-planktonic behavior of foraging top marine predators. Sci. Rep. 5:18063. doi: $10.1038 /$ srep 18063

Delord, K., Barbraud, C., Bost, C.-A., Deceuninck, B., Lefebvre, T., Lutz, R., et al. (2014). Areas of importance for seabirds tracked from French southern territories, and recommendations for conservation. Mar. Policy 48, 1-13. doi: 10.1016/j.marpol.2014.02.019

Delord, K., Cotté, C., Péron, C., Marteau, C., Pruvost, P., Gasco, N., et al. (2010). Atsea distribution and diet of an endangered top predator: relationship between white-chinned petrels and commercial longline fisheries. Endanger. Species Res. 13, 1-16. doi: 10.3354/esr00309

Delord, K., Gasco, N., Weimerskirch, H., Barbraud, C., and Micol, T. (2005). Seabird mortality in the Patagonian toothfish longline fishery around Crozet and Kerguelen Islands, 2001-2003. CCAMLR Sci. 12, 53-80.

Delord, K., Kato, A., Tarroux, A., Orgeret, F., Cotté, C., Ropert-Coudert, Y., et al. (2020). Antarctic petrels 'on the ice rocks': wintering strategy of an Antarctic seabird. R. Soc. Open Sci. 7:191429. doi: 10.1098/rsos.191429

Delord, K., Roudaut, G., Guinet, C., Barbraud, C., Bertrand, S., and Weimerskirch, H. (2015). Kite aerial photography: a low-cost method for monitoring seabird colonies. J. Field Ornithol. 86, 173-179. doi: 10.1111/jofo.12100

Descamps, S., Tarroux, A., Cherel, Y., Delord, K., Godø, O. R., Kato, A., et al. (2016). At-sea distribution and prey selection of Antarctic petrels and commercial krill fisheries. PLoS One 11:e0156968. doi: 10.1371/journal.pone. 0156968

Descamps, S., Tarroux, A., Varpe, Ø., Yoccoz, N. G., Tveraa, T., and Lorentsen, S. H. (2015). Demographic effects of extreme weather events: snow storms, breeding success, and population growth rate in a long-lived Antarctic seabird. Ecol. Evol. 5, 314-325. doi: 10.1002/ece3.1357

Dhabhar, F. S. (2009). Enhancing versus suppressive effects of stress on immune function: implications for immunoprotection and immunopathology. Neuroimmunomodulation 16, 300-317. doi: 10.1159/000216188

Dilley, B. J., Schoombie, S., Schoombie, J., and Ryan, P. G. (2016). 'Scalping' of albatross fledglings by introduced mice spreads rapidly at Marion Island. Antarct. Sci. 28, 73-80.

Dorneles, P. R., Lailson-Brito, J., Secchi, E. R., Dirtu, A. C., Weijs, L., Dalla Rosa, L., et al. (2015). Levels and profiles of chlorinated and brominated contaminants in Southern Hemisphere humpback whales, Megaptera novaeangliae. Environ. Res. 138, 49-57. doi: 10.1016/j.envres.2015.02.007

d'Ovidio, F., De Monte, S., Della Penna, A., Cotté, C., and Guinet, C. (2013). Ecological implications of eddy retention in the open ocean: a Lagrangian approach. J. Phys. A Math. Theor. 46:254023. doi: 10.1088/1751-8113/46/25/ 254023

Dragon, A. C., Monestiez, P., Bar-Hen, A., and Guinet, C. (2010). Linking foraging behaviour to physical oceanographic structures: southern elephant seals and mesoscale eddies east of Kerguelen Islands. Prog. Oceanogr. 87, 61-71. doi: 10.1016/j.pocean.2010.09.025

Ducklow, H. W., Baker, K., Martinson, D. G., Quetin, L. B., Ross, R. M., Smith, R. C., et al. (2007). Marine pelagic ecosystems: the west Antarctic Peninsula. Philos. Trans. R. Soc. B Biol. Sci. 362, 67-94. doi: 10.1098/rstb.2006.1955

Dunn, M. J., Forcada, J., Jackson, J. A., Waluda, C. M., Nichol, C., and Trathan, P. N. (2019). A long-term study of gentoo penguin (Pygoscelis papua) population trends at a major Antarctic tourist site, Goudier Island, Port Lockroy. Biodivers. Conserv. 28, 37-53. doi: 10.1007/s10531-018-1635-6

Egevang, C., Stenhouse, I. J., Phillips, R. A., Petersen, A., Fox, J. W., and Silk, J. R. (2010). Tracking of Arctic terns Sterna paradisaea reveals longest animal migration. Proc. Natl. Acad. Sci. U.S.A. 107, 2078-2081. doi: 10.1073/pnas. 0909493107

Ellenberg, U. (2017). "Impacts of P\penguin tourism," in Ecotourism's Promise and Peril: A Biological Evaluation, eds D. T. Blumstein, B. Geffroy, D. S. M. Samia, and E. Bessa (Cham: Springer International Publishing), 117-132. doi: 10.1007/978-3-319-58331-0_8

Engelhard, G., Brasseur, S. M. J. M., Hall, A., Burton, H., and Reijnders, P. (2002). Adrenocortical responsiveness in southern elephant seal mothers and pups during lactation and the effect of scientific handling. J. Comp. Phys. B 172, 315-328. doi: 10.1007/s00360-002-0257-0

Engelhard, G. H., van den Hoff, J., Broekman, M., Baarspul, A. N., Field, I., Burton, H. R., et al. (2001). Mass of weaned elephant seal pups in areas of low and high human presence. Polar Biol. 24, 244-251. doi: 10.1007/s003000000204
Environmental Protocol (1991). The Protocol on Environmental Protection to the Antarctic Treaty. Available online at: https://www.ats.aq/e/protocol.html\#: $\sim\{\}:$ text=The\%20Protocol\%20on\%20Environmental\%20Protection $\% 20$ to $\%$ 20the $\% 20$ Antarctic $\% 20$ Treaty\%20was, peace $\% 20$ and $\% 20$ science $\%$ E2\%80\% 9D\%20(Art.\&text=Annexes\%20I\%20to\%20IV\%20were, entered\%20into\% 20force\%20in\%201998 (accessed March 13, 2020).

Erbe, C., Dähne, M., Gordon, J., Herata, H., Houser, D. S., Koschinski, S., et al. (2019). Managing the effects of noise from ship traffic, seismic surveying and construction on marine mammals in Antarctica. Front. Mar. Sci. 6:647. doi: $10.3389 /$ fmars.2019.00647

FAO (2011). Review of the State of World Marine Fishery Resources. FAO Fisheries and Aquaculture Technical Paper No. 569. Rome: FAO.

Fedak, M. A. (2013). The impact of animal platforms on polar ocean observation. Deep Sea Res. II Top. Stud. Oceanogr. 88, 7-13. doi: 10.1016/j.dsr2.2012. 07.007

Flores, H., Atkinson, A., Kawaguchi, S., Krafft, B. A., Milinevsky, G., Nicol, S., et al. (2012). Impact of climate change on Antarctic krill. Mar. Ecol. Prog. Ser. 458, 1-19. doi: 10.3354/meps09831

Forcada, J., and Hoffman, J. I. (2014). Climate change selects for heterozygosity in a declining fur seal population. Nature 511, 462-465. doi: 10.1038/nature13542

Forcada, J., and Trathan, P. N. (2009). Penguin responses to climate change in the Southern Ocean. Glob. Change Biol. 15, 1618-1630. doi: 10.1111/j.1365-2486. 2009.01909.x

Forcada, J., Trathan, P. N., Boveng, P. L., Boyd, I. L., Burns, J. M., Costa, D. P., et al. (2012). Responses of Antarctic pack-ice seals to environmental change and increasing krill fishing. Biol. Conserv. 149, 40-50. doi: 10.1016/j.biocon.2012.02. 002

Fossi, M. C., and Panti, C. (2018). Marine Mammal Ecotoxicology Impacts of Multiple Stressors on Population Health. Amsterdam: Elsevier, 512.

Fossi, M. C., Panti, C., Guerranti, C., Coppola, D., Giannetti, M., Marsili, L., et al. (2012). Are baleen whales exposed to the threat of microplastics? A case study of the Mediterranean fin whale (Balaenoptera physalus). Mar. Pollut. Bull. 64, 2374-2379. doi: 10.1016/j.marpolbul.2012.08.013

Fraser, W. R., and Hofmann, E. E. (2003). A predator's perspective on causal links between climate change, physical forcing and ecosystem response. Mar. Ecol. Prog. Ser. 265, 1-15. doi: 10.3354/meps265001

Frenot, Y., Chown, S. L., Whinam, J., Selkirk, P. M., Convey, P., Skotnicki, M., et al. (2005). Biological invasions in the Antarctic: extent, impacts and implications. Biol. Rev. 80, 45-72. doi: 10.1017/S1464793104006542

Fretwell, P. T., and Trathan, P. N. (2019). Emperors on thin ice: three years of breeding failure at Halley Bay. Antarct. Sci. 31, 133-138. doi: 10.1017/ S0954102019000099

Friedheim, R. L. (2001). Towards a Sustainable Whaling Regime. Seattle, WA: University of Washington Press.

Friedlaender, A. S., Goldbogen, J. A., Nowacek, D. P., Read, A. J., Johnston, D., and Gales, N. (2014). Feeding rates and under-ice foraging strategies of the smallest lunge filter feeder, the Antarctic minke whale (Balaenoptera bonaerensis). J. Exp. Biol. 217, 2851-2854. doi: 10.1242/jeb.106682

Friedlaender, A. S., Halpin, P. N., Qian, S. S., Lawson, G. L., Wiebe, P. H., Thiele, D., et al. (2006). Whale distribution in relation to prey abundance and oceanographic processes in shelf waters of the Western Antarctic Peninsula. Mar. Ecol. Prog. Ser. 317, 297-310. doi: 10.3354/meps317297

Gall, S. C., and Thompson, R. C. (2015). The impact of debris on marine life. Mar. Pollut. Bull. 92, 170-179. doi: 10.1016/j.marpolbul.2014.12.041

Gamble, A., Garnier, R., Jaeger, A., Gantelet, H., Thibault, E., Tortosa, P., et al. (2019). Exposure of breeding albatrosses to the agent of avian cholera: dynamics of antibody levels and ecological implications. Oecologia 189, 939-949. doi: 10.1007/s00442-019-04369-1

García-Godos, I., Van Waerebeek, K., Alfaro-Shigueto, J., and Mangel, J. C. (2013). Entanglements of large cetaceans in Peru: few records but high risk. Pac. Sci. 67, 523-532. doi: 10.2984/67.4.3

Gasco, N., Tixier, P., Duhamel, G., and Guinet, C. (2015). Comparison of two methods to assess fish losses due to depredation by killer whales and sperm whales on demersal longline. CCAMLR Sci. 22, 1-14.

Gasco, N., Tixier, P., Massiot-Granier, F., Péron, C., and Sarralde, C. (2019a). No Boundaries for Whales Interacting with Fishing Activities Targeting Patagonian Toothfish (Dissostichus eleginoides) CCAMLR WG-FSA-2019/54. Available online at: https://www.ccamlr.org/en/wg-fsa-2019 (accessed October 18, 2019). 
Gasco, N., Tixier, P., Okuda, G., Péron, C., and Massiot-Granier, F. (2019b). Update Report on Marine Mammal Interactions in Division 58.4.4. CCAMLR WGSAM-2019/01. Available online at: https://www.ccamlr.org/en/wg-sam-2019/ 01 (accessed June 17, 2019).

Gelatt, T. S., Davis, C. S., Stirling, I., Siniff, D. B., Strobeck, C., and Delisle, I. (2010). History and fate of a small isolated population of Weddell seals at White Island, Antarctica. Conserv. Genet. 11, 721-735. doi: 10.1007/S10592-009-9856-6

George, J. L., and Frear, D. E. H. (1966). Pesticides in Antarctica. J. Appl. Ecol. 3, 155-167.

Germanov, E. S., Marshall, A. D., Bejder, L., Fossi, M. C., and Loneragan, N. R. (2018). Microplastics: no small problem for filter-feeding megafauna. Trends Ecol. Evol. 33, 227-232. doi: 10.1016/j.tree.2018.01.005

Giese, M. (1996). Effects of human activity on Adélie penguin Pygoscelis adeliae breeding success. Biol. Conserv. 75, 157-164. doi: 10.1016/0006-3207(95) 00060-7

Gille, S. T., and Meredith, M. P. (2017). “The Southern Ocean," in Satellite Altimetry over Oceans and Land Surfaces, eds D. Stammer and A. Cazenave (Boca Raton, FL: CRC Press), 297-314.

Goebel, M. E., Perryman, W. L., Hinke, J. T., Krause, D. J., Hann, N. A., Gardner, S., et al. (2015). A small unmanned aerial system for estimating abundance and size of Antarctic predators. Polar Biol. 38, 619-630. doi: 10.1007/s00300-0141625-4

Gonçalves, B. C., Spitzbart, B., and Lynch, H. J. (2020). SealNet: a fully-automated pack-ice seal detection pipeline for sub-meter satellite imagery. Remote Sens. Environ. 239:111617. doi: 10.1016/j.rse.2019.111617

Grachev, M. A., Kumarev, V. P., Mamaev, L. V., Zorin, V. L., Baranova, L. V., Denikina, N. N., et al. (1989). Distemper virus in Baikal seals. Nature 338, 209-209.

Gray, P. C., Bierlich, K. C., Mantell, S. A., Friedlaender, A. S., Goldbogen, J. A., and Johnston, D. W. (2019). Drones and convolutional neural networks facilitate automated and accurate cetacean species identification and photogrammetry. Methods Ecol. Evol. 10, 1490-1500. doi: 10.1111/2041-210X.13246

Grecian, W. J., Taylor, G. A., Loh, G., McGill, R. A., Miskelly, C. M., Phillips, R. A., et al. (2016). Contrasting migratory responses of two closely related seabirds to long-term climate change. Mar. Ecol. Prog. Ser. 559, 231-242. doi: 10.3354/meps11875

Grémillet, D., and Boulinier, T. (2009). Spatial ecology and conservation of seabirds facing global climate change: a review. Mar. Ecol. Prog. Ser. 391, 121-137. doi: $10.3354 /$ meps08212

Grémillet, D. J., and Plös, A. L. (1994). The use of stomach temperature records for the calculation of daily food intake in cormorants. J. Exp. Biol. 189, 105-115.

Grimaldi, W. W., Seddon, P. J., Lyver, P. O. B., Nakagawa, S., and Tompkins, D. M. (2015). Infectious diseases of Antarctic penguins: current status and future threats. Polar Biol. 38, 591-606. doi: 10.1007/s00300-014-1632-5

Guinet, C., Tixier, P., Gasco, N., and Duhamel, G. (2015). Long-term studies of Crozet Island killer whales are fundamental to understanding the economic and demographic consequences of their depredation behaviour on the Patagonian toothfish fishery. ICES J. Mar. Sci. 72, 1587-1597. doi: 10.1093/icesjms/fsu221

Hale, R. C., Kim, S. L., Harvey, E., La Guardia, M. J., Mainor, T. M., Bush, E. O., et al. (2008). Antarctic research bases: local sources of polybrominated diphenyl ether (PBDE) flame retardants. Environ. Sci. Technol. 42, 1452-1457. doi: 10.1021/es702547a

Harcourt, R., Sequeira, A. M. M., Zhang, X., Roquet, F., Komatsu, K., Heupel, M., et al. (2019). Animal-borne telemetry: an integral component of the ocean observing toolkit. Front. Mar. Sci. 6:326. doi: 10.3389/fmars.2019.00326

Harris, C. M., Herata, H., and Hertel, F. (2019). Environmental guidelines for operation of Remotely Piloted Aircraft Systems (RPAS): experience from Antarctica. Biol. Conserv. 236, 521-531. doi: 10.1016/j.biocon.2019.05.019

Hausmann, U., McGillicuddy, D. J. Jr., and Marshall, J. (2017). Observed mesoscale eddy signatures in Southern Ocean surface mixed-layer depth. J. Geophys. Res. Oceans 122, 617-635. doi: 10.1002/2016JC012225

Hazen, E. L., Abrahms, B., Brodie, S., Carroll, G., Jacox, M. G., Savoca, M. S., et al. (2019). Marine top predators as climate and ecosystem sentinels. Front. Ecol. Environ. 17, 565-574. doi: 10.1002/fee.2125

Heerah, K., Cox, S. L., Blevin, P., Guinet, C., and Charrassin, J. B. (2019). Validation of dive foraging indices using archived and transmitted acceleration data: the case of the Weddell seal. Front. Ecol. Evol. 7:30. doi: 10.3389/fevo.2019.00030
Hidalgo, M., and Browman, H. I. (2019). Developing the knowledge base needed to sustainably manage mesopelagic resources. ICES J. Mar. Sci. 76, 609-615. doi: 10.1093/icesjms/fsz067

Hindell, M. A., McMahon, C. R., Bester, M. N., Boehme, L., Costa, D., Fedak, M. A., et al. (2016). Circumpolar habitat use in the southern elephant seal: implications for foraging success and population trajectories. Ecosphere 7:e01213. doi: 10. $1002 /$ ecs 2.1213

Hindell, M. A., Reisinger, R. R., Ropert-Coudert, Y., Hückstädt, L. A., Trathan, P. N., Bornemann, H., et al. (2020). Tracking of marine predators to protect Southern Ocean ecosystems. Nature 580, 87-92. doi: 10.1038/s41586-0202126-y

Hindell, M. A., Sumner, M., Bestley, S., Wotherspoon, S., Harcourt, R. G., Lea, M. A., et al. (2017). Decadal changes in habitat characteristics influence population trajectories of southern elephant seals. Glob. Change Biol. 23, 51365150. doi: $10.1111 / \mathrm{gcb} .13776$

Hinke, J. T., Cossio, A. M., Goebel, M. E., Reiss, C. S., Trivelpiece, W. Z., and Watters, G. M. (2017). Identifying risk: concurrent overlap of the Antarctic krill fishery with krill-dependent predators in the Scotia Sea. PLoS One 12:e170132. doi: 10.1371/journal.pone.0170132

Hobbs, W. R., Massom, R., Stammerjohn, S., Reid, P., Williams, G., and Meier, W. (2016). A review of recent changes in Southern Ocean sea ice, their drivers and forcings. Glob. Planet. Change 143, 228-250. doi: 10.1016/j.gloplacha.2016.06. 008

Hoffman, J. I., Grant, S. M., Forcada, J., and Phillips, C. D. (2011). Bayesian inference of a historical bottleneck in a heavily exploited marine mammal. Mol. Ecol. 20, 3989-4008. doi: 10.1111/J.1365-294x.2011.05248.X

Hofman, R. (2017). Sealing, whaling and krill fishing in the Southern Ocean: past and possible future effects on catch regulations. Polar Rec. 53, 88-99. doi: $10.1017 /$ S0032247416000644

Holdaway, R. N., Thorneycroft, J. M., McClelland, P., and Bunce, M. (2010). Former presence of a parakeet (Cyanoramphus sp.) on Campbell Island, New Zealand subantarctic, with notes on the island's fossil sites and fossil record. Notornis 57, 8-18.

Hooper, J., Clark, J. M., Charman, C., and Agnew, D. (2005). Seal mitigation measures on trawl vessels fishing for krill in CCAMLR Subarea 48.3. CCAMLR Sci. 12, 195-205.

Hucke-Gaete, R., Moreno, C. A., Arata, J., and Ctr, B. W. (2004). Operational interactions of sperm whales and killer whales with the Patagonian toothfish industrial fishery off southern Chile. CCAMLR Sci. 11, 127-140.

Hückstädt, L. A., McCarthy, M. D., Koch, P. L., and Costa, D. P. (2017). What difference does a century make? Shifts in the ecosystem structure of the Ross Sea, Antarctica, as evidenced from a sentinel species, the Weddell seal. Proc. $R$. Soc. B Biol. Sci. 284:20170927. doi: 10.1098/rspb.2017.0927

Hughes, K. A., Constable, A., Frenot, Y., López-Martínez, J., McIvor, E., Njåstad, B., et al. (2018). Antarctic environmental protection: strengthening the links between science and governance. Environ. Sci. Policy 83, 86-95. doi: 10.1016/j. envsci.2018.02.006

Hughes, K. A., Fretwell, P., Rae, J., Holmes, K., and Fleming, A. (2011). Untouched Antarctica: mapping a finite and diminishing environmental resource. Antarct. Sci. 23, 537-548. doi: 10.1017/S095410201100037X

Hughes, K. A., and Grant, S. M. (2017). The spatial distribution of Antarctica's protected areas: a product of pragmatism, geopolitics or conservation need? Environ. Sci. Policy 72, 41-51.

Humphries, G. R. W., Naveen, R., Schwaller, M., Che-Castaldo, C., McDowall, P., Schrimpf, M., et al. (2017). Mapping application for penguin populations and projected dynamics (MAPPPD): data and tools for dynamic management and decision support. Polar Rec. 53, 160-166. doi: 10.1017/S0032247417000055

Hunt, G. L. Jr., Drinkwater, K. F., Arrigo, K., Berge, J., Daly, K. L., Danielson, S., et al. (2016). Advection in polar and sub-polar environments: impacts on high latitude marine ecosystems. Prog. Oceanogr. 149, 40-81. doi: 10.1016/j.pocean. 2016.10.004

Hurt, A. C., Su, Y. C., Aban, M., Peck, H., Lau, H., Baas, C., et al. (2016). Evidence for the introduction, reassortment, and persistence of diverse influenza A viruses in Antarctica. J. Virol. 90, 9674-9682. doi: 10.1128/JVI.01404-16

Hurt, A. C., Vijaykrishna, D., Butler, J., Baas, C., Maurer-Stroh, S., Silva-de-laFuente, M. C., et al. (2014). Detection of evolutionarily distinct avian influenza A viruses in Antarctica. mBio 5:e1098-14. doi: 10.1128/mBio.01098-14 
IAATO (2015). IAATO Policies on the Use of Unmanned Aerial Vehicles (UAVs) in Antarctica. Available online at: https://iaato.org/download/ip088-iaatopolicies-on-the-use-of-unmanned-aerial-vehicles-uavs-in-antarctica/ (accessed October 15, 2020).

IAATO (2019). Tourism Statistics. Available online at: https://iaato.org/tourismstatistics (accessed January 20, 2020).

IPCC (2019). In IPCC Special Report on the Ocean and Cryosphere in a Changing Climate, eds H.-O. Pörtner, D. C. Roberts, V. Masson-Delmotte, P. Zhai, M. Tignor, E. Poloczanska, et al. (Geneva: IPCC).

Iverson, S. J., Field, C., Don Bowen, W., and Blanchard, W. (2004). Quantitative fatty acid signature analysis: a new method of estimating predator diets. Ecol. Monogr. 74, 211-235. doi: 10.1890/02-4105

IWC (2013a). Annex G: report of the sub-committee on in-depth assessments. J. Cetacean Res. Manag. 14(Suppl.), 195-213.

IWC (2013b). Report of the IWC workshop on the assessment of Southern Right Whales. J. Cetacean Res. Manag. 14(Suppl.), 439-462.

IWC (2017). Report of the scientific committee. J. Cetacean Res. Manag. 18(Suppl.), $1-109$.

IWC (2018). Report of the scientific committee. Annex L. Report of the working group on ecosystem modelling. Appendix 5. Revised plans for the joint SC-CAMLR and IWC-SC Workshop 2018-2019. J. Cetacean Res. Manag. 19(Suppl.):302.

Jabour, J. (2009). "National Antarctic programs and their impact on the environment," in Health of Antarctic Wildlife: a Challenge for Science and Policy, eds K. R. Kerry and M. Riddle (Berlin: Springer), 211-230.

Jaeger, A., Lecomte, V. J., Weimerskirch, H., Richard, P., and Cherel, Y. (2010). Seabird satellite tracking validates the use of latitudinal isoscapes to depict predators' foraging areas in the Southern Ocean. Rapid Commun. Mass Spectrom. 24, 3456-3460. doi: 10.1002/rcm.4792

Janc, A., Richard, G., Guinet, C., Arnould, J. P., Villanueva, M. C., Duhamel, G., et al. (2018). How do fishing practices influence sperm whale (Physeter macrocephalus) depredation on demersal longline fisheries? Fish. Res. 206, 14-26. doi: 10.1016/j.fishres.2018.04.019

Jenouvrier, S., Barbraud, C., and Weimerskirch, H. (2003). Effects of climate variability on the temporal population dynamics of southern fulmars. J. Anim. Ecol. 72, 576-587. doi: 10.1046/j.1365-2656.2003.00727.x

Jenouvrier, S., Barbraud, C., and Weimerskirch, H. (2005). Long-term contrasted responses to climate of two Antarctic seabird species. Ecology 86, 2889-2903. doi: 10.1890/05-0514

Jenouvrier, S., Desprez, M., Fay, R., Barbraud, C., Weimerskirch, H., Delord, K., et al. (2018). Climate change and functional traits affect population dynamics of a long-lived seabird. J. Anim. Ecol. 87, 906-920. doi: 10.1111/1365-2556.12827

Jenouvrier, S., Garnier, J., Patout, F., and Desvillettes, L. (2017). Influence of dispersal processes on the global dynamics of emperor penguin, a species threatened by climate change. Biol. Conserv. 212, 63-73. doi: 10.1016/j.biocon. 2017.05.017

Jenouvrier, S., Holland, M., Iles, D., Labrousse, S., Landrum, L., Garnier, J., et al. (2019). The Paris Agreement objectives will likely halt future declines of emperor penguins. Glob. Change Biol. 26, 1170-1184. doi: 10.1111/gcb.14864

Jenouvrier, S., Holland, M., Stroeve, J., Barbraud, C., Weimerskirch, H., Serreze, M., et al. (2012). Effects of climate change on an emperor penguin population: analysis of coupled demographic and climate models. Glob. Change Biol. 18, 2756-2770. doi: 10.1111/j.1365-2486.2012.02744.x

Jenouvrier, S., Holland, M., Stroeve, J., Serreze, M., Barbraud, C., Weimerskirch, H., et al. (2014). Projected continent-wide declines of the emperor penguin under climate change. Nat. Clim. Change 4, 715-718. doi: 10.1038/nclimate 2280

Jiménez, S., Domingo, A., Brazeiro, A., Defeo, O., Wood, A. G., Froy, H., et al. (2016). Sex-related variation in the vulnerability of wandering albatrosses to pelagic longline fleets. Anim. Conserv. 19, 281-295. doi: 10.111/acv.12245

Jiménez, S., Xavier, J. C., Domingo, A., Brazeiro, A., Defeo, O., Viera, M., et al. (2017). Inter-specific niche partitioning and overlap in albatrosses and petrels: dietary divergence and the role of fishing discards. Mar. Biol. 164:174. doi: 10.1007/s00227-017-3205-y

Johansen, M. P., Prentice, E., Cresswell, T., and Howell, N. (2018). Initial data on adsorption of Cs and $\mathrm{Sr}$ to the surfaces of microplastics with biofilm. J. Environ. Radioact. 190, 130-133. doi: 10.1016/j.jenvrad.2018.05.001
Johnston, D. W. (2019). Unoccupied aircraft systems in marine science and conservation. Annu. Rev. Mar. Sci. 11, 439-463. doi: 10.1146/annurev-marine010318-095323

Jones, C. W., Risi, M. M., Cleeland, J., and Ryan, P. G. (2019). First evidence of mouse attacks on adult albatrosses and petrels breeding on sub-Antarctic Marion and Gough Islands. Polar Biol. 42, 619-623. doi: 10.1007/s00300-01802444-6

Jones, H. I., Gallagher, J. M., and Miller, G. D. (2002). Survey of south polar skuas (Catharacta maccormicki) for blood parasites in the Vestfold Hills region of Antarctica. J. Wildl. Dis. 38, 213-215.

Jones, M. G. W., and Ryan, P. G. (2010). Evidence of mouse attacks on albatross chicks on sub-Antarctic Marion Island. Antarct. Sci. 22, 39-42. doi: 10.1017/ S0954102009990459

Jouventin, P., and Weimerskirch, H. (1990). Satellite tracking of wandering albatrosses. Nature 343, 746-748.

Kahl, L. A., Schofield, O., and Fraser, W. R. (2010). Autonomous gliders reveal features of the water column associated with foraging by Adélie penguins. Integr. Comp. Biol. 50, 1041-1050. doi: 10.1093/icb/icq098

Kahru, M., Mitchell, B. G., Gille, S. T., Hewes, C. D., and Holm-Hansen, O. (2007). Eddies enhance biological production in the Weddell-Scotia confluence of the Southern Ocean. Geophys. Res. Lett. 34:L14603. doi: 10.1029/2007GL030430

Kawakami, T. (1980). A Review of Sperm Whale Food, Vol. 32. Tokyo: Reports of the Whales Research Institute, 199-218.

Kelly, N., Emmerson, L., Kawaguchi, S., Southwell, C., and Welsford, D. (2018). An Ecological Risk Assessment of Current Conservation Measures for Krill Fishing in East Antarctica (CCAMLR Divisions 58.4.1 and 58.4.2). WG-EMM-18/37. Available online at: https://www.ccamlr.org/en/wg-emm-18/37 (accessed June 25, 2018).

Kennedy, S., Kuiken, T., Jepson, P. D., Deaville, R., Forsyth, M., Barrett, T., et al. (2000). Mass die-off of Caspian seals caused by canine distemper virus. Emerg. Infect. Dis. 6, 637-639. doi: 10.3201/eid0606.000613

Keogan, K., Daunt, F., Wanless, S., Phillips, R. A., Walling, C. A., Agnew, P., et al. (2018). Global phenological insensitivity to shifting ocean temperatures among seabirds. Nat. Clim. Change 8, 313-318. doi: 10.1038/s41558-018-0115-z

Kerry, K. R., and Riddle, M. (2009). Health of Antarctic Wildlife: a Challenge for Science and Policy. Berlin: Springer, 349.

Kershaw, J. L., and Hall, A. J. (2019). Mercury in cetaceans: exposure, bioaccumulation and toxicity. Sci. Total Environ. 694:133683. doi: 10.1016/j. scitotenv.2019.133683

Kock, K.-H. (2007). Antarctic marine living resources - exploitation and its management in the Southern Ocean. Antarct. Sci. 19, 231-238. doi: 10.1017/ S0954102007000302

Kock, K.-H., Purves, M. G., and Duhamel, G. (2006). Interactions between cetacean and fisheries in the Southern Ocean. Polar Biol. 29, 379-388. doi: 10.1007/ s00300-005-0067-4

Kock, K.-H., Reid, K., Croxall, J., and Nicol, S. (2007). Fisheries in the Southern Ocean: an ecosystem approach. Philos. Trans. R. Soc. B Biol. Sci. 362, 23332349.

Kooyman, G. L., Ainley, D. G., Ballard, G., and Ponganis, P. J. (2007). Effects of giant icebergs on two emperor penguin colonies in the Ross Sea, Antarctica. Antarct. Sci. 19, 31-38. doi: 10.1017/S0954102007000065

Kranstauber, B., Cameron, A., Weinzerl, R., Fountain, T., Tilak, S., Wikelski, M., et al. (2011). The Movebank data model for animal tracking. Environ. Modell. Softw. 26, 834-835. doi: 10.1016/j.envsoft.2010.12.005

Krause, D. J., Goebel, M. E., Marshall, G. J., and Abernathy, K. (2015). Novel foraging strategies observed in a growing leopard seal (Hydrurga leptonyx) population at Livingston Island, Antarctic Peninsula. Anim. Biotelemetry 3:24. doi: 10.1186/s40317-015-0059-2

Krüger, L., Ramos, J. A., Xavier, J. C., Gremillet, D., González-Solís, J., Petry, M. V., et al. (2018). Projected distributions of Southern Ocean albatrosses, petrels and fisheries as a consequence of climatic change. Ecography 41, 195-208. doi: 10.1111/ecog.02590

Kühn, S., Rebolledo, E. L. B., and van Franeker, J. A. (2015). "Deleterious effects of litter on marine life," in Marine Anthropogenic Litter, eds M. Bergamnn, L. Gutow, and M. Klages (Cham: Springer), 75-116.

Labrousse, S., Fraser, A. D., Sumner, M., Tamura, T., Pinaud, D., Wienecke, B., et al. (2019). Dynamic fine-scale sea icescape shapes adult emperor penguin 
foraging habitat in East Antarctica. Geophys. Res. Lett. 46, 11206-11218. doi: 10.1029/2019GL084347

Lafferty, K. D., and Holt, R. D. (2003). How should environmental stress affect the population dynamics of disease? Ecol Lett. 6, 654-664. doi: 10.1046/j.1461-0248. 2003.00480.x

Laird, M. (1961). A lack of avian and mammalian haematozoa in the Antarctic and Canadian Arctic. Can. J. Zool. 39, 209-213.

LaRue, M. A., Ainley, D. G., Pennycook, J., Stamatiou, K., Salas, L., Nur, N., et al. (2019). Engaging 'the crowd' in remote sensing to learn about habitat affinity of the Weddell seal in Antarctica. Remote Sens. Ecol. Conserv. 6, 70-78. doi: $10.1002 /$ rse2.124

LaRue, M. A., and Knight, J. (2014). Applications of very high-resolution imagery in the study and conservation of large predators in the Southern Ocean. Conserv. Biol. 28, 1731-1735. doi: 10.1111/cobi.12367

Lascelles, B. G., Taylor, P. R., Miller, M. G. R., Dias, M. P., Oppel, S., Torres, L., et al. (2016). Applying global criteria to tracking data to define important areas for marine conservation. Divers. Distrib. 22, 422-431. doi: 10.1111/ddi.12411

Le Guen, C., Kato, A., Raymond, B., Barbraud, C., Beaulieu, M., Bost, C. A., et al. (2018). Reproductive performance and diving behaviour share a common sea-ice concentration optimum in Adélie penguins (Pygoscelis adeliae). Glob. Change Biol. 24, 5304-5317. doi: 10.1111/gcb.14377

Lehnert, K., Weirup, L., Harding, K. C., Härkönen, T., Karlsson, O., and Teilmann, J. (2017). Antarctic seals: molecular biomarkers as indicators for pollutant exposure, health effects and diet. Sci. Total Environ. 599, 1693-1704. doi: 10. 1016/j.scitotenv.2017.04.224

Leotta, G. A., Chinen, I., Vigo, G. B., Pecoraro, M., and Rivas, M. (2006). Outbreaks of avian cholera in Hope Bay, Antarctica. J. Wildl. Dis. 42, 259-270. doi: 10. 7589/0090-3558-42.2.259

Levy, H., Clucas, G. V., Rogers, A. D., Leaché, A. D., Ciborowski, K. L., Polito, M. J., et al. (2016). Population structure and phylogeography of the gentoo penguin (Pygoscelis papua) across the Scotia Arc. Ecol. Evol. 6, 1834-1853. doi: $10.1002 /$ ece3.1929

Lewis, P. N., Riddle, M. J., and Hewitt, C. L. (2004). Management of exogenous threats to Antarctica and the sub-Antarctic Islands: balancing risks from TBT and non-indigenous marine organisms. Mar. Pollut. Bull. 49, 999-1005.

Liggett, D., McIntosh, A., Thompson, A., Gilbert, N., and Storey, B. (2011). From frozen continent to tourism hotspot? Five decades of Antarctic tourism development and management, and a glimpse into the future. Tourism Manag. 32, 357-366. doi: 10.1016/j.tourman.2010.03.005

Ling, J. (1999). Elephant seal oil cargoes from King Island, Bass Strait, 1802-1819: with estimates of numbers killed and size of the original population. Pap. Proc. R. Soc. Tasmania 133, 51-56. doi: 10.26749/rstpp.133.1.51

Lowther, A. D., Lydersen, C., Biuw, M., de Bruyn, P. J. N., Hofmeyr, G. J. G., and Kovacs, K. M. (2014). Post-breeding at-sea movements of three centralplace foragers in relation to submesoscale fronts in the Southern Ocean around Bouvetøya. Antarct. Sci. 26, 533-544. doi: 10.1017/S0954102014000170

Lu, Z., De Silva, A. O., Provencher, J. F., Mallory, M. L., Kirk, J. L., Houde, M., et al. (2019). Occurrence of substituted diphenylamine antioxidants and benzotriazole UV stabilizers in Arctic seabirds and seals. Sci. Total Environ. 663, 950-957. doi: 10.1016/j.scitotenv.2019.01.354

Lübcker, N., Bloem, L. M., du Toit, T., Swart, P., de Bruyn, P. N., Swart, A. C., et al. (2020). What's in a whisker? High-throughput analysis of twenty-eight C19 and C21 steroids in mammalian whiskers by ultra-performance convergence chromatography-tandem mass spectrometry. J. Chromatogr. B 1141:122028. doi: 10.1016/j.jchromb.2020.122028

Lübcker, N., Reisinger, R. R., Oosthuizen, W. C., de Bruyn, P. N., van Tonder, A., Pistorius, P. A., et al. (2017). Low trophic level diet of juvenile southern elephant seals Mirounga leonina from Marion Island: a stable isotope investigation using vibrissal regrowths. Mar. Ecol. Prog. Ser. 577, 237-250. doi: 10.3354/meps 12240

Lynch, H. J., Fagan, W. F., Naveen, R., Trivelpiece, S. G., and Trivelpiece, W. Z. (2012). Differential advancement of breeding phenology in response to climate may alter staggered breeding among sympatric pygoscelid penguins. Mar. Ecol. Prog. Ser. 454, 135-145. doi: 10.3354/meps09252

Maner, J., Burkard, M., Cassano, J. C., Bengtson Nash, S. M., Schirmer, K., and Suter, M. J. F. (2019). Hexachlorobenzene exerts genotoxic effects in a humpback whale cell line under stable exposure conditions. RSC $A d v .9$, 39447-39457. doi: 10.1039/C9RA05352B
Massie, P. P., McIntyre, T., Ryan, P. G., Bester, M. N., Bornemann, H., and Ansorge, I. J. (2016). The role of eddies in the diving behaviour of female southern elephant seals. Polar Biol. 39, 297-307. doi: 10.1007/s00300-015-1782-0

Massom, R. A., Hill, K., Barbraud, C., Adams, N., Ancel, A., Emmerson, L., et al. (2009). Fast ice distribution in Adélie Land, East Antarctica: interannual variability and implications for emperor penguins Aptenodytes forsteri. Mar. Ecol. Prog. Ser. 374, 243-257. doi: 10.3354/meps07734

Massom, R. A., and Stammerjohn, S. E. (2010). Antarctic sea ice change and variability - physical and ecological implications. Polar Sci. 4, 149-186. doi: 10.1016/j.polar.2010.05.001

Matthewson, D. C., Van Aarde, R. J., and Skinner, J. D. (1994). Population biology of house mice (Mus musculus L.) on sub-Antarctic Marion Island. S. Afr. J. Zool. $29,99-106$.

McCallum, H., Harvell, D., and Dobson, A. (2003). Rates of spread of marine pathogens. Ecol. Lett. 6, 1062-1067. doi: 10.1046/j.1461-0248.2003.00545.x

McCarthy, A. J., Shaw, M. A., and Goodman, S. J. (2007). Pathogen evolution and disease emergence in carnivores. Proc. R. Soc. B Biol. Sci. 274, 3165-3174. doi: $10.1098 /$ rspb.2007.0884

McCormack, S., Melbourne-Thomas, J., Trebilco, R., Blanchard, J., and Constable, A. (2017). Simplification of Complex Ecological Networks - Species Aggregation in Antarctic Food Web Models, eds G. Syme, D. Hatton MacDonald, E. Fulton, and J. Piantadosi (Newcastle: Modelling and Simulation Society of Australia and New Zealand Inc), 264-270.

McFarlane, R. A., Norman, R. D. B., and Jones, H. I. (2009). "Diseases and parasites of Antarctic and Sub-Antarctic seals," in Health of Antarctic Wildlife, eds K. R. Kerry and M. Riddle (Berlin: Springer), 57-93.

McHogg, A. M., Meredith, M. P., Chambers, D. P., Abrahamsen, E. P., Hughes, C. W., and Morrison, A. K. (2015). Recent trends in the Southern Ocean eddy field. J. Geophys. Res. Oceans 120, 257-267. doi: 10.1002/2014JC010470

McInnes, J. C., Alderman, R., Deagle, B. E., Lea, M. A., Raymond, B., and Jarman, S. N. (2017a). Optimised scat collection protocols for dietary DNA metabarcoding in vertebrates. Methods Ecol. Evol. 8, 192-202. doi: 10.1111/ 2041-210X.12677

McInnes, J. C., Jarman, S. N., Lea, M. A., Raymond, B., Deagle, B. E., Phillips, R. A., et al. (2017b). DNA metabarcoding as a marine conservation and management tool: a circumpolar examination of fishery discards in the diet of threatened albatrosses. Front. Mar. Sci. 4:277. doi: 10.3389/fmars.2017. 00277

McIntyre, T., Ansorge, I. J., Bornemann, H., Plötz, J., Tosh, C. A., and Bester, M. N. (2011). Elephant seal dive behaviour is altered by ocean temperature: implications for climate change impacts on an ocean predator. Mar. Ecol. Prog. Ser. 441, 257-272. doi: 10.3354/meps09383

McMahon, C., van den Hoff, J., and Burton, H. (2005). Handling intensity and the short-and long-term survival of elephant seals: addressing and quantifying research effects on wild animals. Ambio 34, 426-429. doi: 10.1579/0044-744734.6.426

McMahon, C. R., and Burton, H. R. (2005). Climate change and seal survival: evidence for environmentally mediated changes in elephant seal, Mirounga leonina, pup survival. Proc. R. Soc. B Biol. Sci. 272, 923-928. doi: 10.1098/rspb. 2004.3038

McMahon, C. R., Harcourt, R., Bateson, P., and Hindell, M. A. (2012). Animal welfare and decision making in wildlife research. Biol. Conserv. 153, 254-256. doi: 10.1016/j.biocon.2012.05.004

Meijers, A. J., Meredith, M. P., Murphy, E. J., Chambers, D. P., Belchier, M., and Young, E. F. (2019). The role of ocean dynamics in king penguin range estimation. Nat. Clim. Change 9, 120-121. doi: 10.1038/s41558-018-0388-2

Meredith, M., Sommerkorn, M., Cassotta, S., Derksen, C., Ekaykin, A., Hollowed, A., et al. (2019). "Polar regions," in IPCC Special Report on the Ocean and Cryosphere in a Changing Climate, eds H.-O. Pörtner, D. C. Roberts, V. MassonDelmotte, P. Zhai, M. Tignor, E. Poloczanska, et al. (Geneva: Intergovernmental Panel on Climate Change), 1-173.

Merino, S., Barbosa, A., Moreno, J., and Potti, J. (1997). Absence of haematozoa in a wild chinstrap penguin Pygoscelis antarctica population. Polar Biol. 18, 227-228.

Meyer, B., Freier, U., Grimm, V., Groeneveld, J., Hunt, B. P., Kerwath, S., et al. (2017). The winter pack-ice zone provides a sheltered but food-poor habitat for larval Antarctic krill. Nat. Ecol. Evol. 1, 1853-1861. doi: 10.1038/s41559-0170368-3 
Mills, W. F., Xavier, J. C., Bearhop, S., Cherel, Y., Votier, S. C., Waluda, C. M., et al. (2020). Long-term trends in albatross diets in relation to prey availability and breeding success. Mar. Biol. 167:29. doi: 10.1007/s00227-019-3630-1

Monaghan, P., Metcalfe, N. B., and Torres, R. (2009). Oxidative stress as a mediator of life history trade-offs: mechanisms, measurements and interpretation. Ecol. Lett. 12, 75-92. doi: 10.1111/j.1461-0248.2008.01258.x

Montero, E., González, L. M., Chaparro, A., Benzal, J., Bertellotti, M., Masero, J. A., et al. (2016). First record of Babesia sp. in Antarctic penguins. Ticks Tick Borne Dis. 7, 498-501. doi: 10.1016/j.ttbdis.2016.02.006

Moore, J. K., and Abbott, M. R. (2000). Phytoplankton chlorophyll distributions and primary production in the Southern Ocean. J. Geophys. Res. Oceans 105, 28709-28722. doi: 10.1029/1999JC000043

Muller, C. G., Chilvers, B. L., Barker, Z., Barnsdale, K. P., Battley, P. F., French, R. K., et al. (2019). Aerial VHF tracking of wildlife using an unmanned aerial vehicle (UAV): comparing efficiency of yellow-eyed penguin (Megadyptes antipodes) nest location methods. Wildl. Res. 46, 145-153.

Murphy, E. J., Watkins, J. L., Trathan, P. N., Reid, K., Meredith, M. P., Thorpe, S. E., et al. (2007). Spatial and temporal operation of the Scotia Sea ecosystem: a review of large-scale links in a krill centred food web. Philos. Trans. R. Soc. B Biol. Sci. 362, 113-148. doi: 10.1098/rstb.2006.1957

Murphy, R. C. (1964). "Systematics and distribution of Antarctic petrels," in Biologie Antarctique, eds R. Carrick, M. Holdgate, and J. Prevost (Paris: Hermann), 349-358.

Murray, M. D., Smith, M. S. R., and Soucek, Z. (1965). Studies on the ectoparasites of seals and penguins. 2. The ecology of the louse Antarctophthirus ogmorhini enderlein on the weddell seal, Leptonychotes weddelli Lesson. Aust. J. Zool. 13, 761-772.

Nel, D., Lutjeharms, J., Pakhomov, E., Ansorge, I., Ryan, P., and Klages, N. (2001). Exploitation of mesoscale oceanographic features by grey-headed albatross Thalassarche chrysostoma in the southern Indian Ocean. Mar. Ecol. Prog. Ser. 217, 15-26. doi: 10.3354/meps 217015

Nel, D. C., and Nel, J. L. (1999). Marine debris and fishing gear associated with seabirds at sub-Antarctic Marion Island, 1997/97 and 1997/98: in relation to longline fishing activity. CCAMLR Sci. 6, 85-96.

Nevitt, G. A., Bergstrom, D. M., and Bonadonna, F. (2006). The potential role of ammonia as a signal molecule for procellariiform seabirds. Mar. Ecol. Prog. Ser. 315, 271-277. doi: 10.3354/meps315271

Newsome, S. D., Clementz, M. T., and Koch, P. L. (2010). Using stable isotope biogeochemistry to study marine mammal ecology. Mar. Mamm. Sci. 26, 509-572. doi: 10.1111/j.1748-7692.2009.00354.x

Nicol, S., Worby, A., and Leaper, R. (2008). Changes in the Antarctic sea ice ecosystem: potential effects on krill and baleen whales. Mar. Freshw. Res. 59, 361-382. doi: 10.1071/MF07161

Noad, M. J., Kniest, E., and Dunlop, R. A. (2019). Boom to bust? Implications for the continued rapid growth of the eastern Australian humpback whale population despite recovery. Popul. Ecol. 61, 198-209. doi: 10.1002/1438-390X. 1014

Nolan, C. P., Liddle, G. M., and Elliot, J. (2000). Interactions between killer whales (Orcinus orca) and sperm whales (Physeter macrocephalus) with a longline fishing vessel. Mar. Mamm. Sci. 16, 658-664. doi: 10.1111/j.1748-7692.2000. tb00961.x

Nowacek, D. P., Christiansen, F., Bejder, L., Goldbogen, J. A., and Friedlaender, A. S. (2016). Studying cetacean behaviour: new technological approaches and conservation applications. Anim. Behav. 120, 235-244. doi: 10.1016/j.anbehav. 2016.07.019

Nowak, M. M., Dziób, K., and Bogawski, P. (2019). Unmanned Aerial Vehicles (UAVs) in environmental biology: a review. Eur. J. Ecol. 4, 56-74. doi: 10.2478/ eje-2018-0012

Orgeret, F., Weimerskirch, H., and Bost, C. A. (2016). Early diving behaviour in juvenile penguins: improvement or selection processes. Biol. Lett. 12:20160490. doi: $10.1098 / \mathrm{rsbl} .2016 .0490$

Pacoureau, N., Delord, K., Jenouvrier, S., and Barbraud, C. (2019). Demographic and population responses of an apex predator to climate and its prey: a longterm study of south polar skuas. Ecol. Monogr. 89:e01388. doi: 10.1002/ecm. 1388

Pallin, L. J., Baker, C. S., Steel, D., Kellar, N. M., Robbins, J., Johnston, D. W., et al. (2018). High pregnancy rates in humpback whales (Megaptera novaeangliae) around the Western Antarctic Peninsula, evidence of a rapidly growing population. $R$. Soc. Open Sci. 5:180017. doi: 10.1098/rsos.18 0017

Pardo, D., Forcada, J., Wood, A. G., Tuck, G. N., Ireland, L., Pradel, R., et al. (2017). Additive effects of climate and fisheries drive ongoing declines in multiple albatross species. Proc. Natl. Acad. Sci. U.S.A. 114, E10829-E10837. doi: $10.1073 /$ pnas.1618819114

Parker, G. C., Black, A., Rexer-Huber, K., Sommer, E., and Cuthbert, R. J. (2016). Low population density and biology of an island population of house mice Mus musculus on South Georgia. Polar Biol. 39, 1175-1181. doi: 10.1007/s00300015-1831-8

Parkinson, C. L. (2019). A 40-y record reveals gradual Antarctic sea ice increases followed by decreases at rates far exceeding the rates seen in the Arctic. Proc. Natl. Acad. Sci. U.S.A. 116, 14414-14423. doi: 10.1073/pnas.1906556116

Patenaude, N. J., Portway, V. A., Schaeff, C. M., Bannister, J. L., Best, P., Payne, R. S., et al. (2007). Mitochondrial DNA diversity and population structure among southern right whales (Eubalaena australis). J. Hered. 98, 147-157. doi: 10.1093/jhered/esm005

Patz, J. A., Graczyk, T. K., Geller, N., and Vittor, A. Y. (2000). Effects of environmental change on emerging parasitic diseases. Int. J. Parasitol. 30, 1395-1405.

Peirce, M. A., and Prince, P. A. (1980). Hepatozoon albatrossi sp. nov. (Eucoccida: Hepatozoidae) from Diomedea spp. in the Antarctic. J. Nat. Hist. 14, 447-452. doi: 10.1016/S0020-7519(00)00141-7

Perissinotto, R., and McQuaid, C. D. (1992). Land-based predator impact on vertically migrating zooplankton and micronekton advected to a Southern Ocean Archipelago. Mar. Ecol. Prog. Ser. 80, 15-27.

Péron, C., Authier, M., Barbraud, C., Delord, K., Besson, D., and Weimerskirch, H. (2010). Interdecadal changes in at-sea distribution and abundance of subantarctic seabirds along a latitudinal gradient in the Southern Indian Ocean. Glob. Change Biol. 16, 1895-1909.

Péron, C., Weimerskirch, H., and Bost, C.-A. (2012). Projected poleward shift of king penguins' (Aptenodytes patagonicus) foraging range at the Crozet Islands, southern Indian Ocean. Proc. R. Soc. B Biol. Sci. 279, 2515-2523. doi: 10.1098/ rspb.2011.2705

Perrin, W. F., Mallette, S. D., and Brownell, R. L. Jr. (2018). "Minke whales: Balaenoptera acutorostrata and B. bonaerensis," in Encyclopedia of Marine Mammals, eds W. F. Perrin, B. Würsig, and J. G. M. Thewissen (New York, NY: Academic Press), 608-613.

Phillips, R. (2013). Requisite improvements to the estimation of seabird by-catch in pelagic longline fisheries. Anim. Conserv. 16, 157-158. doi: 10.1111/acv.12042

Phillips, R. A., Gales, R., Baker, G. B., Double, M. C., Favero, M., Quintana, F., et al. (2016). The conservation status and priorities for albatrosses and large petrels. Biol. Conserv. 201, 169-183. doi: 10.1016/j.biocon.2016.06.017

Phillips, R. A., Ridley, C., Reid, K., Pugh, P. J. A., Tuck, G. N., and Harrison, N. (2010). Ingestion of fishing gear and entanglements of seabirds: monitoring and implications for management. Biol. Conserv. 143, 501-512. doi: 10.1016/ j.biocon.2009.11.020

Phillips, R. A., and Waluda, C. M. (2020). Albatrosses and petrels at South Georgia as sentinels of marine debris input from vessels in the southwest Atlantic Ocean. Environ. Int. 136:105443. doi: 10.1016/j.envint.2019.105443

Pinkerton, M. H., and Bradford-Grieve, J. M. (2014). Characterizing foodweb structure to identify potential ecosystem effects of fishing in the Ross Sea, Antarctica. ICES J. Mar. Sci. 71, 1542-1553. doi: 10.1093/icesjms/fst230

Pitman, R. L. (2011). Whalewatcher: Journal of the American Cetacean Society, Vol. 40. Los Angeles, CA: American Cetacean Society.

Pitman, R. L., and Ensor, P. (2003). Three different forms of killer whales in Antarctic waters. J. Cetacean Res. Manag. 5, 131-139.

Pitman, R. L., Fearnbach, H., and Durban, J. W. (2018). Abundance and population status of Ross Sea killer whales (Orcinus orca, type C) in McMurdo Sound, Antarctica: evidence for impact by commercial fishing? Polar Biol. 41, 781-792. doi: 10.1007/s00300-017-2239-4

Polito, M. J., Brasso, R. L., Trivelpiece, W. Z., Karnovsky, N., Patterson, W. P., and Emslie, S. D. (2016). Differing foraging strategies influence mercury (Hg) exposure in an Antarctic penguin community. Environ. Pollut. 218, 196-206. doi: 10.1016/j.envpol.2016.04.097

Poncelet, É., Barbraud, C., and Guinet, C. (2010). Population dynamics of killer whales (Orcinus orca) in the Crozet Archipelago, southern Indian Ocean: a mark-recapture study from 1977 to 2002. J. Cetacean Res. Manag. 11, 41-48. 
Prellezo, R., and Maravelias, C. (2019). Exploring the economic viability of a mesopelagic fishery in the Bay of Biscay. ICES J. Mar. Sci. 76, 771-779. doi: 10.1093/icesjms/fsy001

Prevedouros, K., Cousins, I. T., Buck, R. C., and Korzeniowski, S. H. (2006). Sources, fate and transport of perfluorocarboxylates. Environ. Sci. Technol. 40, 32-44. doi: 10.1021/es0512475

Proffitt, K. M., Garrott, R. A., Rotella, J. J., Siniff, D. B., and Testa, J. W. (2007). Exploring linkages between abiotic oceanographic processes and a top-trophic predator in an Antarctic ecosystem. Ecosystems 10:120. doi: 10.1007/s10021006-9003- $\mathrm{x}$

Provencher, J. F., Ammendolia, J., Rochman, C. M., and Mallory, M. L. (2019). Assessing plastic debris in aquatic food webs: what we know and don't know about uptake and trophic transfer. Environ. Rev. 27, 304-317.

Pugh, P. J. A. (1993). A synonymic catalogue of the Acari from Antarctica, the sub-Antarctic Islands and the Southern Ocean. J. Nat. Hist. 27, 323-421.

Purves, M. G., and Agnew, D. J. (2004). Killer whale (Orcinus orca) and sperm whale (Physeter macrocephalus) interactions with longline vessels in the Patagonian toothfish fishery at South Georgia, South Atlantic. CCAMLR Sci. 11, 111-126.

Puskic, P. S., Lavers, J. L., Adams, L. R., and Bond, A. L. (2020). Ingested plastic and trace element concentrations in short-tailed shearwaters (Ardenna tenuirostris). Mar. Pollut. Bull. 155:111143. doi: 10.1016/j.marpolbul.2020.111143

Quillfeldt, P., Masello, J. F., McGill, R. A., Adams, M., and Furness, R. W. (2010). Moving polewards in winter: a recent change in the migratory strategy of a pelagic seabird? Front. Zool. 7:15. doi: 10.1186/1742-9994-7-15

Quillfeldt, P., Schenk, I., McGill, R. A., Strange, I. J., Masello, J. F., Gladbach, A., et al. (2008). Introduced mammals coexist with seabirds at New Island, Falkland Islands: abundance, habitat preferences, and stable isotope analysis of diet. Polar Biol. 31, 333-349. doi: 10.1007/s00300-007-0363-2

Ratcliffe, N., Hill, S. L., Staniland, I. J., Brown, R., Adlard, S., Horswill, C., et al. (2015). Do krill fisheries compete with macaroni penguins? Spatial overlap in prey consumption and catches during winter. Divers. Distrib. 21, 1339-1348. doi: $10.1111 /$ ddi.12366

Ratcliffe, N., and Trathan, P. N. (2011). A review of the diet and at-sea distribution of penguins breeding within the CAMLR convention area. CCAMLR Sci. 18, 75-114.

Rayfuse, R. (2018). Climate change and Antarctic fisheries: ecosystem management in CCAMLR. Ecol. Law Q. 45, 53-81. doi: 10.15779/Z381834271

Raymond, B., Marshall, M., Nevitt, G., Gillies, C. L., van den Hoff, J., Stark, J. S., et al. (2011). A Southern Ocean dietary database: ecological archives E092-097. Ecology 92:1188. doi: 10.1890/10-1907.1

Raymond, B., and Sumner, M. (2018). The Antarctic/Southern Ocean rOpenSci Community. Available online at: https://ropensci.org/blog/2018/11/13/ antarctic/ (accessed March 19, 2020).

Redfern, C. P., and Bevan, R. M. (2020). Use of sea ice by arctic terns Sterna paradisaea in Antarctica and impacts of climate change. J. Avian Biol. 51, 1-12. doi: $10.1111 /$ jav.02318

Reid, K., and Croxall, J. P. (2001). Environmental response of upper trophic-level predators reveals a system change in an Antarctic marine ecosystem. Proc. $R$. Soc. Lond. B Biol. Sci. 268, 377-384. doi: 10.1098/rspb.2000.1371

Reid, K., Croxall, J. P., Briggs, D. R., and Murphy, E. J. (2005). Antarctic ecosystem monitoring: quantifying the response of ecosystem indicators to variability in Antarctic krill. ICES J. Mar. Sci. 62, 366-373. doi: 10.1016/j.icesjms.2004. 11.003

Reisinger, R. R., Raymond, B., Hindell, M. A., Bester, M. N., Crawford, R. J., Davies, D., et al. (2018). Habitat modelling of tracking data from multiple marine predators identifies important areas in the Southern Indian Ocean. Divers. Distrib. 24, 535-550. doi: 10.1111/ddi.12702

Ribic, C. A., Ainley, D. G., and Fraser, W. R. (1991). Habitat selection by marine mammals in the marginal ice zone. Antarct. Sci. 3, 181-186.

Richard, G., Bonnel, J., Tixier, P., Arnould, J. P., Janc, A., and Guinet, C. (2020). Evidence of deep-sea interactions between toothed whales and longlines. Ambio 49, 173-186. doi: 10.1007/s13280-019-01182-1

Richard, H., Carpenter, E. J., Komada, T., Palmer, P. T., and Rochman, C. M. (2019). Biofilm facilitates metal accumulation onto microplastics in estuarine waters. Sci. Total Environ. 683, 600-608. doi: 10.1016/j.scitotenv.2019.04.331
Rintoul, S. R., Chown, S. L., DeConto, R. M., England, M. H., Fricker, H. A., Masson-Delmotte, V., et al. (2018). Choosing the future of Antarctica. Nature 558, 233-241. doi: 10.1038/s41586-018-0173-4

Risch, D., Norris, T., Curnock, M., and Friedlaender, A. (2019). Common and Antarctic minke whales: conservation status and future research directions. Front. Mar. Sci. 6:247. doi: 10.3389/fmars.2019.00247

Rivière, P., Jaud, T., Siegelman, L., Klein, P., Cotté, C., Le Sommer, J., et al. (2019). Sub-mesoscale fronts modify elephant seals foraging behavior. Limnol. Oceanogr. Lett. 4, 193-204. doi: 10.1002/lol2.10121

Rocha, R. C., Clapham, P. J., and Ivashchenko, Y. V. (2014). Emptying the oceans: a summary of industrial whaling catches in the 20th century. Mar. Fish. Rev. 76, 37-48. doi: 10.7755/MFR.76.4.3

Roche, C., Guinet, C., Gasco, N., and Duhamel, G. (2007). Marine mammals and demersal longline fishery interactions in Crozet and Kerguelen exclusive economic zones: an assessment of depredation levels. CCAMLR Sci. 14, 67-82.

Rodríguez, A., Arcos, J. M., Bretagnolle, V., Dias, M. P., Holmes, N. D., Louzao, M., et al. (2019). Future directions in conservation research on petrels and shearwaters. Front. Mar. Sci. 6:94. doi: 10.3389/fmars.2019.00094

Rogers, A. D., Frinault, B. A. V., Barnes, D. K. A., Bindoff, N. L., Downie, R., Ducklow, H. W., et al. (2020). Antarctic futures: an assessment of climatedriven changes in ecosystem structure, function, and service provisioning in the Southern Ocean. Annu. Rev. Mar. Sci. 12, 87-120. doi: 10.1146/annurevmarine-010419-011028

Rolland, V., Weimerskirch, H., and Barbraud, C. (2010). Relative influence of fisheries and climate on the demography of four albatross species. Glob. Change Biol. 16, 1910-1922.

Roman, L., Bell, E., Wilcox, C., Hardesty, B. D., and Hindell, M. (2019). Ecological drivers of marine debris ingestion in Procellariiform seabirds. Sci. Rep. 9:916. doi: 10.1038/s41598-018-37324-w

Ropert-Coudert, Y., Chiaradia, A., Ainley, D., Barbosa, A., Boersma, P. D., Brasso, R., et al. (2019). Happy feet in a hostile world? The future of penguins depends on proactive management of current and expected threats. Front. Mar. Sci. 6:248. doi: 10.3389/fmars.2019.00248

Ropert-Coudert, Y., Hindell, M. A., Phillips, R. A., Charrassin, J.-B., Trudelle, L., and Raymond, B. (2014). "Biogeographic patterns of birds and mammals," in Biogeographic Atlas of the Southern Ocean, eds C. De Broyer, P. Koubbi, H. J. Griffiths, B. Raymond, C. d'Udekem, C. d'Acoz, et al. (Cambridge: Scientific Committee on Antarctic Research), 364-387.

Ropert-Coudert, Y., Kato, A., Baudat, J., Bost, C. A., Le Maho, Y., and Naito, Y. (2001). Feeding strategies of free-ranging Adélie penguins Pygoscelis adeliae analysed by multiple data recording. Polar Biol. 24, 460-466. doi: 10.1007/ s003000100234

Ropert-Coudert, Y., Kato, A., Grémillet, D., and Crenner, F. (2012). "Biologging: recording the ecophysiology and behavior of animals moving freely in their environment," in Sensors for Ecology: Towards Integrated Knowledge of Ecosystems, eds J. F. Le Galliard, J. M. Guarini, and F. Gaill (Paris: Centre National de la Recherche Scientifique), 17-41.

Ropert-Coudert, Y., Kato, A., Meyer, X., Pellé, M., MacIntosh, A. J., Angelier, F., et al. (2015). A complete breeding failure in an Adélie penguin colony correlates with unusual and extreme environmental events. Ecography 38, 111-113. doi: 10.1111/ecog.01182

Ropert-Coudert, Y., Kato, A., Robbins, A., and Humphries, G. R. W. (2018a). The Penguiness Book. World Wide Web Electronic Publication. Available online at: http://www.penguiness.net (accessed October 2018).

Ropert-Coudert, Y., Kato, A., Shiomi, K., Barbraud, C., Angelier, F., Delord, K., et al. (2018b). Two recent massive breeding failures in an Adélie penguin colony call for the creation of a Marine Protected Area in d'Urville Sea/Mertz. Front. Mar. Sci. 5:264. doi: 10.3389/fmars.2018.00264

Ropert-Coudert, Y., Van de Putte, A. P., Reisinger, R. R., Bornemann, H., Charrassin, J. B., Costa, D. P., et al. (2020). The retrospective analysis of Antarctic tracking data project. Sci. Data 7:94. doi: 10.1038/s41597-020-0406-X

Ropert-Coudert, Y., and Wilson, R. P. (2005). Trends and perspectives in animalattached remote sensing. Front. Ecol. Environ. 3, 437-444.

Routti, H., Jenssen, B. M., and Tartu, S. (2018). "Ecotoxicologic stress in Arctic marine mammals, with particular focus on polar bears," in Marine Mammal Ecotoxicology, (New York, NY: Academic Press), 345-380. 
Rümmler, M. C., Mustafa, O., Maercker, J., Peter, H. U., and Esefeld, J. (2018). Sensitivity of Adélie and Gentoo penguins to various flight activities of a micro UAV. Polar Biol. 41, 2481-2493. doi: 10.1007/s00300-018-2385-3

Russ, R. (2007). History, exploration, settlement and past use of the sub-Antarctic. Pap. Proc. R. Soc. Tasmania 141, 169-172. doi: 10.26749/rstpp.141.1.169

Ryan, P. G. (2018). Entanglement of birds in plastics and other synthetic materials. Mar. Pollut. Bull. 135, 159-164. doi: 10.1016/j.marpolbul.2018. 06.057

Saba, G. K., Fraser, W. R., Saba, V. S., Iannuzzi, R. A., Coleman, K. E., Doney, S. C., et al. (2014). Winter and spring controls on the summer food web of the coastal West Antarctic Peninsula. Nat. Commun. 5:4318. doi: 10.1038/ncomms5318

Santa Cruz, F., Ernst, B., Arata, J. A., and Parada, C. (2018). Spatial and temporal dynamics of the Antarctic krill fishery in fishing hotspots in the Bransfield Strait and South Shetland Islands. Fish. Res. 208, 157-166. doi: 10.1016/j.fishres.2018. 07.020

Santora, J. A., Reiss, C. S., Loeb, V. J., and Veit, R. R. (2010). Spatial association between hotspots of baleen whales and demographic patterns of Antarctic krill Euphausia superba suggests size-dependent predation. Mar. Ecol. Prog. Ser. 405, 255-269. doi: 10.3354/meps 08513

Saunders, R. A., Hill, S. L., Tarling, G. A., and Murphy, E. J. (2019). Myctophid fish (Family Myctophidae) are central consumers in the food web of the scotia sea (Southern Ocean). Front. Mar. Sci. 6:530. doi: 10.3389/fmars.2019.00530

Savoca, M. S., Wohlfeil, M. E., Ebeler, S. E., and Nevitt, G. A. (2016). Marine plastic debris emits a keystone infochemical for olfactory foraging seabirds. Sci. Adv. 2:e1600395. doi: 10.1126/sciadv. 1600395

SC-CCAMLR (2016). Report of the 35th meeting of the Scientific Committee, Hobart, Australia 17-21 October. Available online at: https://www.ccamlr.org/ en/system/files/e-sc-xxxv.pdf (accessed October 16, 2020).

SC-CCAMLR (2018). Annex 8. Report of the Working Group on Ecosystem Monitoring and Management (WG-EMM). Available online at: https://www. ccamlr.org/en/system/files/e-sc-xxxvii_1.pdf (accessed October 16, 2020).

SC-CAMLR (2019). Annex 5. Report of the Working Group on Ecosystem Monitoring and Management (WG-EMM). Available online at: https://www. ccamlr.org/en/system/files/e-sc-38-rep_0.pdf (accessed October 16, 2020).

Scheffer, A., Trathan, P. N., Edmonston, J. G., and Bost, C. A. (2016). Combined influence of meso-scale circulation and bathymetry on the foraging behaviour of a diving predator, the king penguin (Aptenodytes patagonicus). Prog. Oceanogr. 141, 1-16. doi: 10.1016/j.pocean.2015.10.005

Schmidt, A. E., and Ballard, G. (2020). Significant chick loss after early fast ice breakup at a high-latitude emperor penguin colony. Antarct. Sci. 32, 180-185. doi: 10.1017/S0954102020000048

Schwartz, M. K., Luikart, G., and Waples, R. S. (2007). Genetic monitoring as a promising tool for conservation and management. Trends Ecol. Evol. 22, 25-33. doi: 10.1016/j.tree.2006.08.009

Scully, T. R. (1978). The marine living resources of the Southern Ocean. Univ. Miami Law Rev. 33, 341-356.

Seco, J., Xavier, J. C., Brierley, A. S., Bustamante, P., Coelho, J. P., Gregory, S., et al. (2020). Mercury levels in Southern Ocean squid: variability over the last decade. Chemosphere 239:124785. doi: 10.1016/j.chemosphere.2019.124785

Seyboth, E., Groch, K. R., Dalla Rosa, L., Reid, K., Flores, P. A., and Secchi, E. R. (2016). Southern right whale (Eubalaena australis) reproductive success is influenced by krill (Euphausia superba) density and climate. Sci. Rep. 6:28205. doi: $10.1038 /$ srep 28205

Shaw, J. D., Terauds, A., Riddle, M. J., Possingham, H. P., and Chown, S. L. (2014). Antarctica’s protected areas are inadequate, unrepresentative, and at risk. PLoS Biol. 12:e1001888. doi: 10.1371/journal.pbio. 1001888

Siegelman, L., O’Toole, M., Flexas, M., Rivière, P., and Klein, P. (2019). Submesoscale ocean fronts act as biological hotspot for southern elephant seal. Sci. Rep. 9:5588. doi: 10.1038/s41598-019-42117-w

Šimek, P., Pavlík, J., Jarolímek, J., Oèenášek, V., and Stoèes, M. (2017). "Use of unmanned aerial vehicles for wildlife monitoring," in Proceedings of the 8th International Conference on Information and Communication Technologies in Agriculture, Food and Environment (HAICTA 2017), 21-24 September 2017, Chania.

Siniff, D. B., Garrott, R. A., Rotella, J. J., Fraser, W. R., and Ainley, D. G. (2008). Projecting the effects of environmental change on Antarctic seals. Antarct. Sci. 20, 425-435. doi: 10.1017/S0954102008001351
Širović, A., Hildebrand, J. A., Wiggins, S. M., and Thiele, D. (2009). Blue and fin whale acoustic presence around Antarctica during 2003 and 2004. Mar. Mamm. Sci. 25, 125-136. doi: 10.1111/j.1748-7692.2008.00239.x

Smith, P., and McVeagh, M. (2000). Allozyme and microsatellite DNA markers of toothfish population structure in the Southern Ocean. J. Fish Biol. 57, 72-83. doi: 10.1111/j.1095-8649.2000.tb02245.x

Söffker, M., Trathan, P., Clark, J., Collins, M. A., Belchier, M., and Scott, R. (2015). The impact of predation by marine mammals on Patagonian toothfish longline fisheries. PLoS One 10:e0118113. doi: 10.1371/journal.pone.011 8113

Sokolov, S., and Rintoul, S. R. (2009). Circumpolar structure and distribution of the Antarctic Circumpolar Current fronts: 2. Variability and relationship to sea surface height. J. Geophys. Res. Oceans 114:C11019. doi: 10.1029/2008JC005248

Sontag, P. T., Steinberg, D. K., and Reinfelder, J. R. (2019). Patterns of total mercury and methylmercury bioaccumulation in Antarctic krill (Euphausia superba) along the West Antarctic Peninsula. Sci. Total Environ. 688, 174-183. doi: 10.1016/j.scitotenv.2019.06.176

Southwell, C., Bengtson, J., and Bester, M. (2012). A review of data on abundance, trends in abundance, habitat use and diet of ice-breeding seals in the Southern Ocean. CCAMLR Sci. 19, 49-74.

Southwell, C., and Emmerson, L. (2015). Remotely-operating camera network expands Antarctic seabird observations of key breeding parameters for ecosystem monitoring and management. J. Nat. Conserv. 23, 1-8. doi: 10.1016/ j.jnc.2014.11.002

Southwell, C., Emmerson, L., McKinlay, J., Newbery, K., Takahashi, A., Kato, A., et al. (2015). Spatially extensive standardized surveys reveal widespread, multi-decadal increase in East Antarctic Adélie penguin populations. PLoS One 10:e0139877. doi: 10.1371/journal.pone.0139877

Southwell, C., Mare, B. D. L., Borchers, D., and Burt, L. (2004). Shipboard line transect surveys of crabeater seal abundance in the pack-ice off East Antarctica: evaluation of assumptions. Mar. Mamm. Sci. 20, 602-620. doi: 10.111/j.174876922004.tb01182.x

Springer, K. (2018). "Eradication of invasive species on Macquarie Island to restore the natural ecosystem," in Recovering Australian Threatened Species: a Book of Hope, eds S. Garnett, P. Latch, D. Lindenmayer, and J. Woinarski (Melbourne: CSIRO Publishing), 13-22.

St John, M. A., Borja, A., Chust, G., Heath, M., Grigorov, I., Mariani, P., et al. (2016). A dark hole in our understanding of marine ecosystems and their services: perspectives from the mesopelagic community. Front. Mar. Sci. 3:31. doi: 10.3389/fmars.2016.00031

Stonehouse, B. (1952). Breeding behaviour of the emperor penguin. Nature 169:760.

Stroeve, J. C., Jenouvrier, S., Campbell, G. G., Barbraud, C., and Delord, K. (2016). Mapping and assessing variability in the Antarctic marginal ice zone, pack ice and coastal polynyas in two sea ice algorithms with implications on breeding success of snow petrels. Cryosphere 10, 1823-1843. doi: 10.5194/tc-10-18232016

Sydeman, J. W., Poloczanska, E., Reed, T. E., and Thompson, S. A. (2015). Climate change and marine vertebrates. Science 350, 772-777. doi: 10.1126/science. aac9874

Tanaka, K., Takada, H., Yamashita, R., Mizukawa, K., Fukuwaka, M. A., and Watanuki, Y. (2013). Accumulation of plastic-derived chemicals in tissues of seabirds ingesting marine plastics. Mar. Pollut. Bull. 69, 219-222. doi: 10.1016/ j.marpolbul.2012.12.010

Tanaka, K., Takada, H., Yamashita, R., Mizukawa, K., Fukuwaka, M. A., and Watanuki, Y. (2015). Facilitated leaching of additive-derived PBDEs from plastic by seabirds' stomach oil and accumulation in tissues. Environ. Sci. Technol. 49, 11799-11807. doi: 10.1021/acs.est.5b01376

Tarszisz, E., Dickman, C. R., and Munn, A. J. (2014). Physiology in conservation translocations. Conserv. Physiol. 2:cou054. doi: 10.1093/conphys/cou054

Tartu, S., Angelier, F., Wingfield, J. C., Bustamante, P., Labadie, P., Budzinski, H., et al. (2015). Corticosterone, prolactin and egg neglect behavior in relation to mercury and legacy POPs in a long-lived Antarctic bird. Sci. Total Environ. 505, 180-188. doi: 10.1016/j.scitotenv.2014.10.008

Tavares, D. C., de Moura, J. F., Merico, A., and Siciliano, S. (2017). Incidence of marine debris in seabirds feeding at different water depths. Mar. Pollut. Bull. 119, 68-73. doi: 10.1016/j.marpolbul.2017.04.012 
Taylor, R. H. (1979). How the Macquarie Island parakeet became extinct. N. Z. J. Ecol. 2, 42-45.

Thiebot, J. B., Arnould, J. P., Gómez-Laich, A., Ito, K., Kato, A., Mattern, T., et al. (2017). Jellyfish and other gelata as food for four penguin species-insights from predator-borne videos. Front. Ecol. Environ. 15, 437-441. doi: 10.1002/fee.1529

Thomas, P. O., Reeves, R. R., and Brownell, R. L. Jr. (2016). Status of the world's baleen whales. Mar. Mamm. Sci. 32, 682-734. doi: 10.1111/mms.12281

Tin, T., Lamers, M., Liggett, D., Maher, P. T., and Hughes, K. A. (2014). "Setting the scene: human activities, environmental impacts and governance arrangements in Antarctica," in Antarctic Futures, eds T. Tin, D. Liggett, P. T. Maher, and M. Lamers (Dordrecht: Springer), 1-24.

Tittensor, D. P., Beger, M., Boerder, K., Boyce, D. G., Cavanagh, R. D., CosandeyGodin, A., et al. (2019). Integrating climate adaptation and biodiversity conservation in the global ocean. Sci. Adv. 5:eaay9969. doi: 10.1126/sciadv. aay 9969

Tixier, P., Authier, M., Gasco, N., and Guinet, C. (2015). Influence of artificial food provisioning from fisheries on killer whale reproductive output. Anim. Conserv. 18, 207-218. doi: 10.1111/acv.12161

Tixier, P., Barbraud, C., Pardo, D., Gasco, N., Duhamel, G., and Guinet, C. (2017). Demographic consequences of fisheries interaction within a killer whale (Orcinus orca) population. Mar. Biol. 164:170. doi: 10.1007/s00227-017-3195-9

Tixier, P., Burch, P., Massiot-Granier, F., Ziegler, P., Welsford, D., Lea, M. A., et al. (2020). Assessing the impact of toothed whale depredation on socio-ecosystems and fishery management in wide-ranging subantarctic fisheries. Rev. Fish Biol. Fish. 30, 203-217. doi: 10.1007/s11160-020-09597-w

Tixier, P., Burch, P., Richard, G., Olsson, K., Welsford, D., Lea, M. A., et al. (2019a). Commercial fishing patterns influence odontocete whale-longline interactions in the Southern Ocean. Sci. Rep. 9:1904. doi: 10.1038/s41598-018-36389-x

Tixier, P., Giménez, J., Reisinger, R. R., Méndez-Fernandez, P., Arnould, J. P. Y., Cherel, Y., et al. (2019b). Importance of toothfish in the diet of generalist subantarctic killer whales: implications for fisheries interactions. Mar. Ecol. Prog. Ser. 613, 197-210. doi: 10.3354/meps12894

Tixier, P., Welsford, D., Hindell, M. A., Guinet, C., Janc, A., et al. (2019c). "Fisheries interaction data suggest variations in the distribution of sperm whales on the Kerguelen Plateau," in The Kerguelen Plateau: Marine Ecosystem and Fisheries, eds D. Welsford, J. Dell, and G. Duhamel (Kingston: Australian Antarctic Divisio), 259-270.

Tixier, P., Gasco, N., Duhamel, G., and Guinet, C. (2016). Depredation of Patagonian toothfish (Dissostichus eleginoides) by two sympatrically occurring killer whale (Orcinus orca) ecotypes: insights on the behavior of the rarely observed type D killer whales. Mar. Mamm. Sci. 32, 983-1003. doi: 10.1111/ mms. 12307

Torres, L. G., Nieukirk, S. L., Lemos, L., and Chandler, T. E. (2018). Drone up! Quantifying whale behavior from a new perspective improves observational capacity. Front. Mar. Sci. 5:319. doi: 10.3389/fmars.2018.00319

Torres, L. G., Smith, T. D., Sutton, P., Macdiarmid, A., Bannister, J., and Miyashita, T. (2013). From exploitation to conservation: habitat models using whaling data predict distribution patterns and threat exposure of an endangered whale. Divers. Distrib. 19, 1138-1152. doi: 10.1111/ddi.12069

Tosh, C. A., de Bruyn, P. N., Steyn, J., Bornemann, H., van den Hoff, J., Stewart, B. S., et al. (2015). The importance of seasonal sea surface height anomalies for foraging juvenile southern elephant seals. Mar. Biol. 162, 2131-2140.

Tow, L. A., and Cowan, D. A. (2005). Dissemination and survival of non-indigenous bacterial genomes in pristine Antarctic environments. Extremophiles 9, 385-389. doi: 10.1007/s00792-005-0452-5

Towers, J. R., Tixier, P., Ross, K. A., Bennett, J., Arnould, J. P., Pitman, R. L., et al. (2019). Movements and dive behaviour of a toothfish-depredating killer and sperm whale. ICES J. Mar. Sci. 76, 298-311. doi: 10.1093/icesjms/fsyl18

Trathan, P. N., Collins, M. A., Grant, S. M., Belchier, M., Barnes, D. K., Brown, J., et al. (2014). The South Georgia and the South Sandwich Islands MPA: protecting a biodiverse oceanic island chain situated in the flow of the Antarctic Circumpolar Current. Adv. Mar. Biol. 69, 15-78. doi: 10.1016/B978-0-12800214-8.00002-5

Trathan, P. N., García-Borboroglu, P., Boersma, D., Bost, C. A., Crawford, R. J., Crossin, G. T., et al. (2015). Pollution, habitat loss, fishing, and climate change as critical threats to penguins. Conserv. Biol. 29, 31-41. doi: 10.1111/cobi. 12349
Trathan, P. N., and Grant, S. M. (2020). "The South Orkney Islands Southern shelf marine protected area," in Marine Protected Areas, eds J. Humphreys and R. W. E. Clarke (Portsmouth: University of Portsmouth), 67-98.

Trathan, P. N., and Hill, S. L. (2016). "The importance of krill predation in the Southern Ocean," in Biology and Ecology of Antarctic Krill, ed. V. Siegel (Berlin: Springer), 321-350.

Trathan, P. N., and Reid, K. (2009). Exploitation of the marine ecosystem in the sub-Antarctic: historical impacts and current consequences. Pap. Proc. R. Soc. Tasmania 143, 9-14. doi: 10.26749/rstpp.143.1.9

Trathan, P. N., Warwick-Evans, V., and Young, E. (2019). Considerations about Managing the Krill Fishery at Small Spatial and Temporal Scales. WG-EMM2019/22. Available online at: https://www.ccamlr.org/en/wg-emm-2019/22? destination=node/105203 (accessed June 11, 2019).

Trathan, P. N., Wienecke, B., Barbraud, C., Jenouvrier, S., Kooyman, G., Le Bohec, C., et al. (2020). The emperor penguin - vulnerable to projected rates of warming and sea ice loss. Biol. Conserv. 241:108216. doi: 10.1016/j.biocon.2019. 108216

Treasure, A. M., Roquet, F., Ansorge, I. J., Bester, M. N., Boehme, L., Bornemann, H., et al. (2017). Marine mammals exploring the oceans pole to pole: a review of the MEOP consortium. Oceanography 30, 132-138. doi: 10.5670/oceanog.2017. 234

Trivelpiece, W. Z., Hinke, J. T., Miller, A. K., Reiss, C. S., Trivelpiece, S. G., and Watters, G. M. (2011). Variability in krill biomass links harvesting and climate warming to penguin population changes in Antarctica. Proc. Natl. Acad. Sci. U.S.A. 108, 7625-7628. doi: 10.1073/pnas. 1016560108

Tuck, G. N., Polacheck, T., and Bulman, C. M. (2003). Spatio-temporal trends of longline fishing effort in the Southern Ocean and implications for seabird bycatch. Biol. Conserv. 114, 1-27.

Tulloch, V. J., Plagányi, É. E., Brown, C., Richardson, A. J., and Matear, R. (2019). Future recovery of baleen whales is imperiled by climate change. Glob. Change Biol. 25, 1263-1281. doi: 10.1111/gcb.14573

Tulloch, V. J., Plagányi, É. E., Matear, R., Brown, C. J., and Richardson, A. J. (2018). Ecosystem modelling to quantify the impact of historical whaling on Southern Hemisphere baleen whales. Fish Fish. 19, 117-137. doi: 10.1111/faf.12241

Turner, J., Barrand, N. E., Bracegirdle, T. J., Convey, P., Hodgson, D. A., Jarvis, M., et al. (2013). Antarctic climate change and the environment: an update. Polar Rec. 50, 237-259. doi: 10.1017/S0032247413000296

Twiss, J. R. Jr., Hofman, R. J., and Baur, D. C. (1985). Annual Report of the Marine Mammal Commission, Calendar Year 1984 - A Report to Congress. Washington, DC: The Commission.

Tynan, C. T. (1998). Ecological importance of the southern boundary of the Antarctic Circumpolar Current. Nature 392, 708-710.

van den Hoff, J., Kilpatrick, R., and Welsford, D. (2017). Southern elephant seals (Mirounga leonina Linn.) depredate toothfish longlines in the midnight zone. PLoS One 12:e0172396. doi: 10.1371/journal.pone.0172396

van den Hoff, J., McMahon, C. R., Simpkins, G. R., Hindell, M. A., Alderman, R., and Burton, H. R. (2014). Bottom-up regulation of a pole-ward migratory predator population. Proc. R. Soc. B Biol. Sci. 281:20132842.

Van Hemert, C., Pearce, J. M., and Handel, C. M. (2014). Wildlife health in a rapidly changing North: focus on avian disease. Front. Ecol. Environ. 12, 548-556. doi: 10.1890/130291

van Polanen Petel, T. D., Terhune, J. M., Hindell, M. A., and Giese, M. A. (2006). An assessment of the audibility of sound from human transport by breeding Weddell seals (Leptonychotes weddellii). Wildl. Res. 33, 275-291. doi: 10.1071/ WR05001

VanWormer, E., Mazet, J. A. K., Hall, A., Gill, V. A., Boveng, P. L., London, J. M., et al. (2019). Viral emergence in marine mammals in the North Pacific may be linked to Arctic sea ice reduction. Sci. Rep. 9:15569. doi: 10.1038/s41598-01951699-4

Voyles, J., Kilpatrick, A. M., Collins, J. P., Fisher, M. C., Frick, W. F., McCallum, H., et al. (2015). Moving beyond too little, too late: managing emerging infectious diseases in wild populations requires international policy and partnerships. EcoHealth 12, 404-407.

Walsh, J., Reiss, C. S., and Watters, G. M. (2020). Flexibility in Antarctic krill Euphausia superba decouples diet and recruitment from overwinter sea-ice conditions in the northern Antarctic Peninsula. Mar. Ecol. Prog. Ser. 642, 1-19. doi: 10.3354/meps13325 
Walton, D. (2012). Keeping the aliens out. Antarct. Sci. 24:321. doi: 10.1017/ S0954102012000594

Waluda, C. M., Hill, S. L., Peat, H. J., and Trathan, P. N. (2012). Diet variability and reproductive performance of macaroni penguins Eudyptes chrysolophus at Bird Island, South Georgia. Mar. Ecol. Prog. Ser. 466, 261-274. doi: 10.3354/ meps09930

Waluda, C. M., Hill, S. L., Peat, H. J., and Trathan, P. N. (2017). Long-term variability in the diet and reproductive performance of penguins at Bird Island, South Georgia. Mar. Biol. 164:39. doi: 10.1007/s00227-016-3067-8

Wania, F., and Mackay, D. (1993). Global fractionation and cold condensation of low volatility organochlorine compounds in polar regions. Ambio 22, 10-18.

Wanless, R. M., Angel, A., Cuthbert, R. J., Hilton, G. M., and Ryan, P. G. (2007) Can predation by invasive mice drive seabird extinctions? Biol. Lett. 3, 241-244. doi: 10.1098/rsbl.2007.0120

Wanless, R. M., Ryan, P. G., Altwegg, R., Angel, A., Cooper, J., Cuthbert, R., et al. (2009). From both sides: dire demographic consequences of carnivorous mice and longlining for the critically endangered Tristan albatrosses on Gough Island. Biol. Conserv. 142, 1710-1718. doi: 10.1016/j.biocon.2009.03.008

Warwick-Evans, V., Dalla Rosa, L., Secchi, E., Seyboth, E., Kelly, N., and Trathan, P. N. (2019a). Developing Layers for a Risk Assessment for Subarea 48.1 Using Data from At-Sea Sightings. WG-EMM-2019/23. Hobart: CCAMLR.

Warwick-Evans, V., Friedlaender, A., Hinke, J. T., Kokubun, N., Kim, J. H., and Trathan, P. N. (2019b). Developing a Risk Assessment for Subarea 48.1 Using Tracking Data. WG-EMM-2019/24. Hobart: CCAMLR.

Watters, G. M., Hinke, J. T., and Reiss, C. S. (2020). Long-term observations from Antarctica demonstrate that mismatched scales of fisheries management and predator-prey interaction lead to erroneous conclusions about precaution. Sci. Rep. 10:2314. doi: 10.1038/s41598-020-59223-9

Wauchope, H. S., Shaw, J. D., and Terauds, A. (2019). A snapshot of biodiversity protection in Antarctica. Nat. Commun. 10:946. doi: 10.1038/s41467-01908915-6

Waugh, C. A., Nichols, P. D., Schlabach, M., Noad, M., and Bengtson Nash, S. (2014). Vertical distribution of lipids, fatty acids and organochlorine contaminants in the blubber of southern hemisphere humpback whales (Megaptera novaeangliae). Mar. Environ. Res. 94, 24-31. doi: 10.1016/j. marenvres.2013.11.004

Wege, M., de Bruyn, P. J. N., Hindell, M. A., Lea, M. A., and Bester, M. N. (2019). Preferred, small-scale foraging areas of two Southern Ocean fur seal species are not determined by habitat characteristics. BMC Ecol. 19:36. doi: 10.1186/ s12898-019-0252-x

Wege, M., Etienne, M. P., Chris Oosthuizen, W., Reisinger, R. R., Bester, M. N., and de Bruyn, P. N. (2016a). Trend changes in sympatric Subantarctic and Antarctic fur seal pup populations at Marion Island, Southern Ocean. Mar. Mamm. Sci. 32, 960-982. doi: 10.1111/mms.12306

Wege, M., Tosh, C. A., de Bruyn, P. J. N., and Bester, M. N. (2016b). Crossseasonal foraging site fidelity of subantarctic fur seals: implications for marine conservation areas. Mar. Ecol. Prog. Ser. 554, 225-239. doi: 10.3354/meps1 1798

Weimerskirch, H., Louzao, M., de Grissac, S., and Delord, K. (2012). Changes in wind pattern alter albatross distribution and life-history traits. Science 335, 211-214. doi: 10.1126/science. 1210270

Weimerskirch, H., Prudor, A., and Schull, Q. (2018). Flights of drones over sub-Antarctic seabirds show species-and status-specific behavioural and physiological responses. Polar Biol. 41, 259--266. doi: 10.1007/s00300-0172187-z

Weinstein, B. G., Double, M., Gales, N., Johnston, D. W., and Friedlaender, A. S. (2017). Identifying overlap between humpback whale foraging grounds and the Antarctic krill fishery. Biol. Conserv. 210, 184-191. doi: 10.1016/j.biocon.2017. 04.014

Wild, S., McLagan, D., Schlabach, M., Bossi, R., Hawker, D., Cropp, R., et al. (2015). An Antarctic research station as a source of brominated and perfluorinated persistent organic pollutants to the local environment. Environ. Sci. Technol. 49, 103-112. doi: 10.1021/es5048232
Wille, M., Harvey, E., Shi, M., Gonzalez-Acuña, D., Holmes, E. C., and Hurt, A. C. (2020). Sustained RNA virome diversity in Antarctic penguins and their ticks. ISME J. 14, 1768-1782. doi: 10.1038/s41396-0200643-1

Williams, R., Kelly, N., Boebel, O., Friedlaender, A. S., Herr, H., Kock, K. H., et al. (2014). Counting whales in a challenging, changing environment. Sci. Rep. 4:4170. doi: 10.1038/srep04170

Wilson, R. P. (1984). An improved stomach pump for penguins and other seabirds. J. Field Ornithol. 55, 109-112.

Wilson, R. P., and Culik, B. M. (1991). The cost of a hot meal: facultative specific dynamic action may ensure temperature homeostasis in post-ingestive endotherms. Comp. Biochem. Physiol. A 100, 151-154.

Wilson, R. P., and McMahon, C. R. (2006). Measuring devices on wild animals: what constitutes acceptable practice? Front. Ecol. Environ. 4, 147-154.

Wilson, R. P., Ropert-Coudert, Y., and Kato, A. (2002a). Rush and grab strategies in foraging marine endotherms: the case for haste in penguins. Anim. Behav. 63, 85-95. doi: 10.1006/anbe.2001.1883

Wilson, R. P., Steinfurth, A., Ropert-Coudert, Y., Kato, A., and Kurita, M. (2002b). Lip-reading in remote subjects: an attempt to quantify and separate ingestion, breathing and vocalisation in free-living animals using penguins as a model. Mar. Biol. 140, 17-27. doi: 10.1007/s002270100659

Wingfield, J. C., Maney, D. L., Breuner, C. W., Jacobs, J. D., Lynn, S., Ramenofsky, M., et al. (1998). Ecological bases of hormone-behavior interactions: the “emergency life history stage". Am. Zool. 38, 191-206.

Woehler, E. J., Ainley, D., and Jabour, J. (2014). "Human impacts to Antarctic wildlife: predictions and speculations for 2060," in Antarctic Futures, eds T. Tin, D. Liggett, P. T. Maher, and M. Lamers (Dordrecht: Springer), 27-60.

Yamashita, N., Taniyasu, S., Petrick, G., Wei, S., Gamo, T., Lam, P. K., et al. (2008). Perfluorinated acids as novel chemical tracers of global circulation of ocean waters. Chemosphere 70, 1247-1255. doi: 10.1016/j.chemosphere.2007.07.079

Yoda, K., Naito, Y., Sato, K., Takahashi, A., Nishikawa, J., Ropert-Coudert, Y., et al. (2001). A new technique for monitoring the behaviour of free-ranging Adélie penguins. Exp. Biol. 204, 685-690.

Younger, J. L., van den Hoff, J., Wienecke, B., Hindell, M., and Miller, K. J. (2016). Contrasting responses to a climate regime change by sympatric, ice-dependent predators. BMC Evol. Biol. 16:61. doi: 10.1186/s12862-016-0630-3

Yukhov, V. L. (1972). The range of fish of the genus Dissostichus (Fam. Nototheniidae) in Antarctic waters of the Indian Ocean. J. Ichthyol. 12, 346-347.

Zerbini, A. N., Adams, G., Best, J., Clapham, P. J., Jackson, J. A., and Punt, A. E. (2019). Assessing the recovery of an Antarctic predator from historical exploitation. R. Soc. Open Sci. 6:190368. doi: 10.1098/rsos.190368

Zwally, H. J., Comiso, J. C., Parkinson, C. L., Cavalieri, D. J., and Gloersen, P. (2002). Variability of Antarctic sea ice 1979-1998. J. Geophys. Res. Oceans 107, 9-1-9-19. doi: 10.1029/2000JC000733

Conflict of Interest: The authors declare that the research was conducted in the absence of any commercial or financial relationships that could be construed as a potential conflict of interest.

The handling editor declared a past co-authorship with one of the authors, SB.

Copyright (C) 2020 Bestley, Ropert-Coudert, Bengtson Nash, Brooks, Cotté, Dewar, Friedlaender, Jackson, Labrousse, Lowther, McMahon, Phillips, Pistorius, Puskic, Reis, Reisinger, Santos, Tarszisz, Tixier, Trathan, Wege and Wienecke. This is an open-access article distributed under the terms of the Creative Commons Attribution License (CC BY). The use, distribution or reproduction in other forums is permitted, provided the original author(s) and the copyright owner(s) are credited and that the original publication in this journal is cited, in accordance with accepted academic practice. No use, distribution or reproduction is permitted which does not comply with these terms. 